Prepared for the U.S. Department of Energy

under Contract DE-AC05-76RL01830

\title{
Radionuclide Retention in Concrete Wasteforms - FY13
}

\author{
MMV Snyder \\ EC Golovich \\ DM Wellman \\ JV Crum \\ R Lapierre \\ D Dage \\ KE Parker \\ E Cordova
}

October 2013

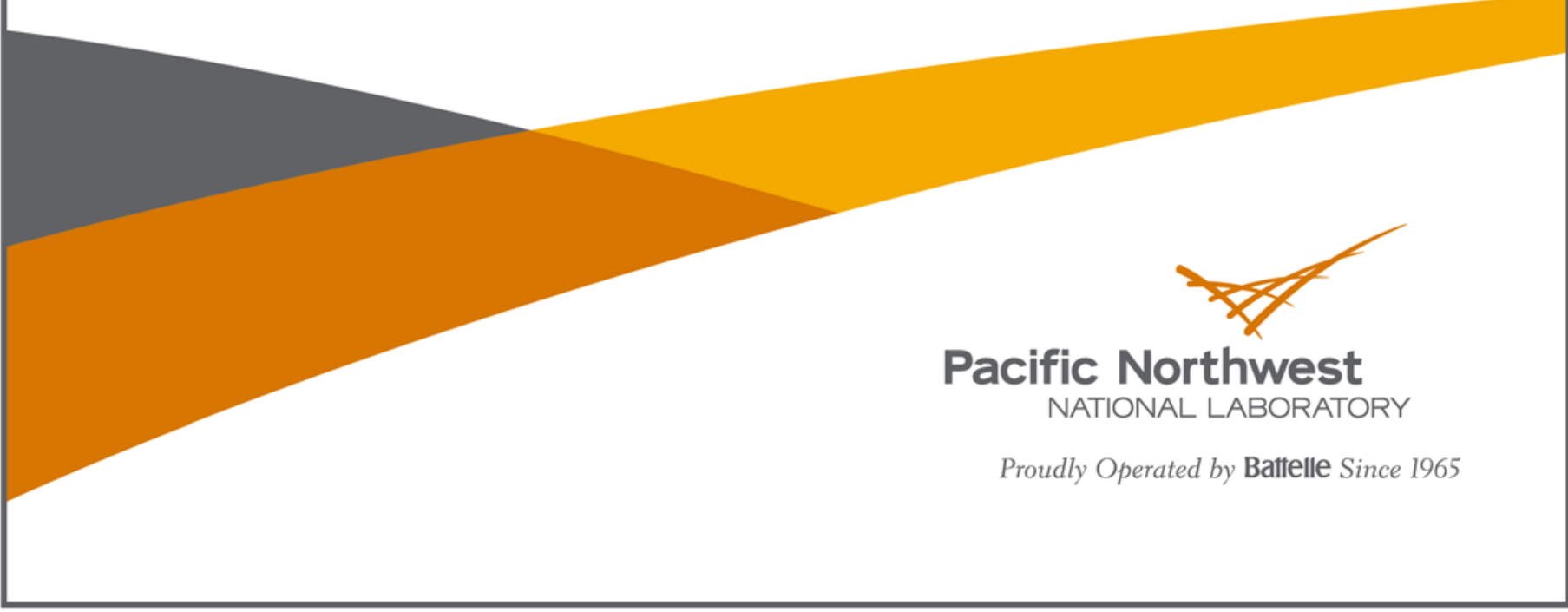




\title{
DISCLAIMER
}

This report was prepared as an account of work sponsored by an agency of the United States Government. Neither the United States Government nor any agency thereof, nor Battelle Memorial Institute, nor any of their employees, makes any warranty, express or implied, or assumes any legal liability or responsibility for the accuracy, completeness, or usefulness of any information, apparatus, product, or process disclosed, or represents that its use would not infringe privately owned rights. Reference herein to any specific commercial product, process, or service by trade name, trademark, manufacturer, or otherwise does not necessarily constitute or imply its endorsement, recommendation, or favoring by the United States Government or any agency thereof, or Battelle Memorial Institute. The views and opinions of authors expressed herein do not necessarily state or reflect those of the United States Government or any agency thereof.

\author{
PACIFIC NORTHWEST NATIONAL LABORATORY \\ operated by \\ BATTELLE \\ for the \\ UNITED STATES DEPARTMENT OF ENERGY \\ under Contract DE-AC05-76RL01830
}

Printed in the United States of America

Available to DOE and DOE contractors from the Office of Scientific and Technical Information, P.O. Box 62, Oak Ridge, TN 37831-0062; ph: (865) 576-8401 fax: $(\mathbf{8 6 5}) \mathbf{5 7 6}-\mathbf{5 7 2 8}$

email: reports $a$ adonis.osti.gov

Available to the public from the National Technical Information Service 5301 Shawnee Rd., Alexandria, VA 22312 ph: (800) 553-NTIS (6847)

email: orders@ntis.gov <http://www.ntis.gov/about/form.aspx > Online ordering: http:/www.ntis.gov 


\title{
Radionuclide Retention in Concrete Wasteforms - FY13
}

\author{
MMV Snyder \\ EC Golovich \\ DM Wellman \\ JV Crum \\ R Lapierre \\ D Dage \\ KE Parker \\ E Cordova
}

October 2013

Prepared for

the U.S. Department of Energy

under Contract DE-AC05-76RL01830

Pacific Northwest National Laboratory

Richland, Washington 99352 



\section{Summary}

Assessing long-term performance of Category 3 waste cement grouts for radionuclide encasement requires knowledge of the radionuclide-cement interactions and mechanisms of retention (i.e., sorption or precipitation); the mechanism of contaminant release; the significance of contaminant release pathways; how wasteform performance is affected by the full range of environmental conditions within the disposal facility; the process of wasteform aging under conditions that are representative of processes occurring in response to changing environmental conditions within the disposal facility; the effect of wasteform aging on chemical, physical, and radiological properties; and the associated impact on contaminant release.

This knowledge will enable accurate prediction of radionuclide fate when the wasteforms come in contact with groundwater. Data collected throughout the course of this work will be used to quantify the efficacy of concrete wasteforms, similar to those used in the disposal of low-level waste and mixed low-level waste, for the immobilization of key radionuclides (i.e., uranium, technetium, and iodine). Data collected will also be used to quantify the physical and chemical properties of the concrete affecting radionuclide retention. 



\section{Acknowledgments}

Funding for this project was provided by CH2M HILL Plateau Remediation Company (Sunil Mehta). This work was conducted at Pacific Northwest National Laboratory, operated by Battelle Memorial Institute for the U.S. Department of Energy under Contract DE-AC05-76RL01830. 



\section{Acronyms and Abbreviations}

$\begin{array}{ll}\text { DOE } & \text { U.S. Department of Energy } \\ \text { EDS } & \text { energy dispersive x-ray spectroscopy } \\ \text { ICP-MS } & \text { inductively coupled plasma-mass spectrometry } \\ \text { ICP-OES } & \text { inductively coupled plasma-optical emission spectrometry } \\ \text { LLBG } & \text { Hanford Low-Level Waste Burial Grounds } \\ \text { LLW } & \text { low-level waste } \\ \text { MLLW } & \text { mixed low-level waste } \\ \text { PCT } & \text { product consistency test } \\ \text { PUF } & \text { pressurized unsaturated flow } \\ \text { SEM } & \text { scanning electron microscopy } \\ \text { SV } & \text { surface-area-to-solution volume ratio } \\ \text { XRD } & \text { x-ray diffraction } \\ \text { XRF } & \text { X-ray fluorescence }\end{array}$





\section{Contents}

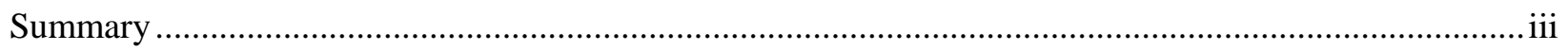

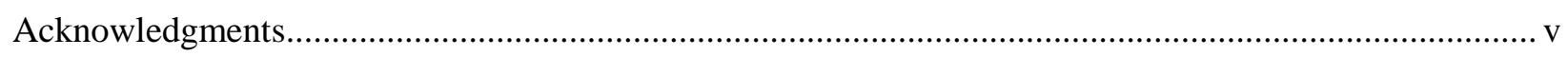

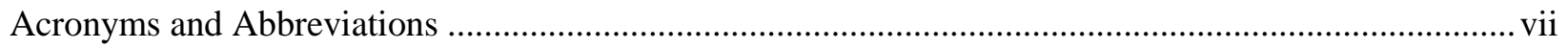

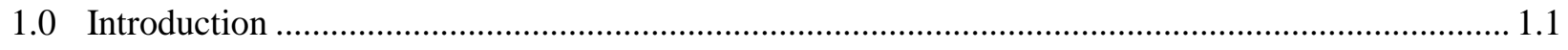

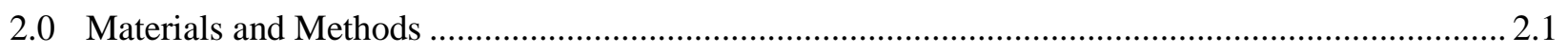

2.1 Specified Concrete Composition for Encasement................................................................ 2.1

2.2 Materials and Laboratory-Scale Mixture Design ................................................................ 2.1

2.3 Concrete Mix and Specimen Preparation ........................................................................... 2.2

2.4 Product Consistency Test Experiments .............................................................................. 2.2

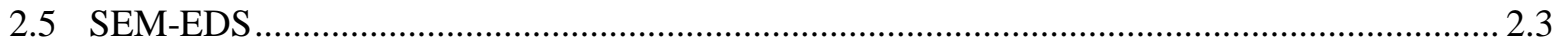

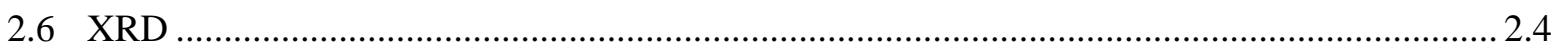

2.7 Pressurized Unsaturated Flow Apparatus Experiments ......................................................... 2.4

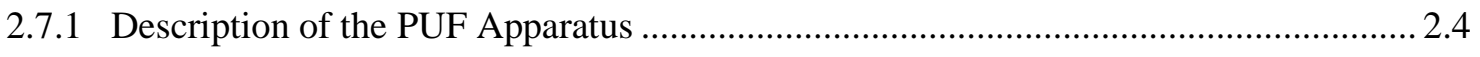

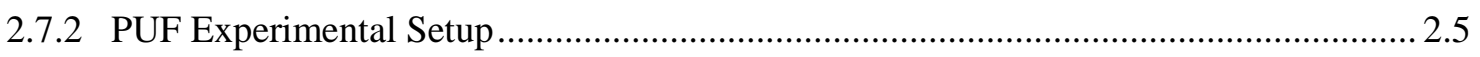

2.7.3 Release Rate and Error Calculations ….......................................................................... 2.6

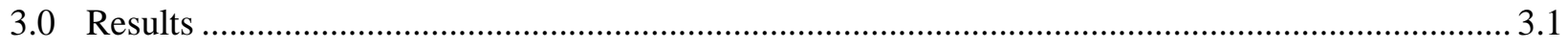

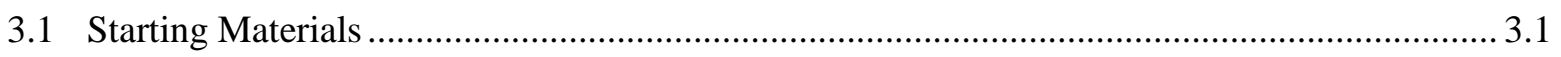

3.2 Results From the Control Granular and Monolith Samples .................................................. 3.2

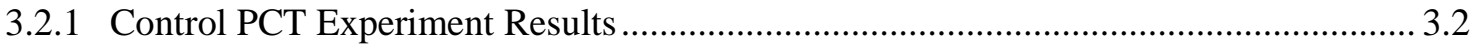

3.3 Results from the Iodine Granular and Monolith Samples .................................................... 3.3

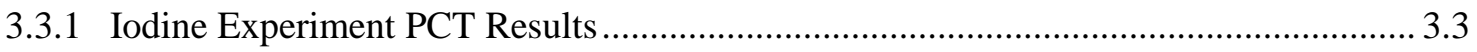

3.4 Results From the Technetium Granular and Monolith Samples .............................................. 3.4

3.4.1 Technetium Experiment PCT Results ..................................................................... 3.4

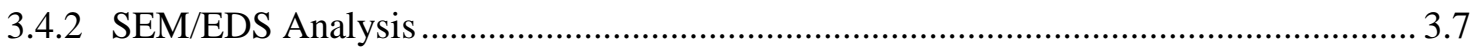

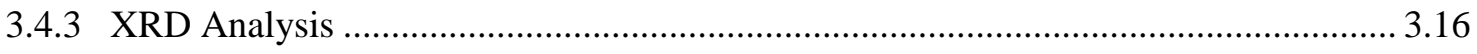

3.5 Technetium-Spiked Sample Results and Discussion ..........................................................19

3.6 Results from the Uranium Granular and Monolith Samples ................................................ 3.20

3.6.1 Uranium PCT Experiment Results ....................................................................... 3.20

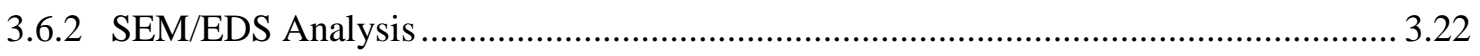

3.7 Uranium-Spiked Sample Results and Discussion ............................................................ 3.40

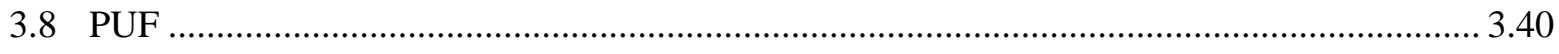

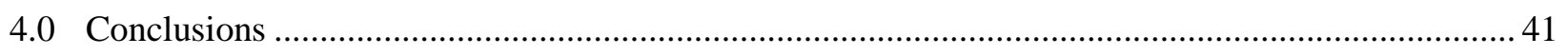

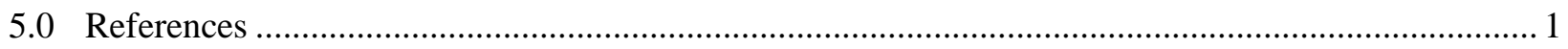




\section{Figures}

Figure 2.1. PUF column assembly

Figure 3.1. PCT results showing the normalized concentrations ( $\mathrm{g} / \mathrm{L}$ ) of calcium over the test duration (in days) for the control monolith and granular samples.

Figure 3.2. PCT results showing the normalized concentrations $(\mathrm{g} / \mathrm{L})$ of iodine over the test duration (in days) for the iodine-spiked monolith and granular samples .....

Figure 3.3. PCT results showing the normalized concentrations ( $\mathrm{g} / \mathrm{L}$ ) of technetium over the test duration (in days) for the technetium-spiked monolith and granular samples.

Figure 3.4. PCT results showing the normalized concentrations (g/L) of calcium over the test duration (in days) for the technetium-spiked monolith and granular samples.

Figure 3.5. PCT results showing the normalized concentrations $(\mathrm{g} / \mathrm{L})$ of sodium over the test duration (in days) for the technetium-spiked monolith and granular samples.

Figure 3.6. SEM and EDS analysis results for the technetium-spiked granular sample, 1:1 solidto-solution ratio conducted at $25^{\circ} \mathrm{C}$

Figure 3.7. SEM and EDS analysis results for the technetium-spiked granular sample, 1:1 solidto-solution ratio conducted at $25^{\circ} \mathrm{C}$

Figure 3.8. SEM and EDS analysis results for the technetium-spiked granular sample, 1:1 solidto-solution ratio conducted at $25^{\circ} \mathrm{C}$.

Figure 3.9. SEM and EDS analysis results for the technetium-spiked granular sample, 1:1 solidto-solution ratio conducted at $25^{\circ} \mathrm{C}$

Figure 3.10. SEM and EDS analysis results for the technetium-spiked granular sample, 1:1 solidto-solution ratio conducted at $25^{\circ} \mathrm{C}$.

Figure 3.11. SEM/EDS analysis results for technetium-spiked granular sample, 1:10 solid-tosolution ratio conducted at $25^{\circ} \mathrm{C}$

Figure 3.12. SEM/EDS analysis results for technetium-spiked granular sample, 1:10 solid-tosolution ratio conducted at $25^{\circ} \mathrm{C}$......

Figure 3.13. SEM/EDS analysis results for technetium-spiked granular sample, 1:10 solid-tosolution ratio conducted at $25^{\circ} \mathrm{C}$.....

Figure 3.14. SEM/EDS analysis results for technetium-spiked granular sample, 1:1 solid-tosolution ratio conducted at $60^{\circ} \mathrm{C}$

Figure 3.15. SEM/EDS analysis results for technetium-spiked granular sample, 1:1 solid-tosolution ratio conducted at $60^{\circ} \mathrm{C}$.....

Figure 3.16. SEM/EDS analysis results for technetium-spiked granular sample, 1:10 solid-tosolution ratio conducted at $60^{\circ} \mathrm{C}$

Figure 3.17. SEM/EDS analysis results for technetium-spiked granular sample, 1:10 solid-tosolution ratio conducted at $60^{\circ} \mathrm{C}$

Figure 3.18. XRD results for technetium-spiked granular sample, 1:1 solid-to-solution ratio conducted at $25^{\circ} \mathrm{C}$.

Figure 3.19. XRD results for technetium-spiked granular sample, 1:10 solid-to-solution ratio conducted at $25^{\circ} \mathrm{C}$.

Figure 3.20. XRD results for technetium-spiked granular sample, 1:1 solid-to-solution ratio conducted at $60^{\circ} \mathrm{C}$. 
Figure 3.21. XRD results for technetium-spiked granular sample, 1:10 solid-to-solution ratio conducted at $60^{\circ}$

Figure 3.22. PCT results showing the normalized concentrations $(\mathrm{g} / \mathrm{L})$ of uranium over the test duration (in days) for the monolith and granular uranium-spiked samples

Figure 3.23. PCT results showing the normalized concentrations (g/L) of calcium over the test duration (in days) for the monolith and granular uranium-spiked samples

Figure 3.24. PCT results showing the normalized concentrations $(\mathrm{g} / \mathrm{L})$ of sodium over the test duration (in days) for the monolith and granular uranium-spiked samples

Figure 3.25. SEM/EDS analysis results for uranium-spiked granular sample, 1:1 solid-to-solution ratio conducted at $25^{\circ} \mathrm{C}$

Figure 3.26. SEM/EDS analysis results for uranium-spiked granular sample, 1:1 solid-to-solution ratio conducted at $25^{\circ} \mathrm{C}$

Figure 3.27. SEM/EDS analysis results for uranium-spiked granular sample, 1:1 solid-to-solution ratio conducted at $25^{\circ} \mathrm{C}$

Figure 3.28. SEM/EDS analysis results for uranium-spiked granular sample, 1:1 solid-to-solution ratio conducted at $25^{\circ} \mathrm{C}$

Figure 3.29. SEM/EDS analysis results for uranium-spiked granular sample, 1:10 solid-tosolution ratio conducted at $25^{\circ} \mathrm{C}$....

Figure 3.30. SEM/EDS analysis results for uranium-spiked granular sample, 1:10 solid-tosolution ratio conducted at $25^{\circ} \mathrm{C}$

Figure 3.31. SEM/EDS analysis results for uranium-spiked granular sample, 1:10 solid-tosolution ratio conducted at $25^{\circ} \mathrm{C}$......

Figure 3.32. SEM/EDS analysis results for uranium-spiked monolith sample, 1:1 solid-tosolution ratio conducted at $25^{\circ} \mathrm{C}$.....

Figure 3.33. SEM/EDS analysis results for uranium-spiked monolith sample, 1:1 solid-tosolution ratio conducted at $25^{\circ} \mathrm{C}$.

Figure 3.34. SEM/EDS analysis results for uranium-spiked monolith sample, 1:1 solid-tosolution ratio conducted at $25^{\circ} \mathrm{C}$.

Figure 3.35. SEM/EDS analysis results for uranium-spiked monolith sample, 1:10 solid-tosolution ratio conducted at $25^{\circ} \mathrm{C}$

Figure 3.36. SEM/EDS analysis results for uranium-spiked monolith sample, 1:10 solid-tosolution ratio conducted at $25^{\circ} \mathrm{C}$......

Figure 3.37. SEM/EDS analysis results for uranium-spiked monolith sample, 1:10 solid-tosolution ratio conducted at $25^{\circ} \mathrm{C}$

Figure 3.38. SEM/EDS analysis results for uranium-spiked granular sample, 1:1 solid-to-solution ratio conducted at $60^{\circ} \mathrm{C}$

Figure 3.39. SEM/EDS analysis results for uranium-spiked granular sample, 1:1 solid-to-solution ratio conducted at $60^{\circ} \mathrm{C}$

Figure 3.40. SEM/EDS analysis results for uranium-spiked granular sample, 1:10 solid-tosolution ratio conducted at $60^{\circ} \mathrm{C}$

Figure 3.41. SEM/EDS analysis results for uranium-spiked granular sample, 1:10 solid-tosolution ratio conducted at $60^{\circ} \mathrm{C}$......

Figure 3.42. SEM/EDS analysis results for uranium-spiked granular sample, 1:10 solid-tosolution ratio conducted at $60^{\circ} \mathrm{C}$, 
Figure 3.43. SEM/EDS analysis results for uranium-spiked granular sample, 1:10 solid-tosolution ratio conducted at $60^{\circ} \mathrm{C}$

Figure 3.44. SEM/EDS analysis results for uranium-spiked monolith sample, 1:1 solid-tosolution ratio conducted at $60^{\circ} \mathrm{C}$

Figure 3.45. SEM/EDS analysis results for uranium-spiked monolith sample, 1:1 solid-tosolution ratio conducted at $60^{\circ} \mathrm{C}$.....

Figure 3.46. SEM/EDS analysis results for uranium-spiked monolith sample, 1:1 solid-tosolution ratio conducted at $60^{\circ} \mathrm{C}$

Figure 3.47. SEM/EDS analysis results for uranium-spiked monolith sample, 1:10 solid-tosolution ratio conducted at $60^{\circ} \mathrm{C}$

Figure 3.48. SEM/EDS analysis results for uranium-spiked monolith sample, 1:10 solid-tosolution ratio conducted at $60^{\circ} \mathrm{C}$.

Figure 3.49. SEM/EDS analysis results for uranium-spiked monolith sample, 1:10 solid-tosolution ratio conducted at $60^{\circ} \mathrm{C}$

Figure 3.50. SEM/EDS analysis results for uranium-spiked monolith sample, 1:10 solid-tosolution ratio conducted at $60^{\circ} \mathrm{C}$

Figure 3.51. SEM/EDS analysis results for uranium-spiked monolith sample, 1:10 solid-tosolution ratio conducted at $60^{\circ} \mathrm{C}$

Figure 3.52. SEM/EDS analysis results for uranium-spiked monolith sample, 1:10 solid-tosolution ratio conducted at $60^{\circ} \mathrm{C}$ 


\section{Tables}

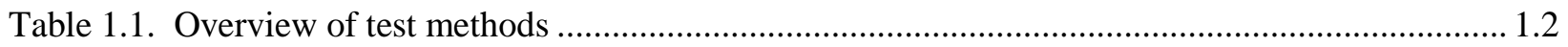

Table 2.1. Concrete material specifications and composition.............................................................. 2.1

Table 2.2. Laboratory-scale material specification and composition....................................................... 2.2

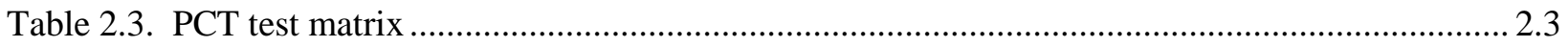

Table 3.1. Normalized major elements in the control, iodine-spiked and uranium-spiked starting concrete material as weight \% obtained from XRF analysis ............................................... 3.1

Table 3.2. ICP-MS results from starting concrete material ................................................................... 3.2 



\subsection{Introduction}

The Waste Management Project provides safe, compliant, and cost-effective waste management services for the Hanford Site and the U.S. Department of Energy (DOE) Complex. Part of these services includes safe disposal of low-level waste (LLW) and mixed low-level waste (MLLW) at the Hanford Low-Level Waste Burial Grounds (LLBG) in accordance with the requirements in DOE Order 435.1, Radioactive Waste Management. To partially satisfy these requirements, performance assessment analyses were completed and approved. DOE Order 435.1 also requires that continuing data collection be conducted to enhance confidence in the critical assumptions used in these analyses to characterize the operational features of the disposal facility that are relied upon to satisfy the performance objectives identified in the Order.

One critical assumption is that concrete will frequently be used as a waste form or container material to control and minimize the release of radionuclide constituents in waste into the surrounding environment. Concrete encasement would contain and isolate the waste packages from the hydrologic environment and act as an intrusion barrier. Any failure of concrete encasement may result in water intrusion and consequent mobilization of radionuclides from the waste packages. The radionuclides iodine-129 $\left({ }^{129} \mathrm{I}\right)$, selenium-75 $\left({ }^{75} \mathrm{Se}\right)$, technetium-99 $\left({ }^{99} \mathrm{Tc}\right)$, and uranium-238 $\left({ }^{238} \mathrm{U}\right)$ have been identified as long-term dose contributors (Mann et al. 2001; Wood et al. 2001), which, because of their anionic nature in aqueous solutions, may escape from the encased concrete by mass flow and/or diffusion and migrate into the surrounding subsurface environment (Serne et al. 1989; 1992a, b; 1993; 1995). Therefore, it is necessary to assess the performance of the concrete encasement structure and the ability of the surrounding soil to retard radionuclide migration. A critical component of this is to provide 1) quantitative estimates of radionuclide retention within concrete wasteform materials (source term) similar to those used to encapsulate waste in the LLBG, and 2) measures of the effect of concrete wasteform properties on radionuclide release and migration within the near-field environment.

Computer models are essential for this purpose because impacts on groundwater resources must be projected out to periods of 10,000 years and longer. Predictive codes require input of two main general classifications of data: 1) multiphase flow, and 2) reactive transport. Multiphase flow input is defined in the near-field hydraulic properties data package or the far-field hydraulic properties data package (Meyer and Serne 1999).

Laboratory testing provides a majority of the key input data required to assess the long-term performance of source-terms and near-field radionuclide transport and fate. Details on the recommended technical strategy for developing this understanding have been published (McGrail et al. 1998) and reviewed by an international panel of experts. The objective of this investigation was to implement this strategy to experimentally quantify the necessary input data for predictive simulations of radionuclide release, transport, and fate from concrete source-terms in the near field environment.

The experimental materials, methods, and initial data from two principal methods, as described by McGrail et al. (1998), are discussed in this data package, including the pressurized unsaturated flow (PUF) test and product consistency test (PCT). Each of these test methods focuses on different aspects of the concrete wasteform weathering process. Linkages between the test methods, their principal function, and the data they provide for predictive modeling are described in Table 1.1 (McGrail et al. 1998). 
Table 1.1. Overview of test methods

\begin{tabular}{lclll}
\hline $\begin{array}{c}\text { Test } \\
\text { Method }\end{array}$ & $\begin{array}{c}\text { Temperature } \\
\text { Range }\end{array}$ & Duration & \multicolumn{1}{c}{ Purpose } & \multicolumn{1}{c}{ Data Provided } \\
\hline PCT & 20 to $100^{\circ} \mathrm{C}$ & $\begin{array}{l}\text { Weeks to } \\
\text { years }\end{array}$ & $\begin{array}{l}\text { Quantitative estimates of } \\
\text { radionuclide retention within } \\
\text { concrete wasteform materials } \\
\text { (source term) }\end{array}$ & $\begin{array}{l}\text { Solution composition and dissolution } \\
\text { rate as a function of surface area to } \\
\text { solution volume ratio and } \\
\text { temperature, secondary phases }\end{array}$ \\
PUF & 40 to $100^{\circ} \mathrm{C}$ & $\begin{array}{l}\text { Months to } \\
\text { years }\end{array}$ & $\begin{array}{l}\text { Measures the effect of concrete } \\
\text { wasteform properties on } \\
\text { radionuc1ide release and } \\
\text { migration within the near-field } \\
\text { environment }\end{array}$ & $\begin{array}{l}\text { Effluent chemical composition and } \\
\text { dissolution rate as a function of } \\
\text { temperature and flow rate, secondary } \\
\text { phases, hydraulic property changes }\end{array}$ \\
\hline
\end{tabular}




\subsection{Materials and Methods}

\subsection{Specified Concrete Composition for Encasement}

The concrete composition for the burial encasement was specified in Specification for Concrete Encasement for Contact-Handled Category 3 Waste. ${ }^{1}$ This specification was used as the basis to prepare a concrete for fabrication of test specimens. The composition includes sulfate-resistant Portland Type I or Type II cement, a pozzolanic material (Class F fly ash), fine and coarse aggregates, and steel fiber. Additional specifications include a water-to-cement ratio of 0.4 and an air content $6.0 \pm 1.5 \%$. The nominal proportions and material specifications based on this initial design are listed in Table 2.1.

Table 2.1. Concrete material specifications and composition

\begin{tabular}{llcc}
\hline \multicolumn{1}{c}{ Material } & \multicolumn{1}{c}{ Specifications } & $\begin{array}{c}\text { Specified Field } \\
\text { Mix }\end{array}$ & $\begin{array}{c}\text { Sormalized } \\
\text { Specification } \\
\text { Design }\end{array}$ \\
\hline Cement & Portland Type I or Type I/II sulfate-resistant cement & $381 \mathrm{~kg} / \mathrm{m}^{3}$ & 0.27 \\
Fly Ash & Class F fly ash; nominal 15\% of cement by volume & $54 \mathrm{~kg} / \mathrm{m}^{3}$ & 0.04 \\
Coarse Aggregate & No. 676 or equivalent (3/4" nominal size) & $55 \%$ by volume & 0.04 \\
Fine Aggregate & Sand & $45 \%$ by volume & 0.51 \\
Water & Nominal water-to-cement ratio: 0.4 & $399 \mathrm{~kg} / \mathrm{m}^{3}$ & 0.10 \\
Steel Fiber & Deformed Type I, nominal length $2.5-3.8 \mathrm{~cm}\left(1-1.5^{\prime \prime}\right)$ & $59 \mathrm{~kg} / \mathrm{m}^{3}$ & 0.04 \\
Air Content & & $6.0 \pm 1.5 \%$ & \\
\hline
\end{tabular}

\subsection{Materials and Laboratory-Scale Mixture Design}

A laboratory-scale concrete mixture (Table 2.2) was prepared based on specifications shown in Table 2.1. Because of the required small dimensions of laboratory test specimens, the coarse aggregate was omitted, the sand used was 40-60 mesh $(0.420-0.250 \mathrm{~mm})$ Accusand and the steel fiber used was a smaller diameter iron powder 80-100 mesh $(0.149-0.177 \mathrm{~mm})$. Based on these modifications, a concrete mix was prepared that consisted of Portland Cement (Type III, ASTM C-150 compliant), Class F fly ash, sand, iron powder, and a water-entraining agent (PolyHeed 997). The water-entraining agent was included in the mix to facilitate the workability of the concrete. The volumes of the PolyHeed 997 and the air-entraining agent, MB-AE 90, were not included in the normalization calculations because of their negligible contribution to the overall mix volume. The material specification and composition for the laboratory-scale concrete mixture is given in Table 2.2.

Additionally, the water component used to prepare the respective concrete monoliths was spiked with the experimental radionuclide of interest. Technetium-bearing concrete specimens were prepared using water spiked with sodium pertechnetate to provide an equivalent concentration of $300 \mathrm{mg} / \mathrm{kg}$ technetium. Uranyl nitrate and sodium iodide were used to prepare monoliths containing $20 \mathrm{mg} / \mathrm{kg}$ uranium and $300 \mathrm{mg} / \mathrm{kg}$ iodine, respectively. The concentrations used were below saturation limits for homogeneous

\footnotetext{
1 “Specification for Concrete Encasement for Contact-Handled Category 3 Waste.” 1998. Proceedings of Waste Management.
} 
precipitation, but sufficient to allow for measurable release, transport, and fate measurements within the PUF column tests.

Table 2.2. Laboratory-scale material specification and composition

\begin{tabular}{|c|c|c|c|}
\hline Material & $\begin{array}{l}\text { Material Specifications } \\
\text { for Field Mix }\end{array}$ & $\begin{array}{l}\text { Normalized } \\
\text { Laboratory } \\
\text { Design }\end{array}$ & $\begin{array}{l}\text { Material Specifications Used in } \\
\text { Revised Laboratory Mix Comparison }\end{array}$ \\
\hline Cement & $\begin{array}{l}\text { Portland Type I or Type I/II } \\
\text { sulfate-resistant cement }\end{array}$ & 0.27 & Portland Type III \\
\hline Fly Ash & $\begin{array}{l}\text { Class F fly ash; nominal 15\% of } \\
\text { cement by volume }\end{array}$ & 0.04 & $\begin{array}{l}\text { Class F fly ash; nominal } 20 \% \text { of } \\
\text { cement by volume }\end{array}$ \\
\hline Fine Aggregate & Sand & 0.51 & $\begin{array}{l}\text { Industrial quartz Accusand } 40-60 \\
\text { mesh }(0.420-0.250 \mathrm{~mm})\end{array}$ \\
\hline Water & Nominal water-to-cement ratio: 0.4 & 0.10 & Water-to-cement ratio: 0.5 \\
\hline Steel Fiber & $\begin{array}{l}\text { Deformed Type I, nominal length } \\
2.5-3.8 \mathrm{~cm}\left(1-1.5^{\prime \prime}\right)\end{array}$ & 0.04 & $\begin{array}{l}\text { Iron powder } 80-100 \text { mesh }(0.149- \\
0.177 \mathrm{~mm}) \text {. }\end{array}$ \\
\hline PolyHeed 997 & -- & 0.00375 & Water-entraining agent \\
\hline Air Content & $6.0 \pm 1.5 \%$ & $6.0 \pm 1.5 \%$ & -- \\
\hline
\end{tabular}

\subsection{Concrete Mix and Specimen Preparation}

Concrete monoliths were prepared with mix components added in this order: water, iron powder (if applicable), sand, fly ash, cement, PolyHeed 997, and MB-AE 90. The concrete was mixed in a plastic beaker and poured into 7-mL scintillation vials in the vertical positions. After filling half way, the molds were vibrated using a vortexer until a significant decrease in the release of air bubbles was observed, then the sample molds were filled. After the molds were filled, a rod was used to eliminate the interface between the two layers. The forms were stored in a humidity chamber for 7 days, the molds were removed, and the monoliths were returned to the humidity chamber for 21 additional days to provide moisture while the concrete set.

\subsection{Product Consistency Test Experiments}

The product consistency test has been standardized as an ASTM standard procedure (ASTM 1994). The ASTM standard includes two methods: PCT Method A was developed specifically for verifying process control during production of vitrified high-level waste (HLW) forms and is conducted with specific values of test parameters; PCT Method B does not specify the values of test parameters. Because the PCT Method B encompasses commonly used variations of test parameters, PCT Method B was used in this work involving concrete wasteform.

The PCTs were conducted by placing a fixed amount of concrete wasteform monolith or crushed sample with de-ionized water in a Teflon reaction vessel at $25^{\circ} \mathrm{C}$ or $60^{\circ} \mathrm{C}$. Two concrete wasteform surface-area-to-solution volume ratios (S/V) were used: 1) $1 \mathrm{~g}$ of concrete wasteform per $10 \mathrm{~mL}$ of deionized water to give an S/V of $2000 \mathrm{~m}^{-1}$, and 2) $1 \mathrm{~g}$ of concrete wasteform per $1 \mathrm{~mL}$ of de-ionized water to give an $\mathrm{S} / \mathrm{V}$ of $20,000 \mathrm{~m}^{-1}$. The tests were conducted with concrete monoliths and crushed concrete wasteform samples. To limit water loss for long-duration experiments, the Teflon perfluoroalkoxy polymer resin (PFA) reactors were sealed inside a stainless steel Parr reactor. At the end of the test, the solutions were analyzed for the concentrations of dissolved concrete components by inductively coupled 
plasma-optical emission spectrometry (ICP-OES) and inductively coupled plasma-mass spectrometry (ICP-MS). Scanning electron microscopy-energy dispersive spectrometry (SEM-EDS) and x-ray diffraction (XRD) were used to analyze the solid phases and evaluate alterations in the mineralogical composition.

Table 2.3. PCT test matrix

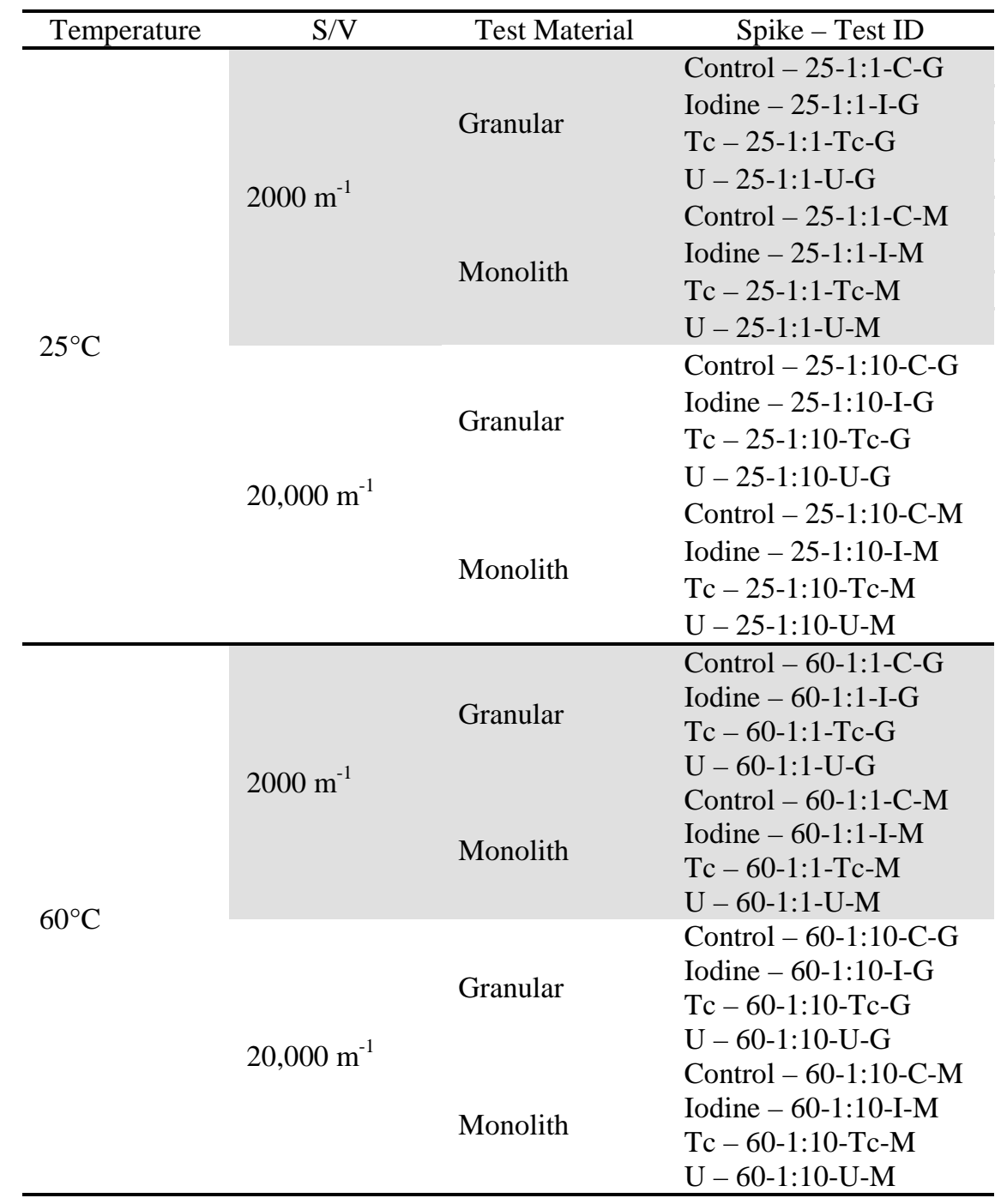

\subsection{SEM-EDS}

A JEOL 5910-LV instrument with an EDAX Sapphire ultra thin window (UDW) detector was used for SEM images and energy dispersive x-ray spectroscopy EDS analysis. For the majority of the samples, the accelerating voltage was set at $20 \mathrm{kV}$ (with a couple exceptions at $15 \mathrm{kV}$ ). Images were produced in both secondary electron and backscatter modes with objective lens aperture 2 at $30 \mu \mathrm{m}$ diameter and spot sizes ranging from 30 to $40 \mu \mathrm{m}$.

For the ground samples, a small specimen was mounted onto an SEM stud using double-sided carbon tape. All of these samples were coated with gold for 2 to 4 minutes at a rate of $320 \AA$ per minute. Due to 
interference in the area near the Tc peak, the Tc-containing samples were repeated without gold coating. The lack of coating on these non-conductive samples restricted the analysis to low vacuum and backscatter imaging. For the monolith samples, the entire monolith was mounted to an SEM stud with the double-sided carbon tape. These samples were needed intact for further analysis; therefore, gold coating was not an option to increase conductivity. This again restricted analysis to low vacuum and backscatter imaging.

\subsection{XRD}

Powder XRD patterns were collected on the solid materials using a Rigaku Ultima IV x-ray diffractometer equipped with a copper source and a D/Tex detector. The samples were acquired at $40 \mathrm{kV}$, $44 \mathrm{~mA}$ from 5 to $65^{\circ}$ with a 0.02 step size and 10 degree per minute dwell time.

\subsection{Pressurized Unsaturated Flow Apparatus Experiments}

The pressurized unsaturated flow apparatus allows for accelerated weathering experiments to be conducted under hydraulically unsaturated conditions, thereby mimicking the vadose zone environment while allowing the weathering wasteform to achieve a final reaction state. The PUF apparatus provides the capability to vary the volumetric water content from saturation to $20 \%$ of saturation or less, minimize the flow rate to increase liquid residence time, and operate at a maximum temperature of $100^{\circ} \mathrm{C}$. The PUF column operates under a hydraulically unsaturated condition by creating a steady state vertical water flow, while maintaining uniform water content throughout the column, and by using gravity to assist in drainage.

The underlying principle for creating such conditions is Darcy's Law as modified by Richards (1931):

$$
J_{w}=-K\left(\psi_{m}\right) \frac{\delta \psi}{\delta z}
$$

where $\quad J_{w} \quad=$ volumetric flux density; $\mathrm{m} \mathrm{s}^{-1}$

$\psi \quad=$ water potential (equal to the matric potential $\left[\psi_{m}\right]+$ gravitational potential $\left[\psi_{g}\right]$ ), $\mathrm{m}$

$K\left(\psi_{m}\right)=$ hydraulic conductivity as a function of matrix potential, $\mathrm{m} \mathrm{s}^{-1}$

$\mathrm{Z} \quad$ = length of the column, $\mathrm{m}$

It can be easily shown that if uniform moisture content is established throughout the column equation reduces to

$$
J_{w}=K\left(\psi_{m}\right)
$$

Equation (2) simply states that under uniform water content conditions, the volumetric flux density of water is equal to the unsaturated hydraulic conductivity.

\subsubsection{Description of the PUF Apparatus}

The PUF system has been previously described in other publications (Wierenga and Van Genuchten 1989; McGrail et al. 1997, 1999; Pierce et al. 2006). Only a general description is provided in this 
document. In general, the PUF system consist of a column (7.62-cm length and 1.91-cm diameter) fabricated from a chemically inert material, polyetheretherketone (PEEK), so that weathering reactions are not influenced by interaction with the column material (Figure 2.1). A porous titanium (Ti) plate with nominal pore size of $0.2 \mu \mathrm{m}$ is sealed in the bottom of the column to ensure an adequate pressure differential for the conductance of fluid while operating under unsaturated conditions (Wierenga 1993). Titanium was chosen because it is highly resistant to corrosion and has excellent wetting properties. Once the porous Ti-plate is water saturated, water but not air is allowed to flow through the $0.2-\mu \mathrm{m}$ pores, as long as the applied pressure differential does not exceed the air entry relief pressure or "bubble pressure" of the Ti-plate. If the pressure differential is exceeded, air will escape through the plate and compromise the ability to maintain unsaturated flow conditions in the column. The computer control system runs LabVIEW (National Instruments Corporation) software for logging test data to disk from several thermocouples, pressure sensors, in-line sensors for effluent $\mathrm{pH}$ and conductivity, and column weight from an electronic strain gauge to accurately track water mass balance and saturation level. The column also includes a "PUF port," which is an electronically actuated valve that periodically vents the column gases. The purpose of column venting is to prevent reduction in the partial pressure of important gases, especially $\mathrm{O}_{2}$ and $\mathrm{CO}_{2}$, which may be consumed in a variety of chemical reactions.

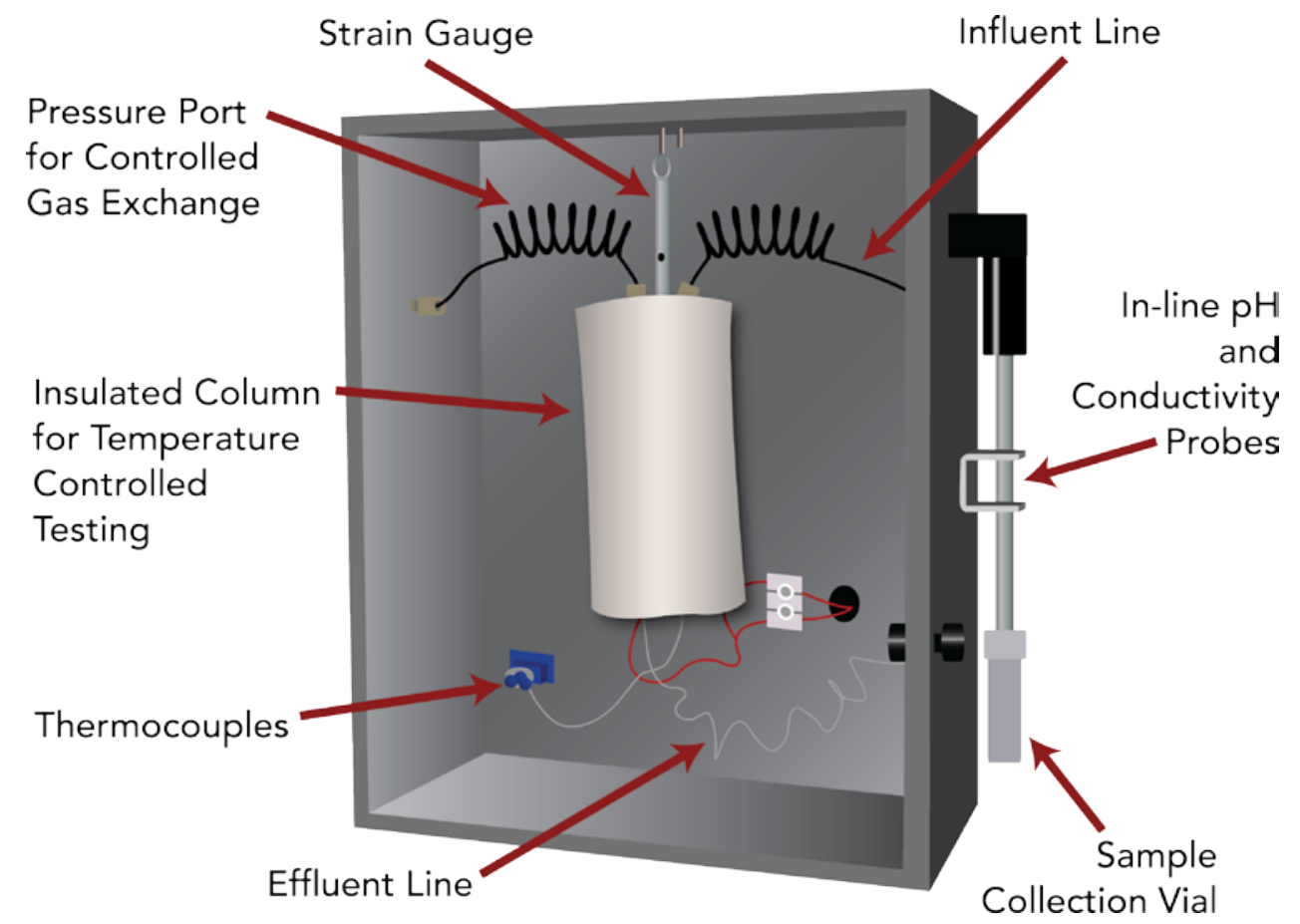

Figure 2.1. PUF column assembly

\subsubsection{PUF Experimental Setup}

A total of four PUF tests were conducted: 1) control column consisting of five pieces of a concrete monolith with a total combined surface area of $2.55 \times 10^{3} \mathrm{~mm}^{2}$, 2) iodine-spiked concrete monolith with a surface area of $2.50 \times 10^{3} \mathrm{~mm}^{2}$, 3) uranium-spiked monolith with a surface area of $2.61 \times 10^{3} \mathrm{~mm}^{2}$, and 4) technetium-spiked monolith with a surface area of $2.42 \times 10^{3} \mathrm{~mm}^{2}$. The total surface area of the concrete specimens was equivalent within experimental error between the PUF tests. However, the control column consisted of five separate concrete monolith samples to afford the total surface area, whereas the others used a single concrete monolith. 
Columns were packed with Hanford medium course sand and radionuclide-bearing concrete monoliths in approximately 5-g increments that were tamped, and the surface was scored prior to adding subsequent layers. The columns were saturated with Hanford groundwater from the bottom up, using vacuum pressure and a flow rate of $10 \mathrm{~mL} / \mathrm{hr}$. The columns were allowed to initially desaturate by gravity drainage and also vented periodically to maintain an internal pressure less than the bubble pressure of the porous plate. The process of fully saturating the column and reducing the water content to the desired level minimizes preferential flow paths; hysteresis verifies the most consistent, uniform attainment of water content within a series of unsaturated columns, and affords a consistent method for establishing unsaturated conditions. Sediment bulk density, $\rho_{b}\left(\mathrm{~g} \mathrm{~cm}^{-3}\right)$, and volumetric water content, $\theta$ $\left(\mathrm{cm} \mathrm{cm}^{-3}\right.$ ), were determined from the mass of the sediment and water. The percent saturation was calculated from the ratio of the volumetric water content to the total porosity, $\phi$, which was calculated from the bulk density and particle density, $\rho_{p}\left(\mathrm{~g} \mathrm{~cm}^{3}\right)$.

Experiments were begun under conditions that allow attainment of moisture contents of $\sim 7$ and 15 $\mathrm{wt} \%$ and are being conducted at temperatures of $23^{\circ} \mathrm{C}$. Flow was initiated with Hanford groundwater at a rate of $2 \mathrm{~mL} /$ day under a pressure of 2 psi. Column venting was set to occur once an hour, so that the partial pressure of $\mathrm{O}_{2}$ and $\mathrm{CO}_{2}$ could remain relatively constant.

All effluent solutions were monitored for $\mathrm{pH}$ with in-line sensors. Prior to starting the experiments, the in-line $\mathrm{pH}$ probe was calibrated with National Bureau of Standards $\mathrm{pH}$ buffers $(\mathrm{pH} 7.00,10.00$, or 12.00 at $25^{\circ} \mathrm{C}$ ). Precision of $\mathrm{pH}$ measurement was $\pm 0.02 \mathrm{pH}$ units. Effluent samples are being collected in tared sample vessels, which are acidified for elemental analysis by ICP-OES and ICP-MS. The columns are being periodically analyzed using non-destructively using X-ray microtomography to evaluate, in situ, changes in porosity due to the formation of alteration phases on and from the weathering of the concrete monoliths.

\subsubsection{Release Rate and Error Calculations}

The results from chemical analyses on collected effluent samples are used to calculate a normalized release rate according to McGrail et al. (2000):

$$
r_{i}=\frac{4 \varepsilon Q\left(c_{i \mathrm{~L}}-c_{i \mathrm{~b}}\right)}{\theta s(1-\varepsilon) \rho \pi \mathrm{d}^{2} \mathrm{~L} f_{i}}
$$

$$
\text { where } \quad \begin{aligned}
r_{i} & =\text { normalized rate of release for ith element, } \mathrm{g} \mathrm{m}^{-2} \mathrm{~d}^{-1} \\
c_{i \mathrm{~L}} & =\text { effluent concentration of ith element, } \mathrm{g} \mathrm{m}^{-3} \\
c_{i \mathrm{~b}} & =\text { background concentration of } i \text { th element, } \mathrm{g} \mathrm{m}^{-3} \\
\mathrm{~d} & =\text { column diameter, } \mathrm{m} \\
f_{i} & =\text { mass fraction of } i^{\text {th }} \text { element in the concrete, unitless } \\
\mathrm{L} & =\text { column length, } \mathrm{m} \\
Q & =\text { volumetric flow rate, } \mathrm{m}^{3} \mathrm{~d}^{-1} \\
s & =\text { specific surface area of the concrete sample, } \mathrm{m}^{2} \mathrm{~g}^{-1} \\
\varepsilon & =\text { porosity, unitless } \\
\rho & =\text { bulk concrete density, } \mathrm{g} \mathrm{m}^{-3} \\
\theta & =\text { volumetric water content, unitless. }
\end{aligned}
$$


An estimate in the uncertainty associated with the normalized rate will be calculated using standard error propagation theory, assuming the variables in Equation (3) are uncorrelated. In this case, the standard deviation of a function $f\left(x_{1}, x_{2}, \ldots x_{\mathrm{n}}\right)$ is given by Equation (4):

$$
\sigma_{f}=\sqrt{\sum_{i=1}^{n}\left(\frac{\partial f}{\partial x}\right)^{2} \sigma_{i}^{2}}
$$

where $\quad \sigma_{f}=$ standard deviation of the function $f$

$$
\begin{aligned}
x_{i} & =\text { parameter } i \\
\sigma_{i} & =\text { standard deviation of parameter } i .
\end{aligned}
$$

Assuming that the error associated with the background concentration $\left(C_{i, b}\right)$, diameter $(d)$, and column length $(L)$ are negligible compared with the other variables, the relative standard deviation is given by

$$
\sigma_{r_{i}}=r_{i} \sqrt{\left(\frac{\tilde{\sigma}_{\varepsilon}}{1-\varepsilon}\right)^{2}+\left(\frac{\tilde{\sigma}_{c_{i, L}}}{1-c_{i, B} / c_{i, L}}\right)^{2}+\tilde{\sigma}_{Q}^{2}+\tilde{\sigma}_{\theta}^{2}+\tilde{\sigma}_{S}^{2}+\tilde{\sigma}_{\rho}^{2}+\tilde{\sigma}_{f_{i}}^{2}}
$$

where the tilde over the $\sigma$ symbol signifies the relative standard deviation for the subscripted parameter. In calculating the error bounds with Equation (5) typical fixed relative standard deviations have been estimated based upon repeatability of laboratory measurements:

$$
\begin{aligned}
& \tilde{\sigma}_{\varepsilon}=6 \%, \tilde{\sigma}_{s}=20 \%, \tilde{\sigma}_{Q}=2 \% \\
& \tilde{\sigma}_{\rho}=5 \%, \tilde{\sigma}_{c_{\mathrm{LL}}}=10 \%, \tilde{\sigma}_{f_{\mathrm{LL}}}=10 \%
\end{aligned}
$$

The value of $\tilde{\sigma}_{\theta}$ is calculated from the variation in water content recorded by the data acquisition system over the discrete interval between each fluid sampling. A computer macro program is available to perform this calculation directly in the Excel spreadsheet used to store the sensor data. 



\subsection{Results}

The long-term stability of materials is controlled by solubility and the rate of dissolution. Under highly advective conditions where the rate of transport is greater than the solubility rate, the stability of the material is controlled by dissolution kinetics. Alternatively, in low to moderately advective environments where the solubility is greater than the rate of mass transport, the long-term stability of the material is based on the solubility of the phase. Complex wasteforms, such as concrete exposed to environmental conditions, may exhibit complex, integrated weathering processes that include dissolution and precipitation of the wasteform itself and the secondary phases that form during reaction. Therefore, to accurately predict the long-term stability of concrete wasteforms under relevant environmental conditions, the rate of wasteform weathering and formation of secondary phases and the identity of relevant secondary phases and their impact on contaminant retention must be known.

\subsection{Starting Materials}

Samples of the starting concrete material used in the control, iodine-spiked, and uranium-spiked experiments were sent to Washington State University for x-ray fluorescence (XRF) and ICP-MS analysis. Table 3.1 shows the weight percent of the major elements. The ICP-MS results from the three starting materials are shown in Table 3.2.

Table 3.1. Normalized major elements in the control, iodine-spiked and uranium-spiked starting concrete material as weight \% obtained from XRF analysis

\begin{tabular}{lccc}
\hline & Control & I-spiked & U-spiked \\
\hline $\mathrm{SiO}_{2}$ & 67.33 & 59.67 & 61.80 \\
$\mathrm{TiO}_{2}$ & 0.232 & 0.238 & 0.228 \\
$\mathrm{Al}_{2} \mathrm{O}_{3}$ & 2.34 & 2.36 & 2.26 \\
$\mathrm{FeO}$ & 8.43 & 15.17 & 15.10 \\
$\mathrm{MnO}$ & 0.056 & 0.107 & 0.103 \\
$\mathrm{MgO}$ & 0.68 & 0.69 & 0.63 \\
$\mathrm{CaO}$ & 20.36 & 21.12 & 19.25 \\
$\mathrm{Na}$ & 0.29 & 0.31 & 0.30 \\
$\mathrm{~K}_{2} \mathrm{O}$ & 0.18 & 0.21 & 0.21 \\
$\mathrm{P}_{2} \mathrm{O}_{5}$ & 0.102 & 0.114 & 0.120 \\
$\mathrm{Total}$ & 100.00 & 100.00 & 100.00 \\
\hline
\end{tabular}


Table 3.2. ICP-MS results from starting concrete material

\begin{tabular}{|c|c|c|c|}
\hline Element & $\begin{array}{l}\text { Control } \\
\text { (ppm) }\end{array}$ & $\begin{array}{l}\text { I-spiked } \\
\text { (ppm) }\end{array}$ & $\begin{array}{l}\text { U-spiked } \\
\text { (ppm) }\end{array}$ \\
\hline $\mathrm{Ba}$ & 142 & 143 & 139 \\
\hline $\mathrm{Ce}$ & 22.37 & 22.80 & 21.87 \\
\hline Cs & 0.14 & 0.16 & 0.14 \\
\hline Dy & 1.45 & 1.49 & 1.47 \\
\hline Er & 0.81 & 0.81 & 0.80 \\
\hline $\mathrm{Eu}$ & 0.38 & 0.38 & 0.37 \\
\hline Gd & 1.57 & 1.57 & 1.52 \\
\hline $\mathrm{Hf}$ & 1.58 & 1.60 & 1.52 \\
\hline Ho & 0.30 & 0.30 & 0.29 \\
\hline $\mathrm{La}$ & 11.02 & 11.10 & 10.69 \\
\hline $\mathrm{Lu}$ & 0.12 & 0.11 & 0.11 \\
\hline $\mathrm{Nb}$ & 7.29 & 7.65 & 7.55 \\
\hline $\mathrm{Nd}$ & 9.63 & 9.67 & 9.46 \\
\hline $\mathrm{Pb}$ & 2.16 & 1.89 & 1.93 \\
\hline $\operatorname{Pr}$ & 2.61 & 2.61 & 2.54 \\
\hline $\mathrm{Rb}$ & 2.7 & 3.1 & 3.1 \\
\hline Sc & 2.7 & 2.7 & 2.7 \\
\hline $\mathrm{Sm}$ & 1.83 & 1.84 & 1.78 \\
\hline $\mathrm{Sr}$ & 323 & 327 & 312 \\
\hline Та & 0.38 & 0.44 & 0.44 \\
\hline $\mathrm{Tb}$ & 0.25 & 0.25 & 0.24 \\
\hline Th & 2.32 & 2.44 & 2.18 \\
\hline $\mathrm{Tm}$ & 0.12 & 0.12 & 0.12 \\
\hline $\mathrm{U}$ & 0.86 & 0.85 & 40.35 \\
\hline $\mathrm{Y}$ & 8.08 & 8.09 & 8.01 \\
\hline $\mathrm{Yb}$ & 0.75 & 0.75 & 0.71 \\
\hline $\mathrm{Zr}$ & 66 & 67 & 64 \\
\hline
\end{tabular}

\subsection{Results From the Control Granular and Monolith Samples}

\subsubsection{Control PCT Experiment Results}

Figure 3.1 summarizes the PCT data for the control granular and monolith samples at different temperatures and surface-area-to-solution volume ratios. The results show that the release of calcium was highest for the $1: 1$ granular control sample at $60^{\circ} \mathrm{C}$. In general, the granular samples displayed the highest release rates except the sample at $1: 1$ and $25^{\circ} \mathrm{C}$, which resulted in some of the lowest normalized concentrations for the test duration. The higher concentrations released by the granular samples is likely due to the higher surface area in the granular samples. 


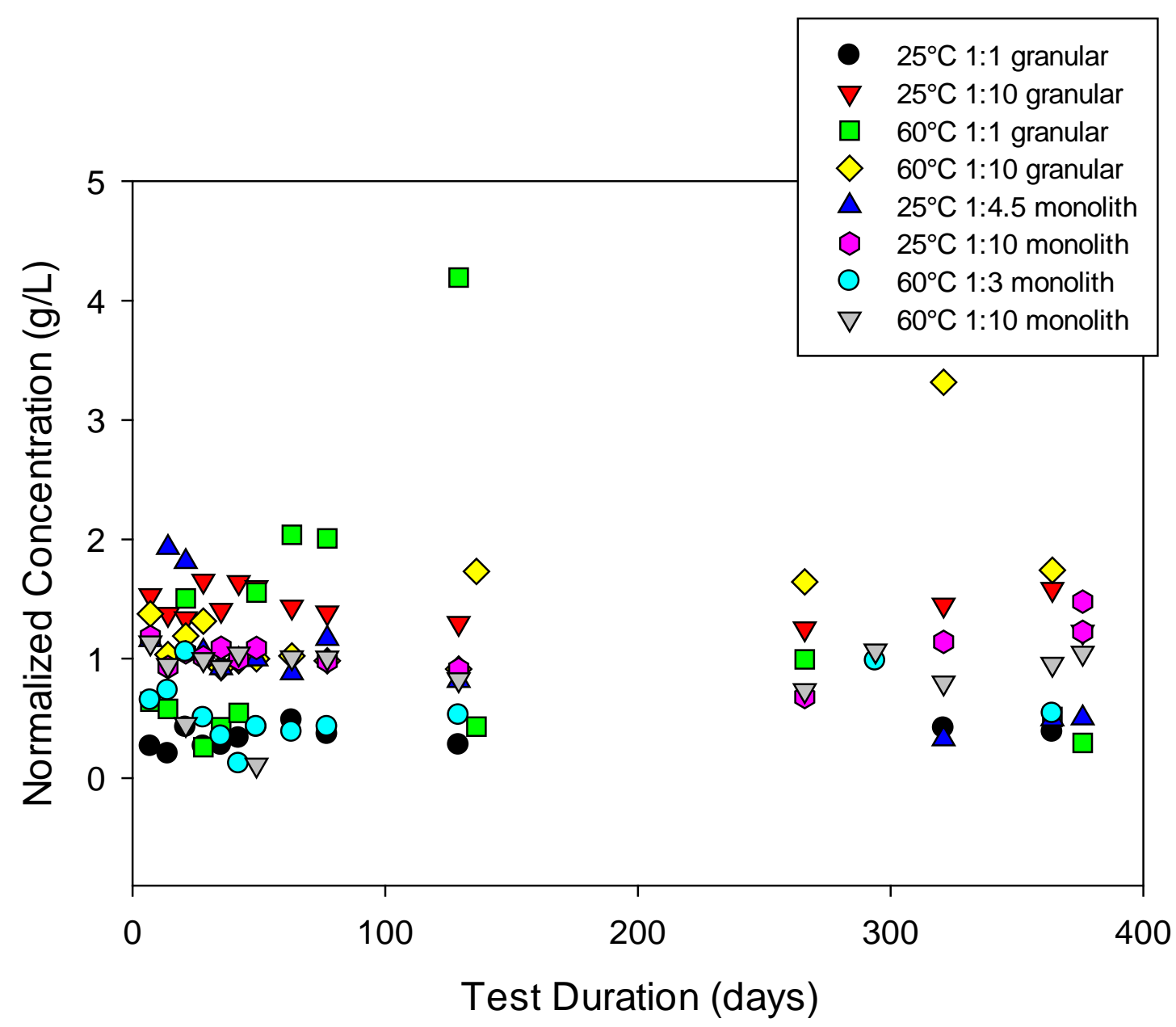

Figure 3.1. PCT results showing the normalized concentrations $(\mathrm{g} / \mathrm{L})$ of calcium over the test duration (in days) for the control monolith and granular samples

\subsection{Results from the lodine Granular and Monolith Samples}

\subsection{1 lodine Experiment PCT Results}

Figure 3.2 summarizes the PCT data for the iodine-spiked granular and monolith samples at different temperatures and surface-area-to-solution volume ratios. The iodine release was highest for the granular 1:1 solid-to-solution ratio at both temperatures. The lowest concentrations of normalized iodine were from the monolith samples at the 1:10 ratio from both temperatures. 


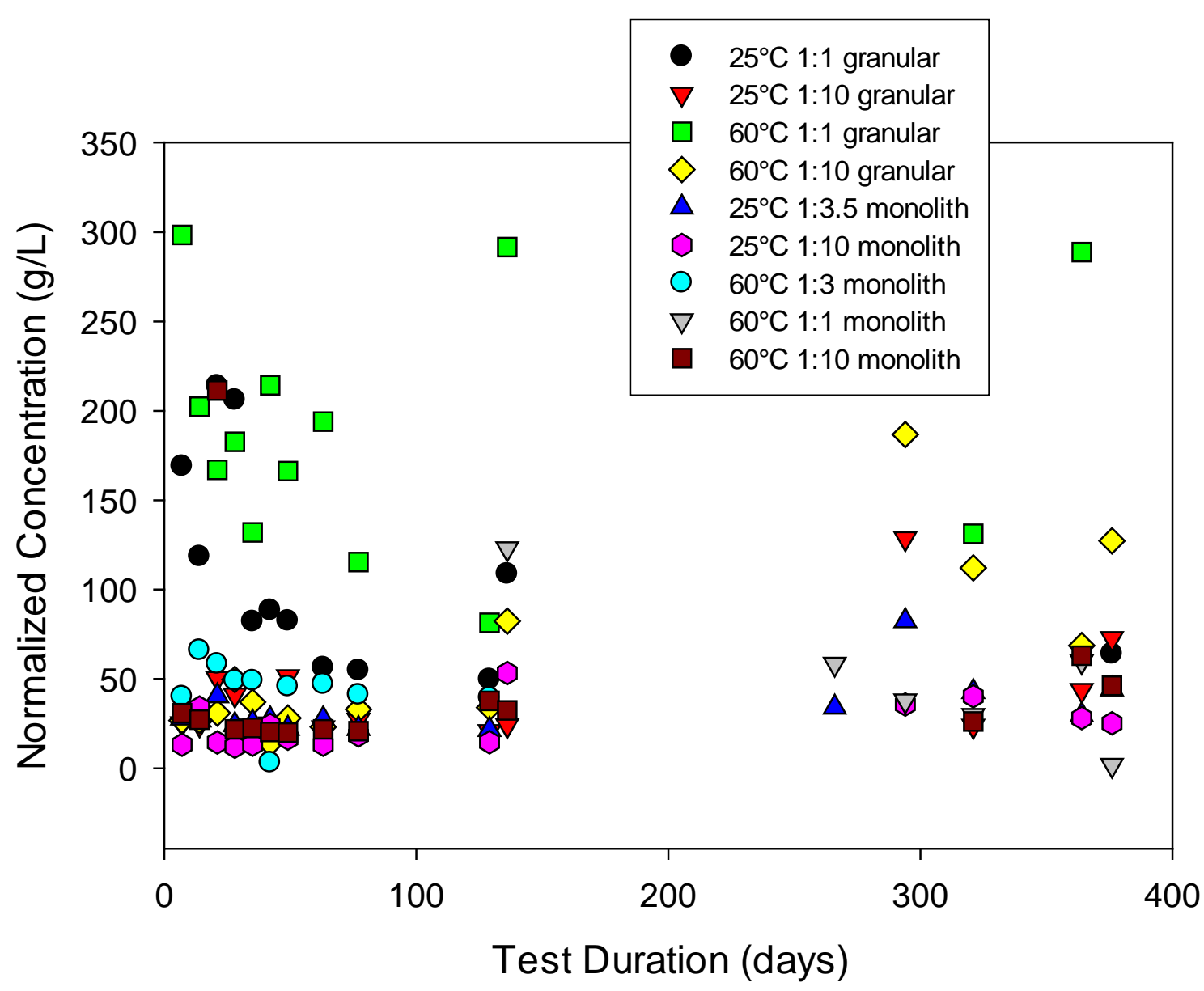

Figure 3.2. PCT results showing the normalized concentrations $(\mathrm{g} / \mathrm{L}$ ) of iodine over the test duration (in days) for the iodine-spiked monolith and granular samples

\subsection{Results From the Technetium Granular and Monolith Samples}

\subsubsection{Technetium Experiment PCT Results}

Figure 3.3 summarizes the PCT data for the technetium-spiked granular and monolith samples at different temperatures and surface-area-to-solution volume ratios. The technetium release was highest for the granular $1: 1$ solid-to-solution ratio at $60^{\circ} \mathrm{C}$ followed by the $1: 10$ monolith, the $1: 1$ granular, and the 1:1 monolith samples at $25^{\circ} \mathrm{C}$. The technetium-spiked samples also displayed an increase in the normalized calcium and sodium concentrations (Figure 3.4 and Figure 3.5). The highest normalized calcium was found in the granular $1: 10$ at $60^{\circ} \mathrm{C}$ followed by the granular $1: 10$ at $25^{\circ} \mathrm{C}$, granular $1: 1$ at $60^{\circ} \mathrm{C}$, and the $1: 10$ monolith sample at $60^{\circ} \mathrm{C}$. The normalized sodium concentrations at both temperatures for the granular 1:1 ratio exhibited the highest values where the 1:10 granular samples at both temperatures were much lower. 


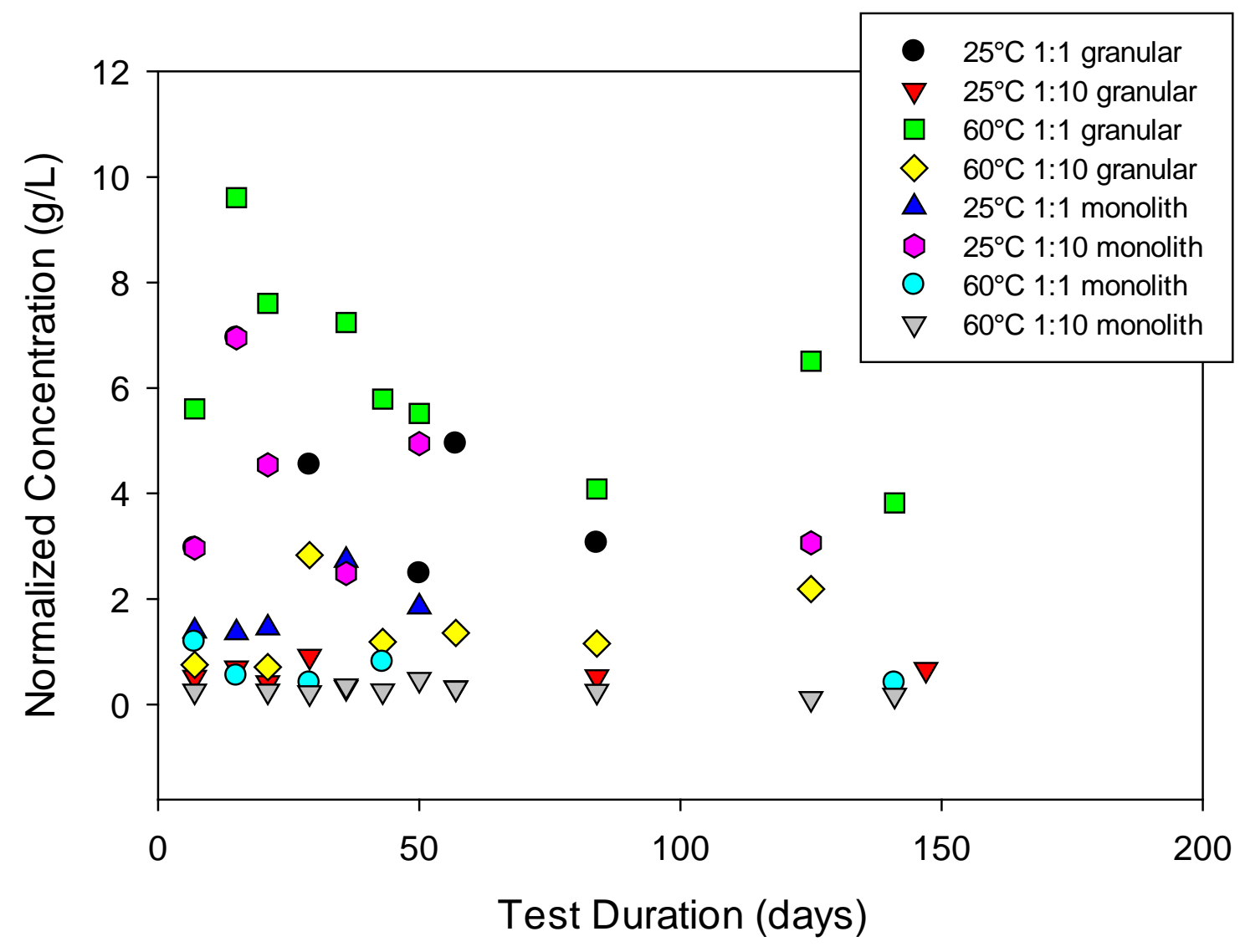

Figure 3.3. PCT results showing the normalized concentrations (g/L) of technetium over the test duration (in days) for the technetium-spiked monolith and granular samples 


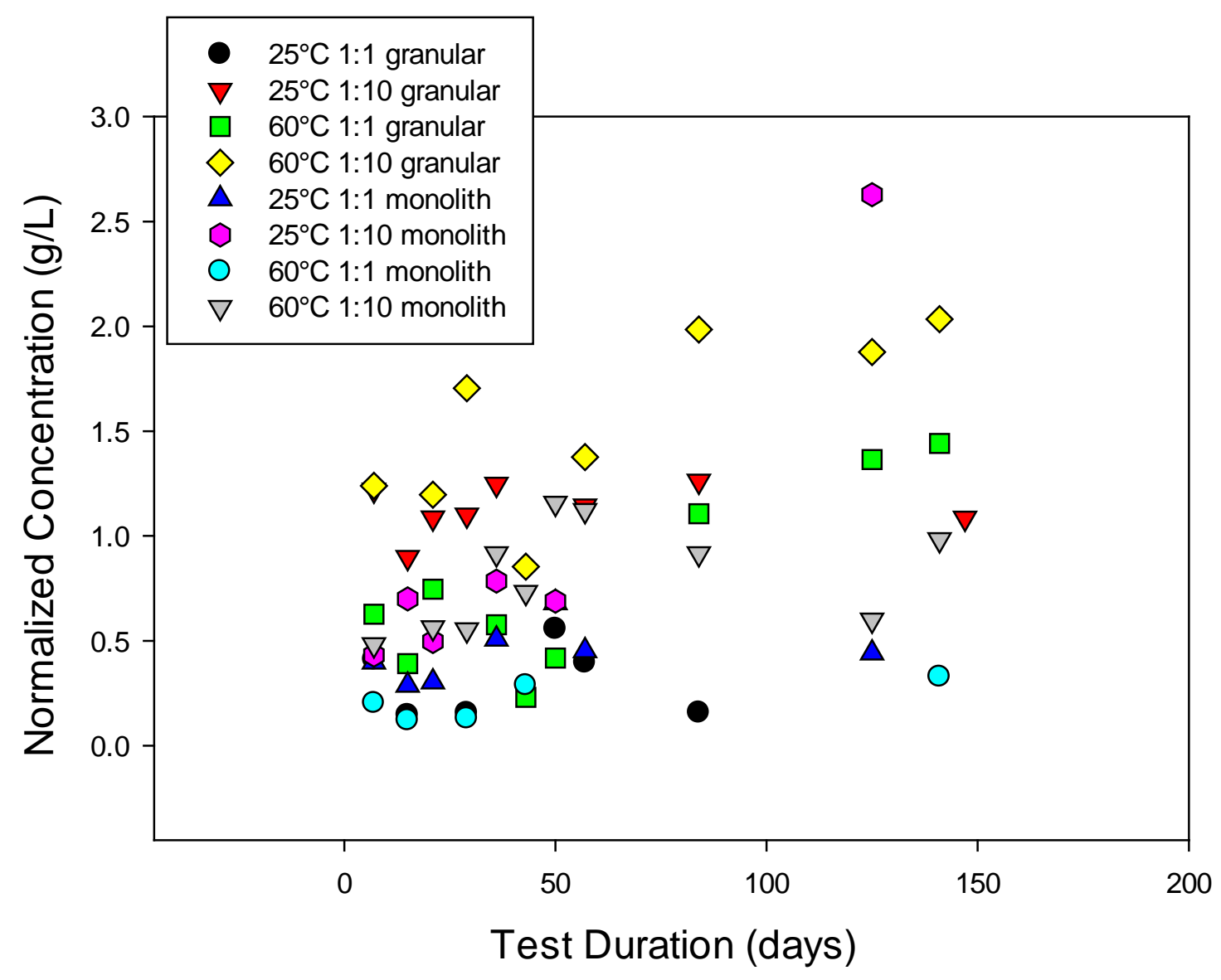

Figure 3.4. PCT results showing the normalized concentrations $(\mathrm{g} / \mathrm{L})$ of calcium over the test duration (in days) for the technetium-spiked monolith and granular samples 


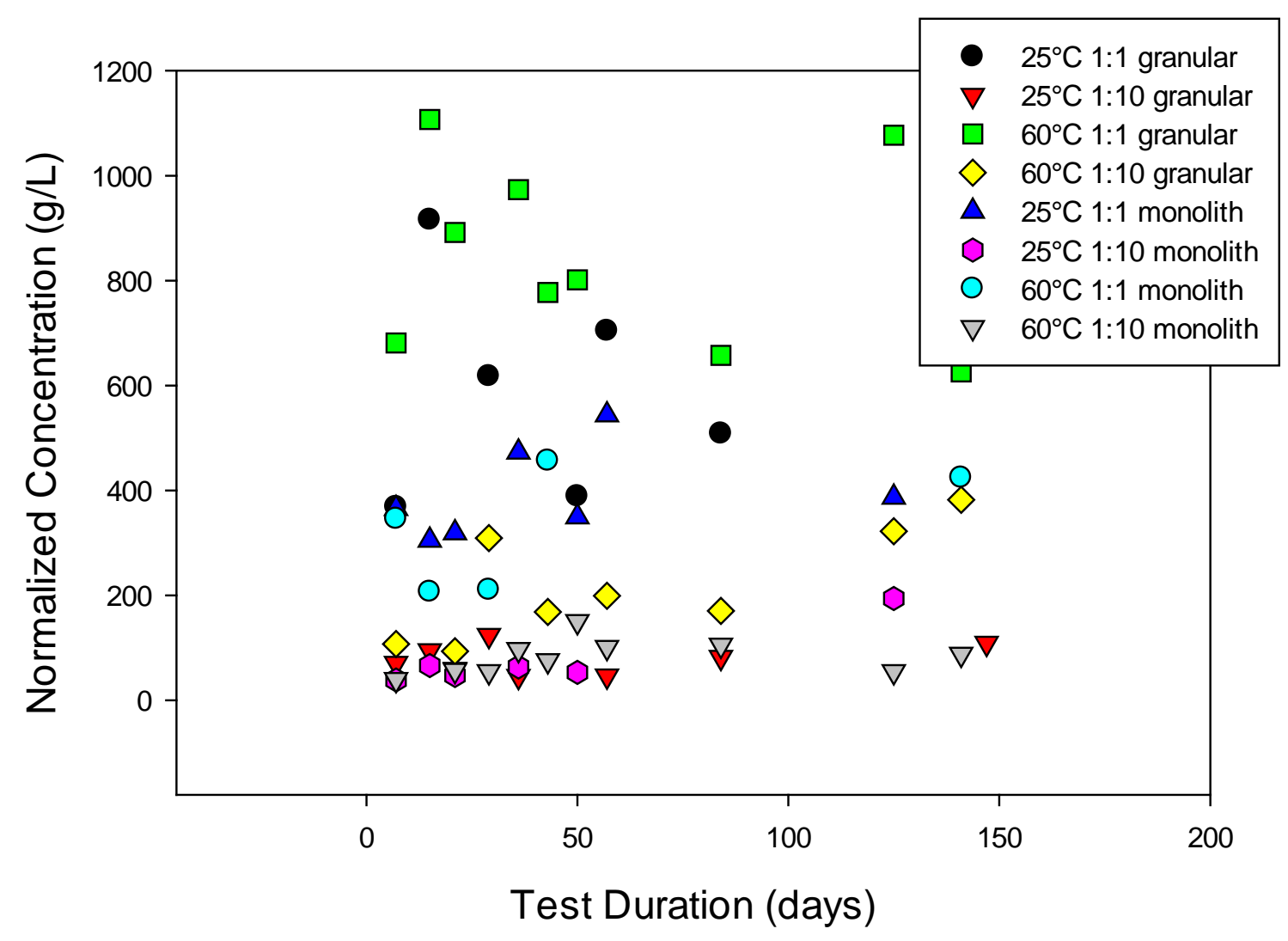

Figure 3.5. PCT results showing the normalized concentrations $(\mathrm{g} / \mathrm{L})$ of sodium over the test duration (in days) for the technetium-spiked monolith and granular samples

\subsubsection{SEM/EDS Analysis}

The granular technetium-spiked samples were analyzed by SEM/EDS analysis by Florida International University. The results, which include multiple images from the same sample, are displayed in Figure 3.6 through Figure 3.17. The EDS analysis shows a dominance of calcium, silica, iron, magnesium, and aluminum in the samples.

\subsubsection{SEM/EDS Results from Technetium Granular Sample, $1: 1$ at $25^{\circ} \mathrm{C}$}

Images and SEM/EDS results for the technetium-spiked granular sample, 1:1 solid-to-solution ratio, at $25^{\circ} \mathrm{C}$, are provided in this section. 

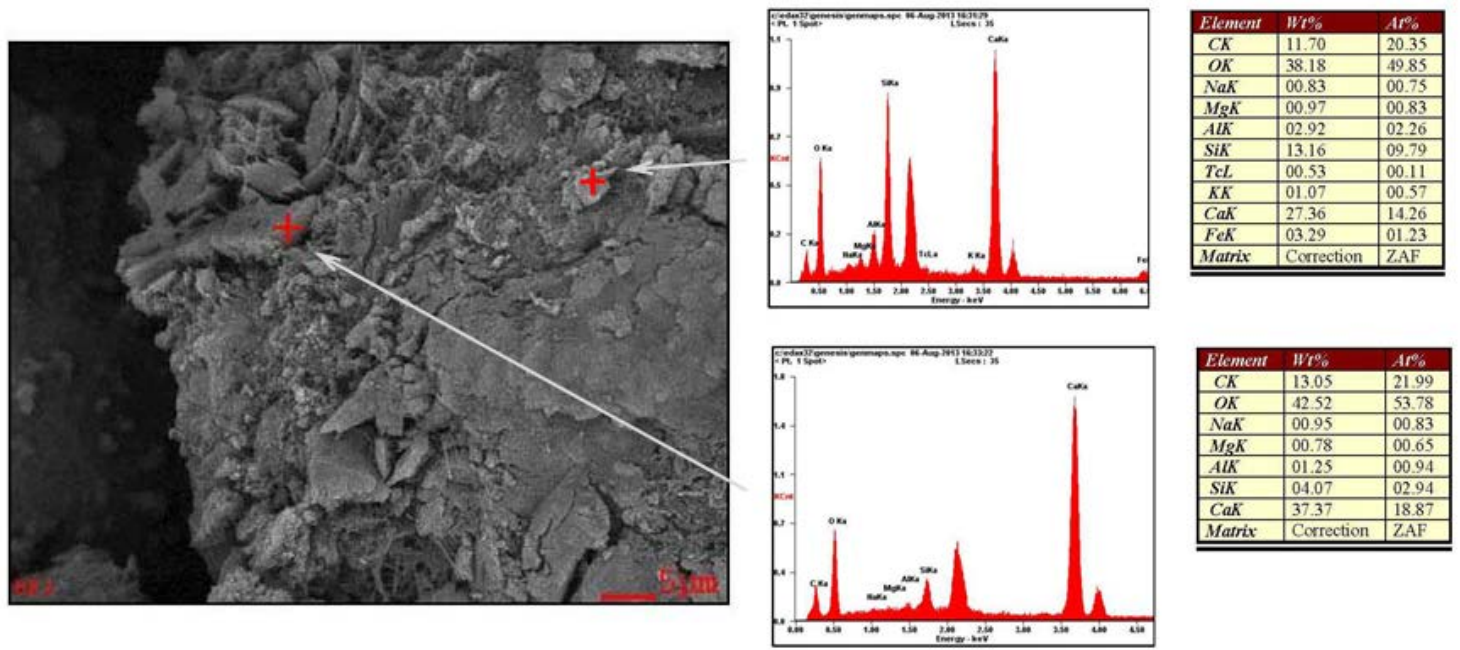

Figure 3.6. SEM and EDS analysis results for the technetium-spiked granular sample, 1:1 solid-tosolution ratio conducted at $25^{\circ} \mathrm{C}$
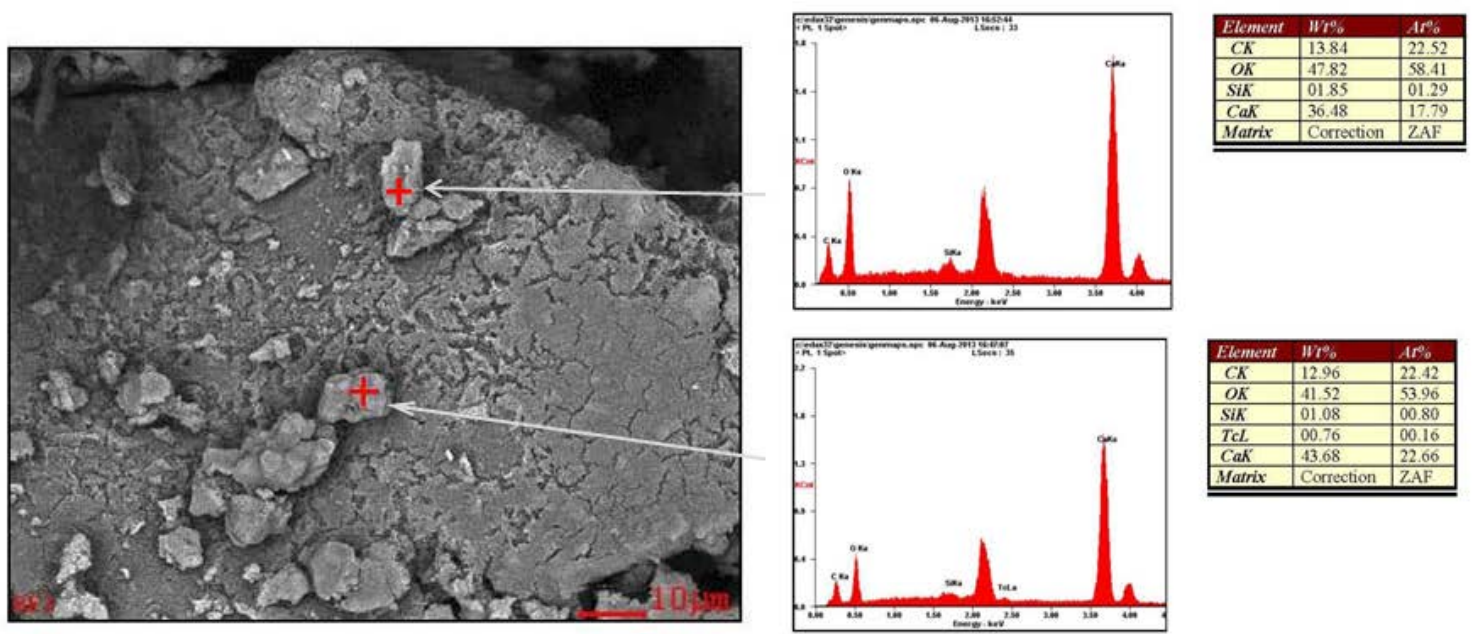

Figure 3.7. SEM and EDS analysis results for the technetium-spiked granular sample, 1:1 solid-tosolution ratio conducted at $25^{\circ} \mathrm{C}$ 

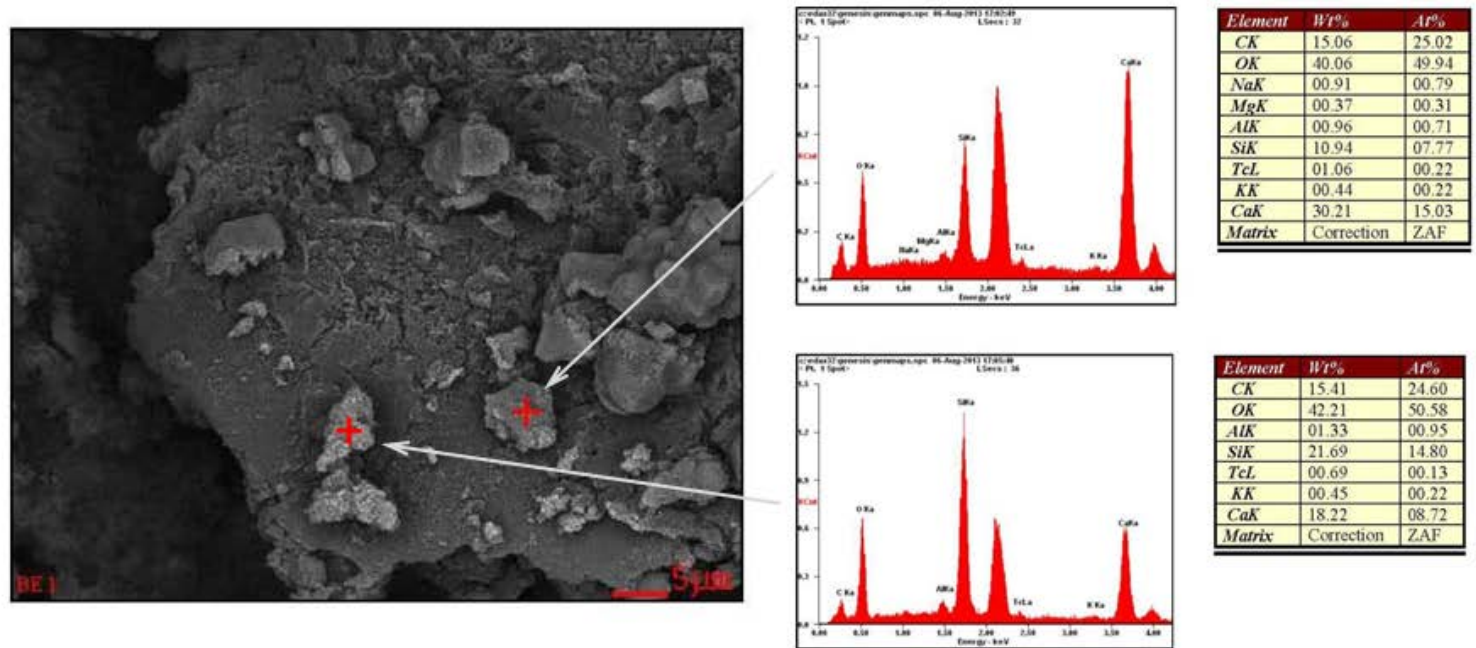

Figure 3.8. SEM and EDS analysis results for the technetium-spiked granular sample, 1:1 solid-tosolution ratio conducted at $25^{\circ} \mathrm{C}$
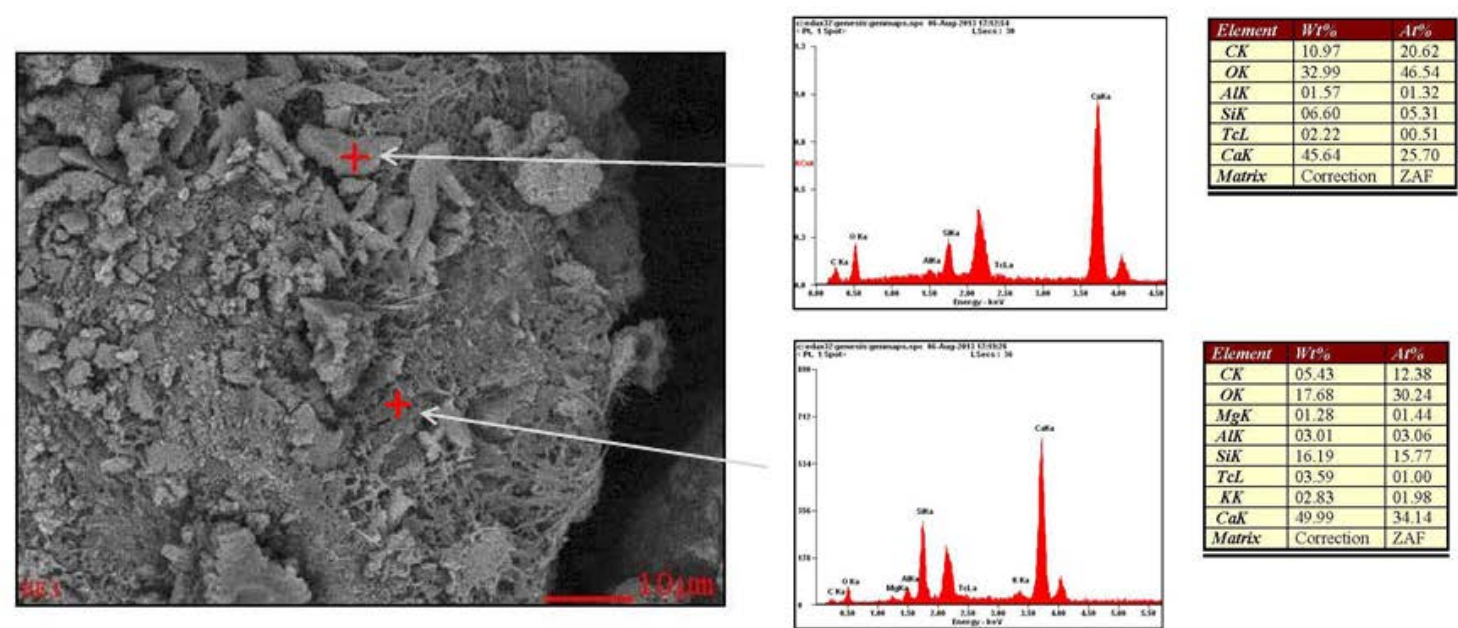

Figure 3.9. SEM and EDS analysis results for the technetium-spiked granular sample, 1:1 solid-tosolution ratio conducted at $25^{\circ} \mathrm{C}$ 


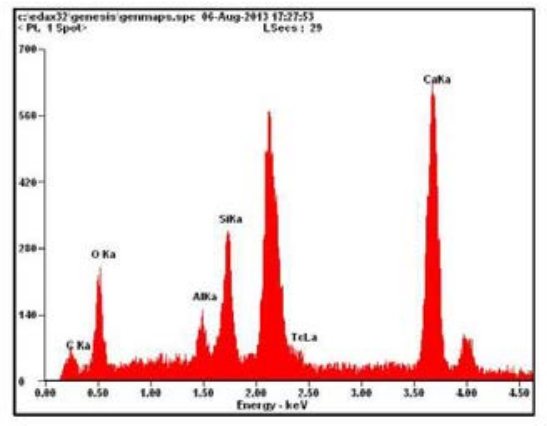

\begin{tabular}{|l|l|l|}
\hline Element & $W t^{\%}$ & $A t^{\%}$ \\
\hline$C K$ & 10.81 & 19.97 \\
\hline$O K$ & 34.74 & 48.16 \\
\hline$A L K$ & 03.41 & 02.81 \\
\hline SiK & 10.09 & 07.97 \\
\hline$T c L$ & 01.95 & 00.44 \\
\hline$C a K$ & 33.36 & 18.46 \\
\hline FeK & 03.95 & 01.57 \\
\hline CoK & 01.67 & 00.63 \\
\hline Matrix & Correction & ZAF \\
\hline \hline
\end{tabular}

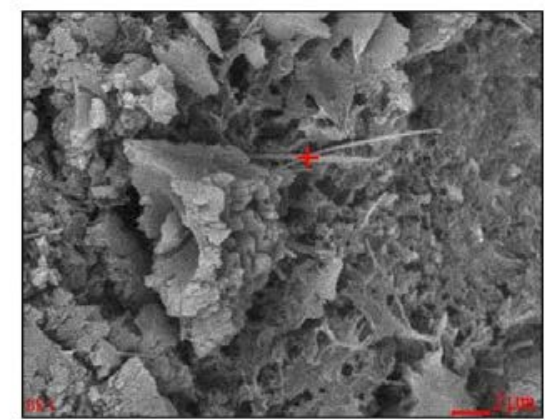

Figure 3.10. SEM and EDS analysis results for the technetium-spiked granular sample, 1:1 solid-tosolution ratio conducted at $25^{\circ} \mathrm{C}$

\subsubsection{SEM/EDS Results from Technetium Granular Sample, 1:10 at $25^{\circ} \mathrm{C}$}

Images and SEM/EDS results for the technetium-spiked granular sample, 1:10 solid-to-solution ratio, at $25^{\circ} \mathrm{C}$, are provided in this section. 

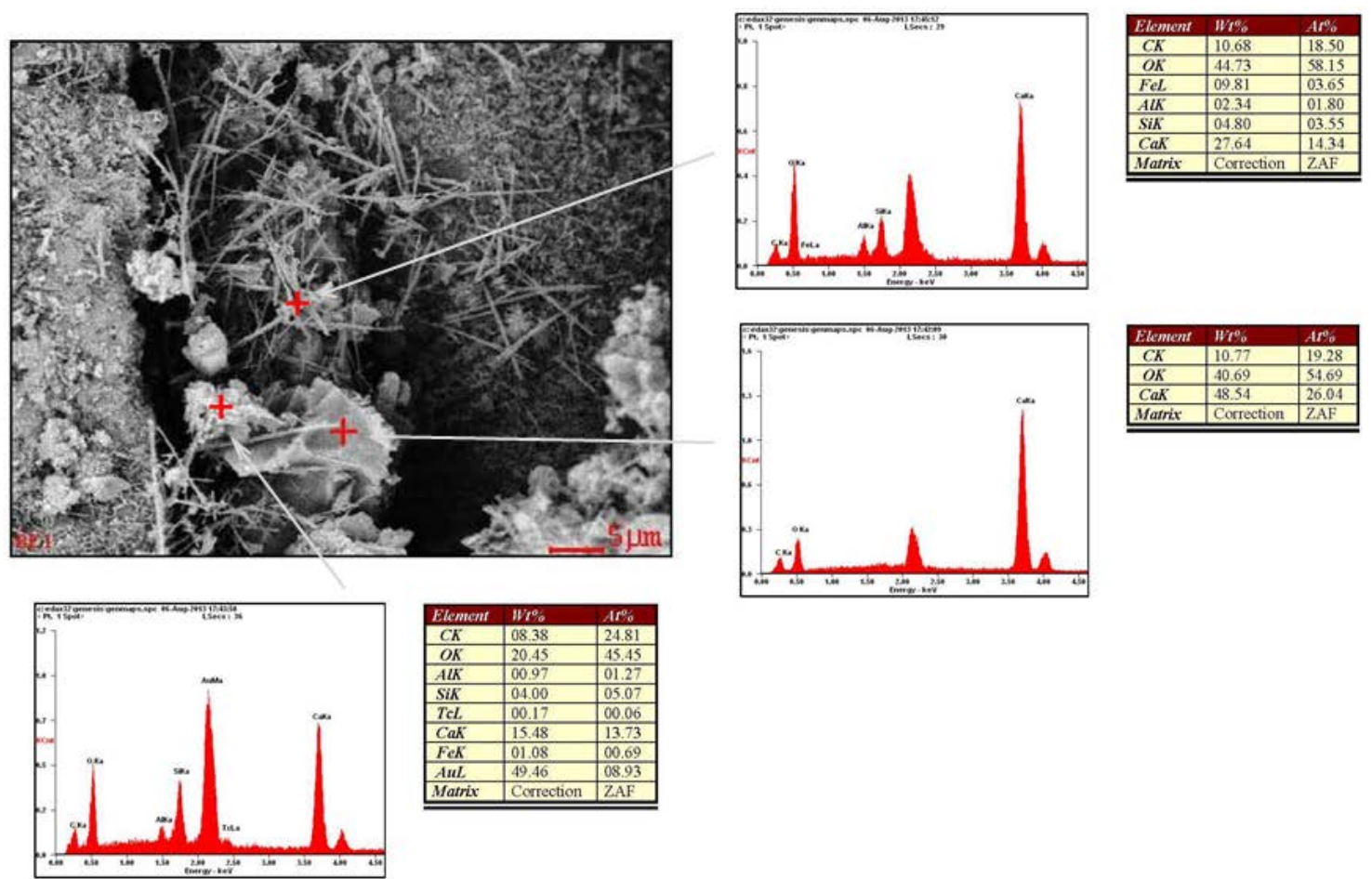

Figure 3.11. SEM/EDS analysis results for technetium-spiked granular sample, 1:10 solid-to-solution ratio conducted at $25^{\circ} \mathrm{C}$ 

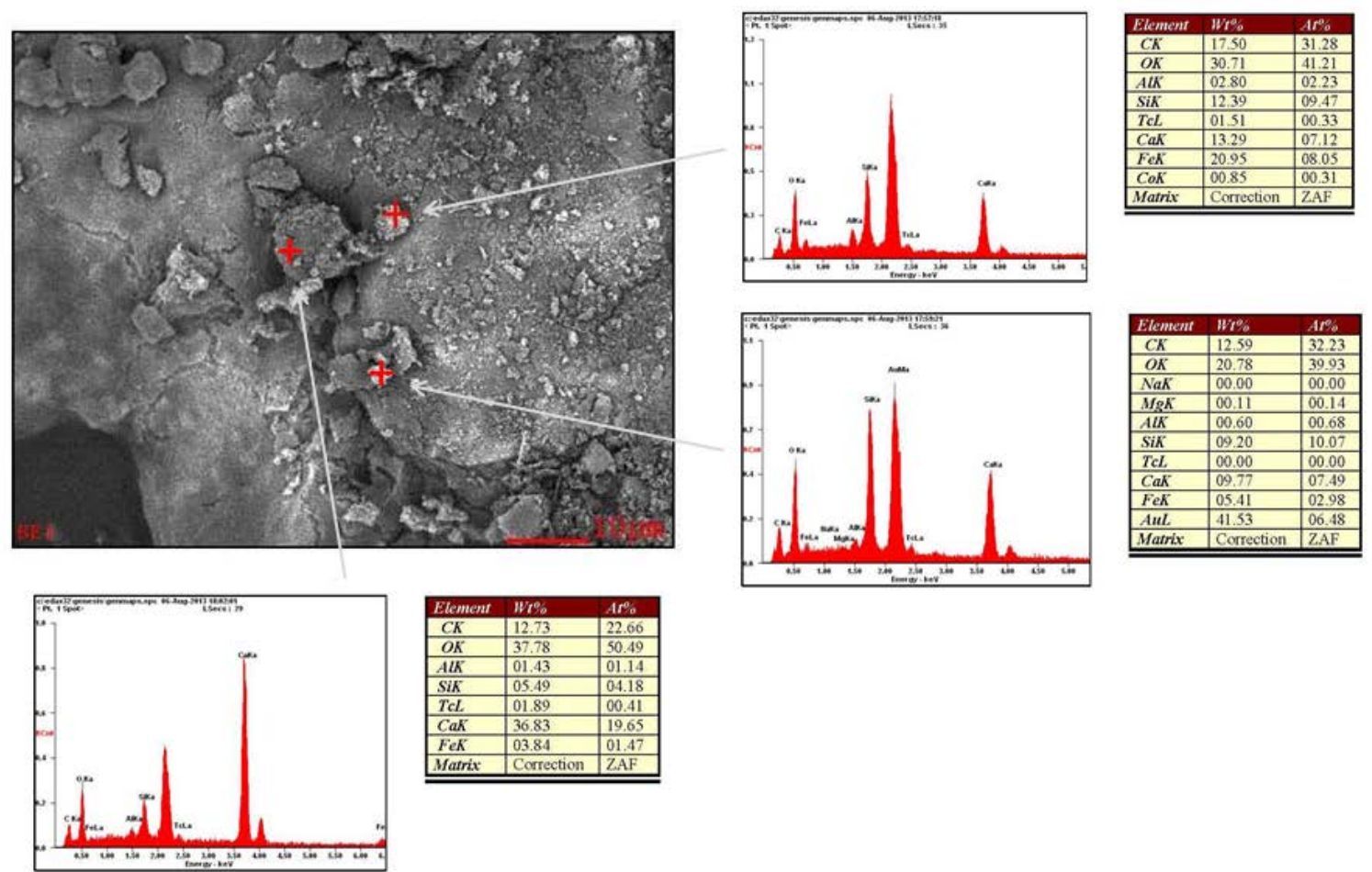

Figure 3.12. SEM/EDS analysis results for technetium-spiked granular sample, 1:10 solid-to-solution ratio conducted at $25^{\circ} \mathrm{C}$
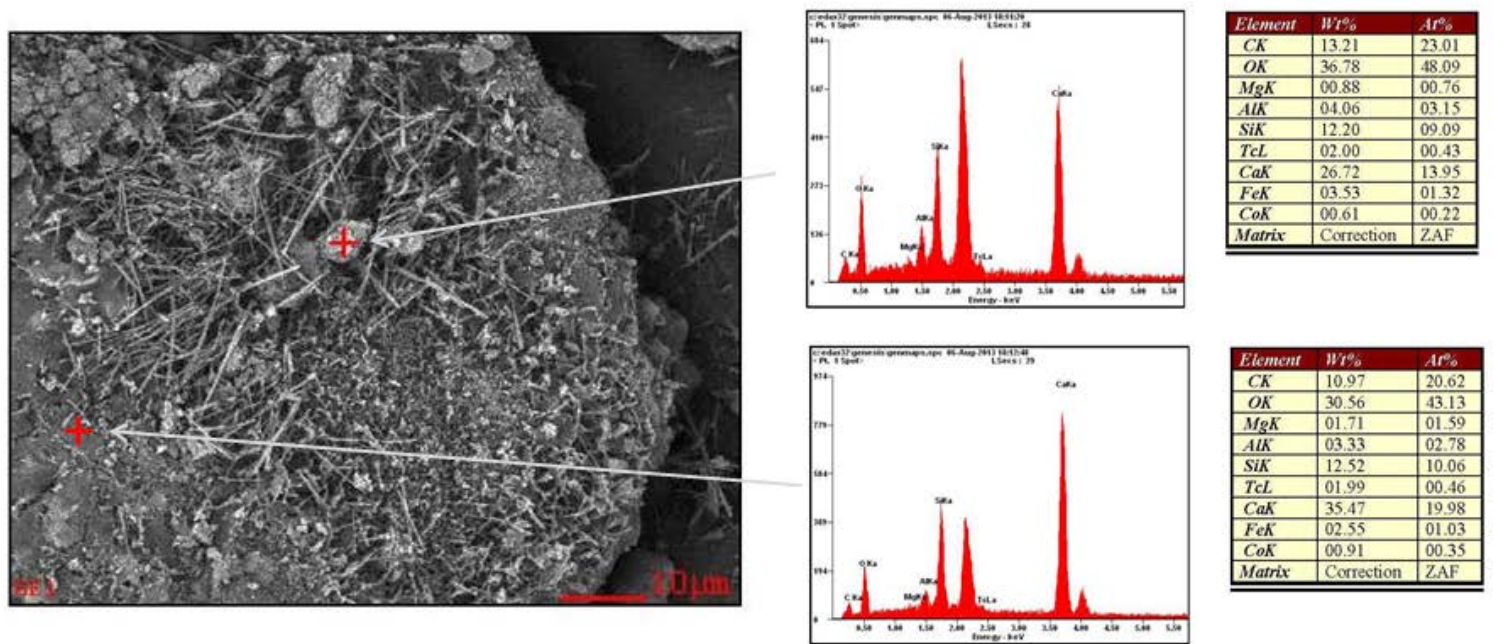

Figure 3.13. SEM/EDS analysis results for technetium-spiked granular sample, 1:10 solid-to-solution ratio conducted at $25^{\circ} \mathrm{C}$ 


\subsubsection{SEM/EDS Results from Technetium Granular Sample, $1: 1$ at $60^{\circ} \mathrm{C}$}

Images and SEM/EDS results for the technetium-spiked granular sample, 1:1 solid-to-solution ratio, at $60^{\circ} \mathrm{C}$, are provided in this section.

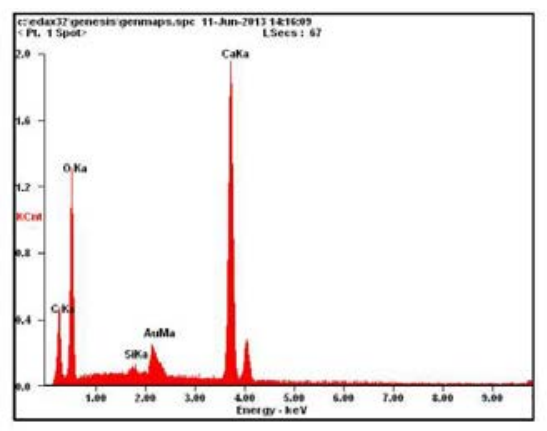

\begin{tabular}{|l|l|l|}
\hline Element & Wt $\%$ & At $\%$ \\
\hline CK & 15.76 & 25.41 \\
\hline OK & 49.67 & 60.12 \\
\hline SiK & 00.48 & 00.33 \\
\hline AuM & 06.06 & 00.60 \\
\hline CaK & 28.02 & 13.54 \\
\hline Matrix & Correction & ZAF \\
\hline \hline
\end{tabular}

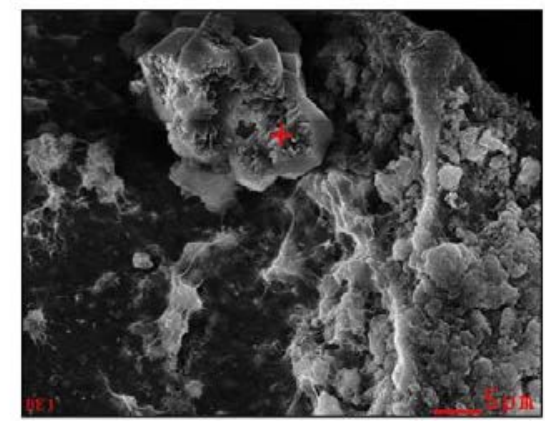

Figure 3.14. SEM/EDS analysis results for technetium-spiked granular sample, 1:1 solid-to-solution ratio conducted at $60^{\circ} \mathrm{C}$ 


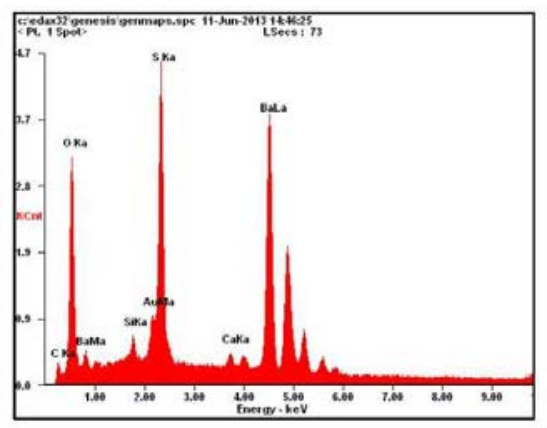

\begin{tabular}{|l|l|l|}
\hline Element & $W t^{\%}$ & $A t \%$ \\
\hline$C K$ & 04.24 & 14.48 \\
\hline$O K$ & 18.81 & 48.19 \\
\hline SiK & 01.10 & 01.60 \\
\hline$A u M$ & 06.84 & 01.42 \\
\hline$S K$ & 13.38 & 17.10 \\
\hline CaK & 00.83 & 00.85 \\
\hline BaL & 54.80 & 16.35 \\
\hline Matrix & Correction & ZAF \\
\hline \hline
\end{tabular}

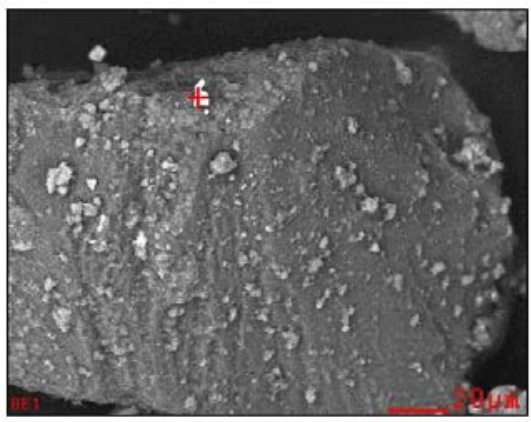

Figure 3.15. SEM/EDS analysis results for technetium-spiked granular sample, 1:1 solid-to-solution ratio conducted at $60^{\circ} \mathrm{C}$

\subsubsection{SEM/EDS Results from Technetium Granular Sample, 1:10 at $60^{\circ} \mathrm{C}$}

Images and SEM/EDS results for the technetium-spiked granular sample, 1:10 solid-to-solution ratio, at $60^{\circ} \mathrm{C}$, are provided in this section. 


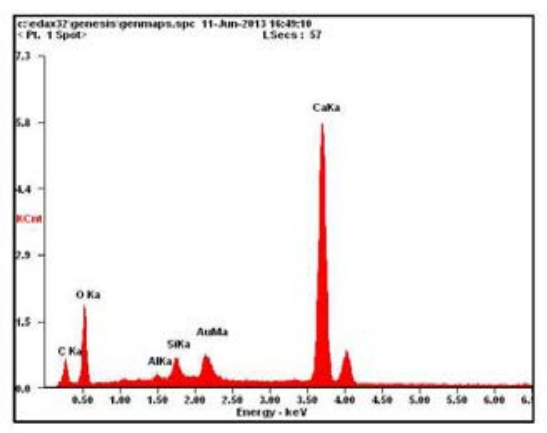

\begin{tabular}{|l|l|l|}
\hline Element & Wt $\%$ & $A t \%$ \\
\hline CK & 10.12 & 19.41 \\
\hline OK & 37.29 & 53.71 \\
\hline$A I K$ & 00.69 & 00.59 \\
\hline SiK & 02.39 & 01.96 \\
\hline AuM & 09.02 & 01.05 \\
\hline CaK & 40.49 & 23.28 \\
\hline Matrix & Correction & ZAF \\
\hline
\end{tabular}

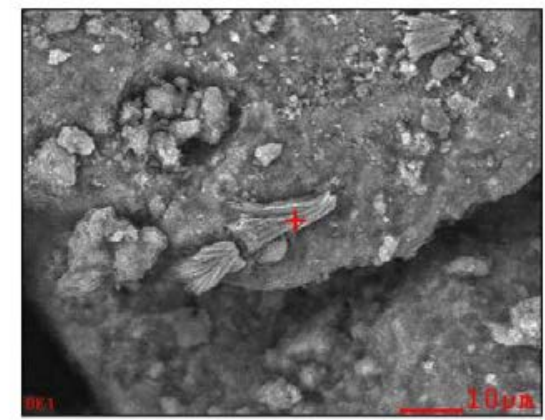

Figure 3.16. SEM/EDS analysis results for technetium-spiked granular sample, 1:10 solid-to-solution ratio conducted at $60^{\circ} \mathrm{C}$

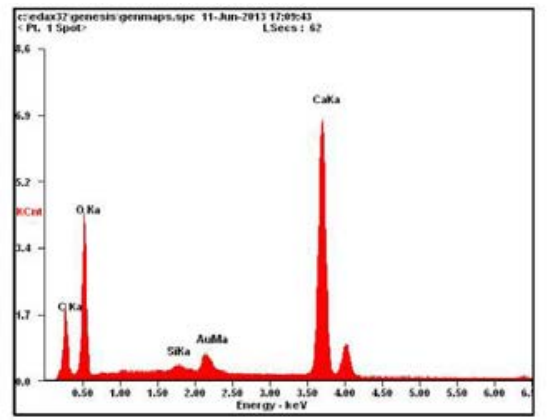

\begin{tabular}{|l|l|l|}
\hline Element & Wt\% & At\% \\
\hline CK & 16.94 & 26.97 \\
\hline OK & 48.81 & 58.33 \\
\hline SiK & 00.41 & 00.28 \\
\hline AuM & 04.52 & 00.44 \\
\hline CaK & 29.33 & 13.99 \\
\hline Matrix & Correction & ZAF \\
\hline \hline
\end{tabular}

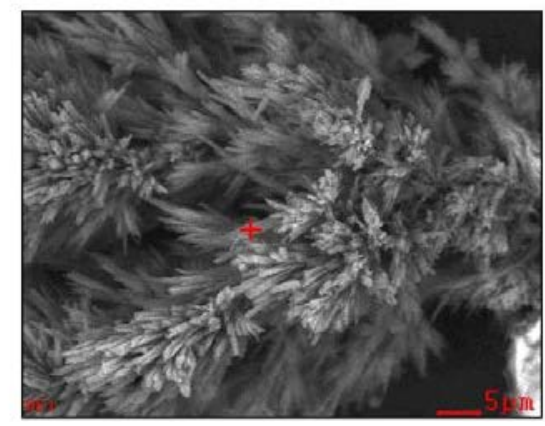

Figure 3.17. SEM/EDS analysis results for technetium-spiked granular sample, 1:10 solid-to-solution ratio conducted at $60^{\circ} \mathrm{C}$ 


\subsubsection{XRD Analysis}

After the SEM-EDS analysis was complete, the granular technetium-spiked samples were analyzed via XRD. Results for the Tc-containing samples are shown in Figure 3.18 through Figure 3.21. The XRD analysis confirmed the presence of calcium and silica bearing minerals. Specifically ettringite was found in both $25^{\circ} \mathrm{C}$ samples.

\subsubsection{XRD Results from Technetium Granular Sample, 1:1 at $25^{\circ} \mathrm{C}$}

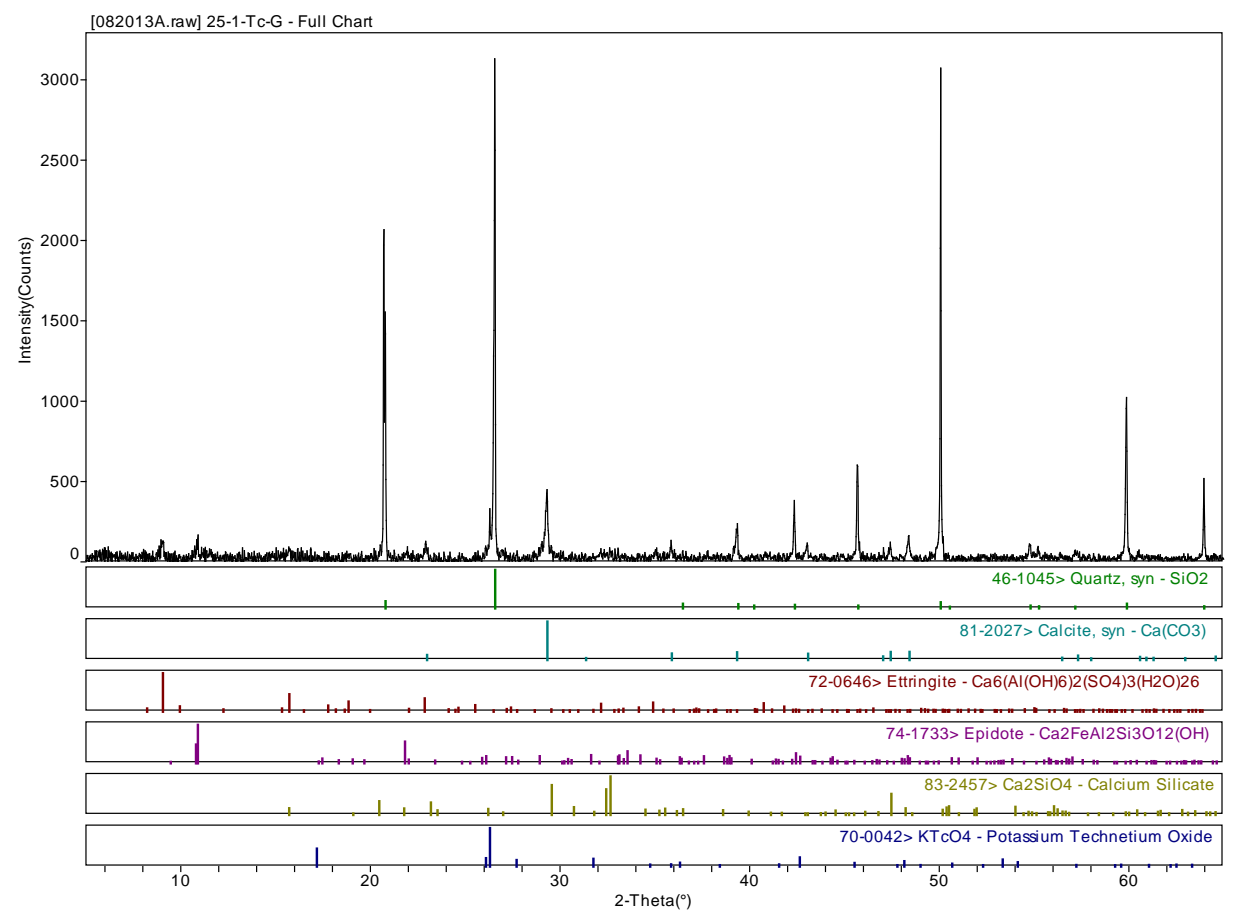

Figure 3.18. XRD results for technetium-spiked granular sample, 1:1 solid-to-solution ratio conducted at $25^{\circ} \mathrm{C}$ 


\subsubsection{XRD Results from Technetium Granular Sample, 1:10 at $25^{\circ} \mathrm{C}$}

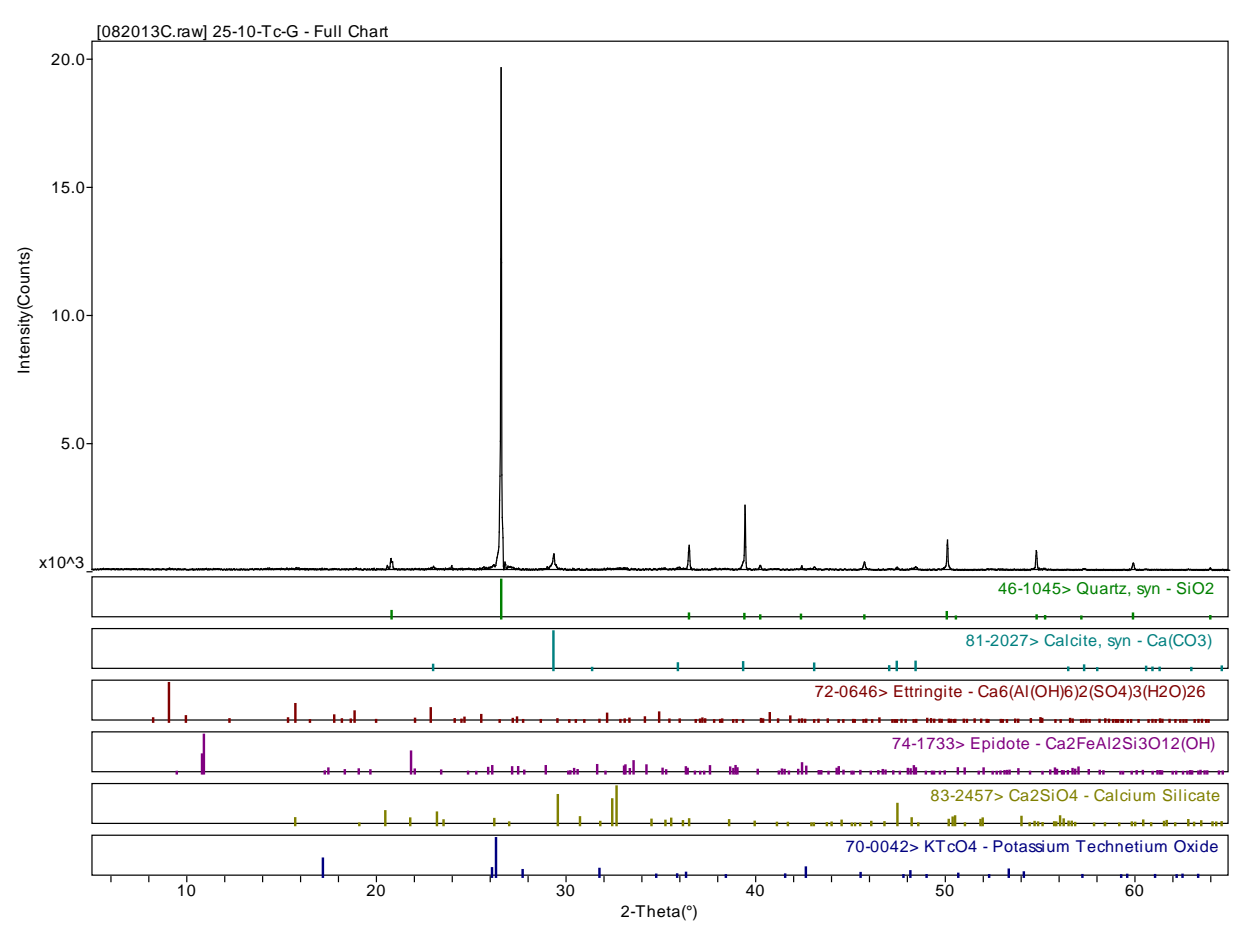

Figure 3.19. XRD results for technetium-spiked granular sample, 1:10 solid-to-solution ratio conducted at $25^{\circ} \mathrm{C}$. 


\subsubsection{XRD Results from Technetium Granular Sample, 1:1 at $60^{\circ} \mathrm{C}$}

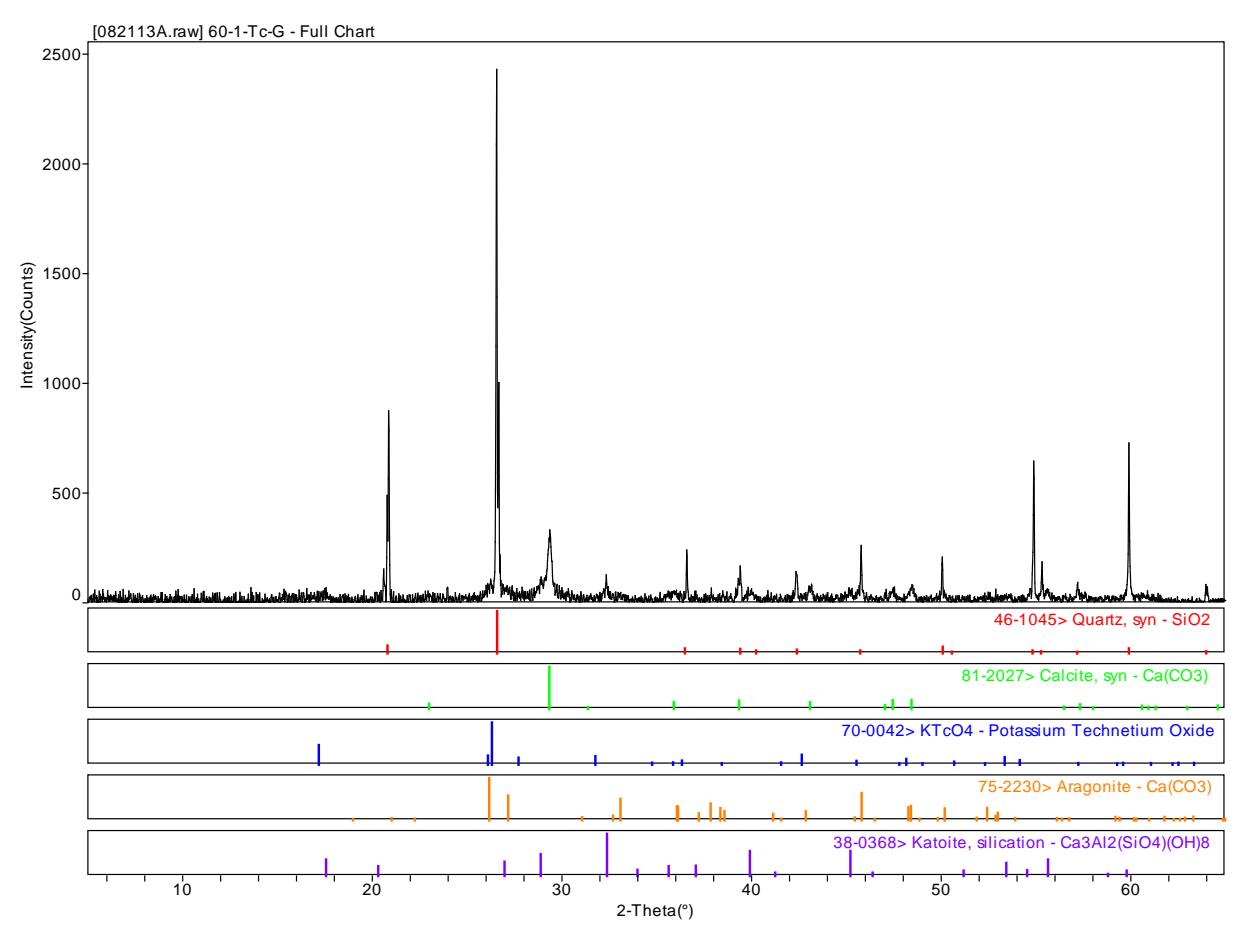

Figure 3.20. XRD results for technetium-spiked granular sample, $1: 1$ solid-to-solution ratio conducted at $60^{\circ} \mathrm{C}$ 


\subsubsection{XRD Results from Technetium Granular Sample, 1:10 at $60^{\circ} \mathrm{C}$}

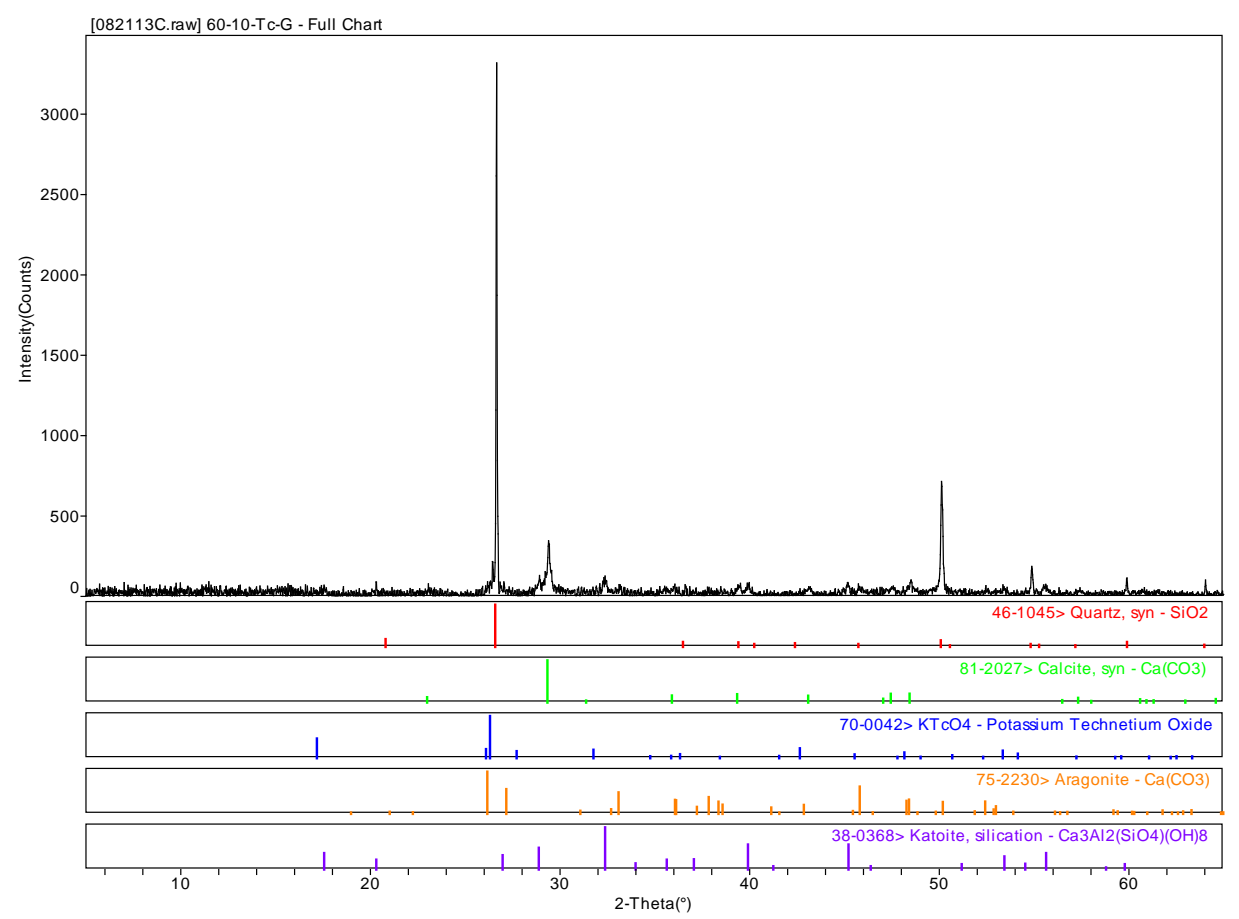

Figure 3.21. XRD results for technetium-spiked granular sample, 1:10 solid-to-solution ratio conducted at $60^{\circ}$

\subsection{Technetium-Spiked Sample Results and Discussion}

The XRD and SEM analysis both confirm the presence of secondary precipitate minerals. The XRD analyses confirm the presence of secondary precipitate minerals ettringite, quartz, calcite, epidote and calcium silicate in both $25^{\circ} \mathrm{C}$ granular samples. The quartz and calcite are both also found in the granular $60^{\circ} \mathrm{C}$ samples, but different than the $25^{\circ} \mathrm{C}$, they have aragonite and katoite silication. These results confirm the formation of different secondary phases at the higher temperature. The SEM images of the reacted granular samples also show secondary phases. Specifically, a needle-like crystalline phase is visible in the foreground of Figure 3.11 and Figure 3.13 that is likely the ettringite that we also see in the XRD scan. These results are consistent with previous concrete work that found ettringite was a secondary phase found to form on the surface of the concrete post-reaction. Other crystalline secondary phases are visible in SEM scans shown in Figure 3.16 and Figure 3.17 where a feather-like crystalline calcium oxide is visible. In Figure 3.14 the formation of a calcium-rich amorphous material is visible in the scan. The Ca-rich amorphous material in the scan is not calcite because we know calcite has a rhombohedral shape. The Ca-rich amorphous material seen in the SEM image likely is not visible in the XRD due to small concentrations found in the sample. XRD provides preliminary information on the possible secondary phases that form, but it is limited on phases that are present at $<5 \mathrm{wt} \%$.

The higher normalized concentration of calcium ( $<3 \mathrm{~g} / \mathrm{L}$ ) compared to sodium ( $<973 \mathrm{~g} / \mathrm{L})$ found in the PCT tests suggests that the calcium may be getting sequestered in the formation of secondary phases, resulting in lower concentrations of calcium. This is supported by the EDS analysis, which resulted in high concentrations of calcium, as well as calcium-rich minerals detected by XRD, such as calcite. 


\subsection{Results from the Uranium Granular and Monolith Samples}

\subsubsection{Uranium PCT Experiment Results}

Figure 3.22 summarizes the PCT data for the uranium-spiked granular and monolith samples at different temperatures and surface-area-to-solution volume ratios. Consistent with the iodine and technetium tests, the uranium release was highest for the $1: 1$ solid-to-solution ratio at $60^{\circ} \mathrm{C}$. The $1: 10$ granular samples, however, at both temperatures, resulted in some of the lowest normalized concentrations. The normalized release for calcium and sodium is displayed in Figure 3.23 and Figure 3.24. Some of the highest normalized calcium concentrations were measured in the monolith samples. Specifically, the monolith samples at both temperatures and 1:10 ratios resulted in the highest normalized concentrations. Conversely, the $60^{\circ} \mathrm{C} 1: 1$ monolith and granular samples as well as the $25^{\circ} \mathrm{C} 1: 1$ granular samples had the lowest normalized concentrations of calcium. Similar to the technetium-spiked concrete samples, the sodium concentrations were highest in the granular 1:1 sample at both temperatures.

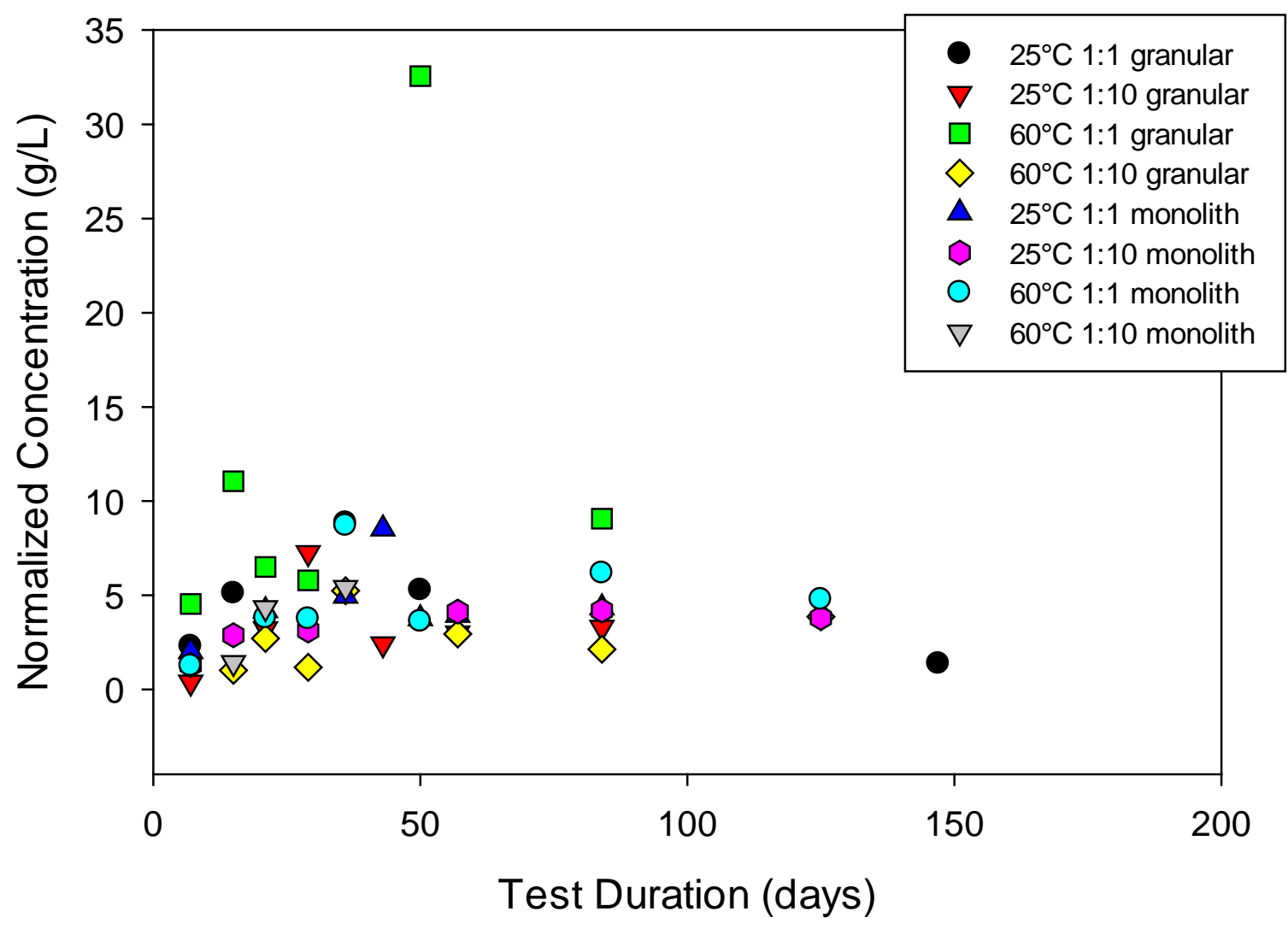

Figure 3.22. PCT results showing the normalized concentrations $(\mathrm{g} / \mathrm{L})$ of uranium over the test duration (in days) for the monolith and granular uranium-spiked samples 


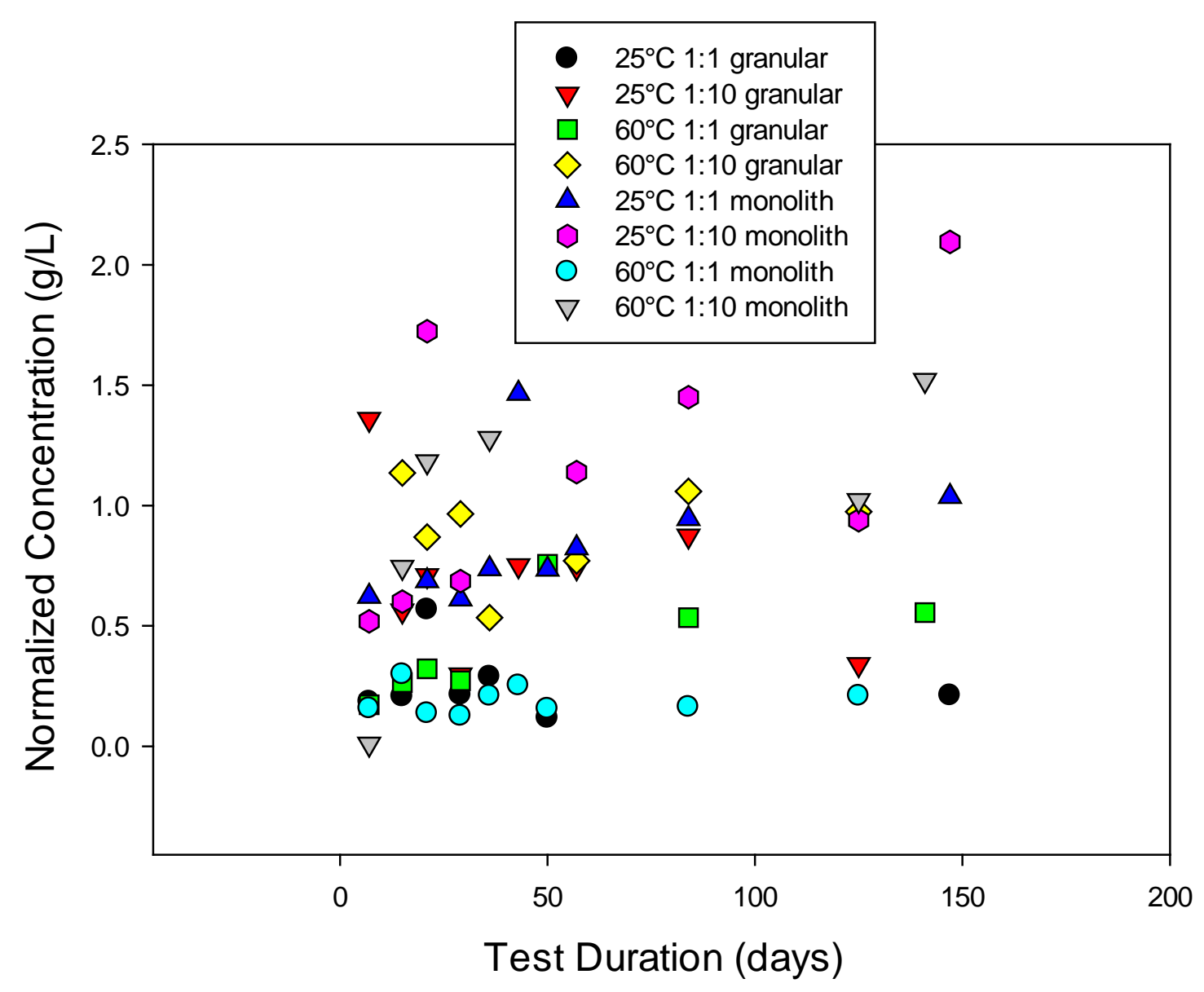

Figure 3.23. PCT results showing the normalized concentrations (g/L) of calcium over the test duration (in days) for the monolith and granular uranium-spiked samples 


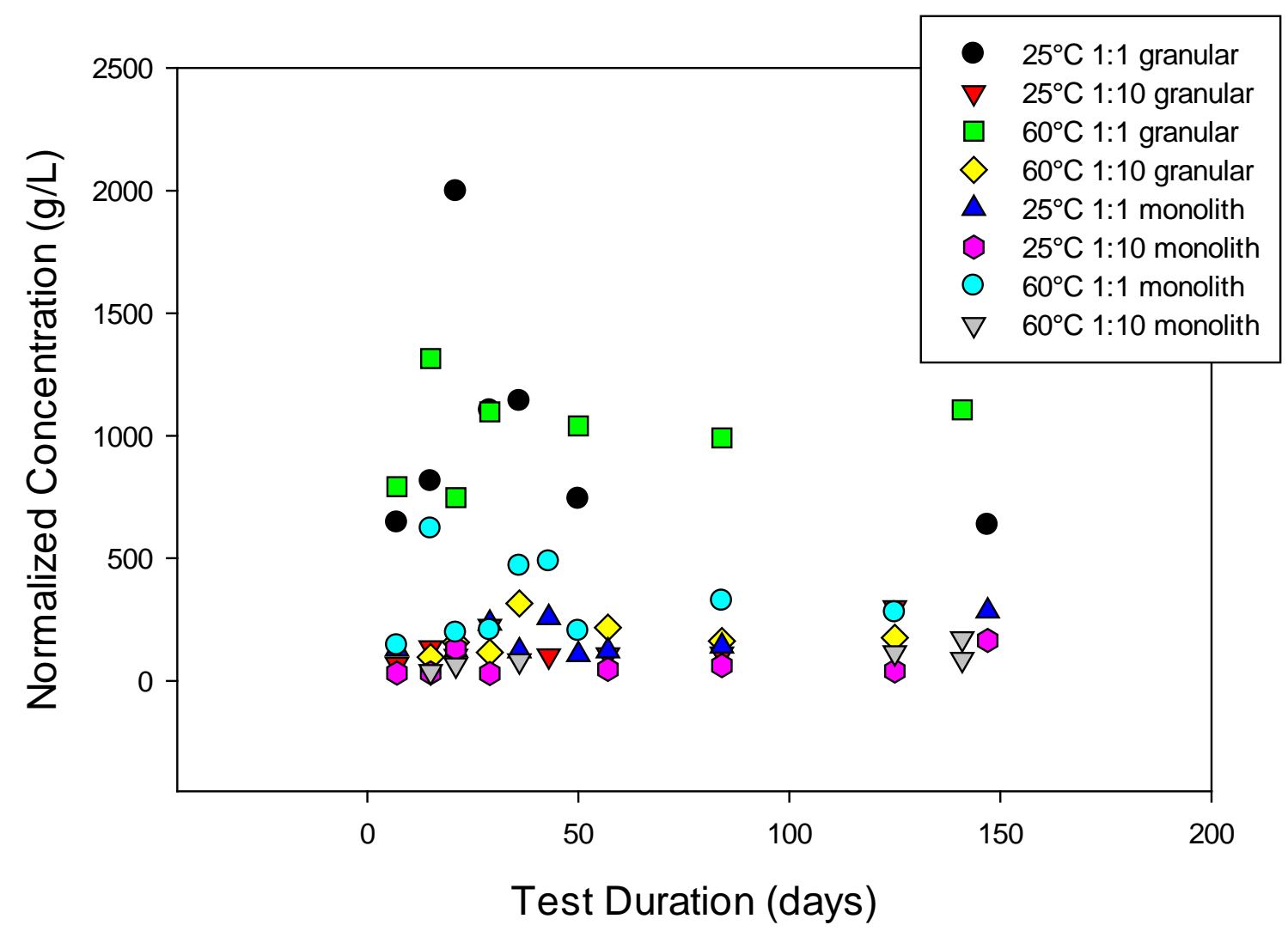

Figure 3.24. PCT results showing the normalized concentrations $(\mathrm{g} / \mathrm{L})$ of sodium over the test duration (in days) for the monolith and granular uranium-spiked samples

\subsubsection{SEM/EDS Analysis}

The granular and monolith-spiked uranium samples were analyzed by Florida International University for SEM/EDS analysis. The results are displayed in Figure 3.25 through Figure 3.52. Crystalline grains, including needle-like phases, can be seen in the foreground of some of the granular samples. EDS results show these crystalline phases to be dominated by calcium and silica, with lesser amounts of sodium, potassium, aluminum, magnesium, and iron. The monolith samples, however, show more amorphous phases that are dominated by silica, calcium, and iron.

\subsubsection{SEM/EDS Results for Uranium Granular Sample, $1: 1$ at $25^{\circ} \mathrm{C}$}

Images and SEM/EDS results for the uranium-spiked granular sample, 1:1 solid-to-solution ratio, at $25^{\circ} \mathrm{C}$, are provided in this section. 


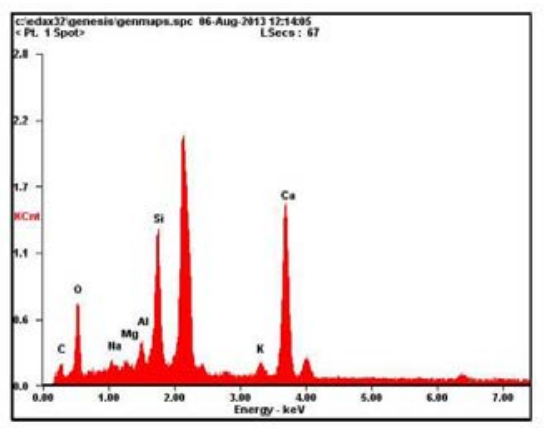

\begin{tabular}{|l|l|l|}
\hline Element & $\boldsymbol{W t}^{\boldsymbol{o}} \%$ & $\mathrm{At} \%$ \\
\hline $\mathrm{CK}$ & 12.04 & 20.82 \\
\hline $\mathrm{OK}$ & 36.81 & 47.80 \\
\hline $\mathrm{NaK}$ & 01.56 & 01.41 \\
\hline $\mathrm{MgK}$ & 00.74 & 00.63 \\
\hline AlK & 02.44 & 01.88 \\
\hline SiK & 15.25 & 11.28 \\
\hline $\mathrm{KK}$ & 02.21 & 01.18 \\
\hline CaK & 28.95 & 15.01 \\
\hline Matrix & Correction & ZAF \\
\hline \hline
\end{tabular}

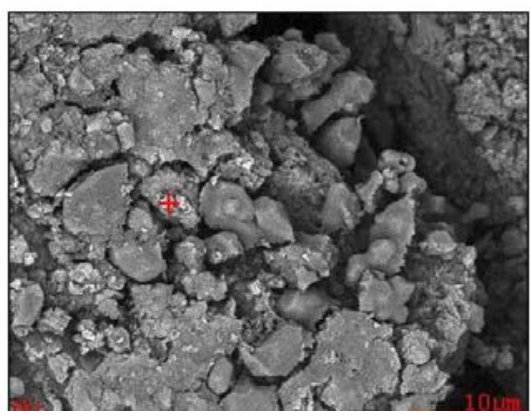

Figure 3.25. SEM/EDS analysis results for uranium-spiked granular sample, 1:1 solid-to-solution ratio conducted at $25^{\circ} \mathrm{C}$

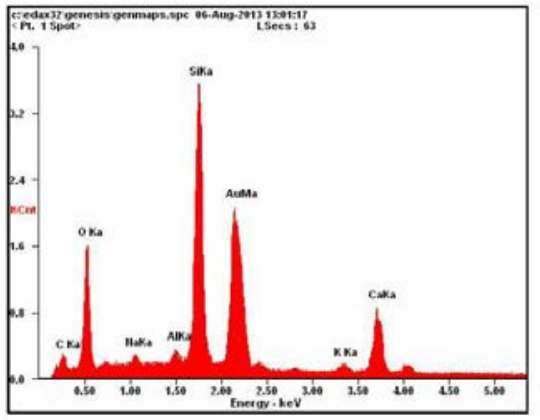

\begin{tabular}{|l|l|l|}
\hline Element & Wt $\%$ & $A t^{\circ}$ \\
\hline$C K$ & 08.04 & 20.48 \\
\hline$O K$ & 24.58 & 46.98 \\
\hline NaK & 00.74 & 00.98 \\
\hline$A I K$ & 00.74 & 00.84 \\
\hline SiK & 16.42 & 17.88 \\
\hline$K K$ & 00.84 & 00.66 \\
\hline $\mathrm{CaK}$ & 06.62 & 05.05 \\
\hline FeK & 01.56 & 00.85 \\
\hline AuL & 40.46 & 06.28 \\
\hline Matrix & Correction & ZAF \\
\hline \hline
\end{tabular}

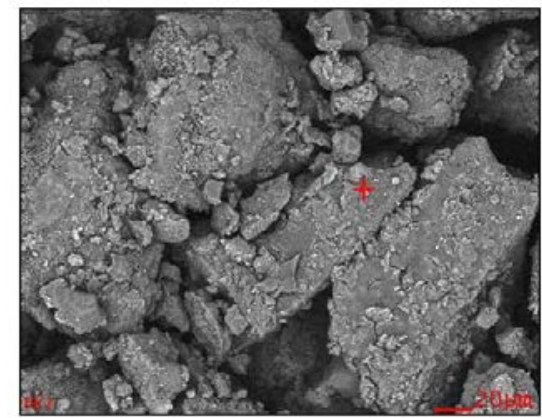

Figure 3.26. SEM/EDS analysis results for uranium-spiked granular sample, 1:1 solid-to-solution ratio conducted at $25^{\circ} \mathrm{C}$ 


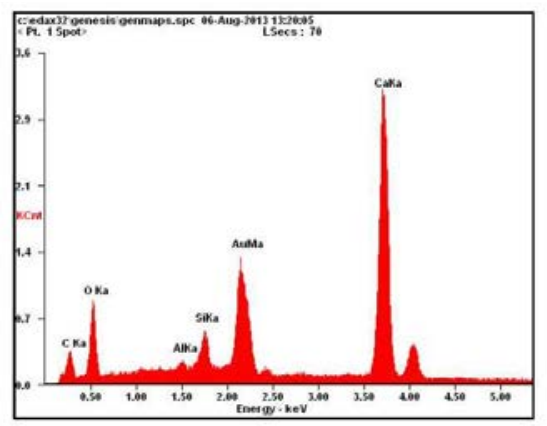

\begin{tabular}{|l|l|l|}
\hline Element & $\boldsymbol{W t} \%$ & $\boldsymbol{A t} \%$ \\
\hline CK & 09.37 & 21.96 \\
\hline OK & 26.46 & 46.52 \\
\hline AIK & 00.92 & 00.96 \\
\hline SiK & 02.85 & 02.85 \\
\hline AuM & 26.27 & 03.75 \\
\hline CaK & 34.13 & 23.96 \\
\hline Matrix & Correction & ZAF \\
\hline \hline
\end{tabular}

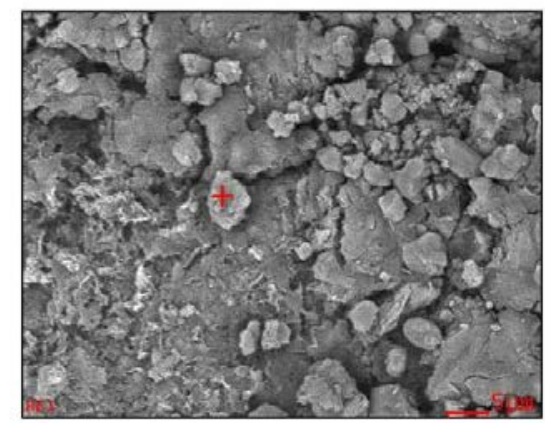

Figure 3.27. SEM/EDS analysis results for uranium-spiked granular sample, 1:1 solid-to-solution ratio conducted at $25^{\circ} \mathrm{C}$

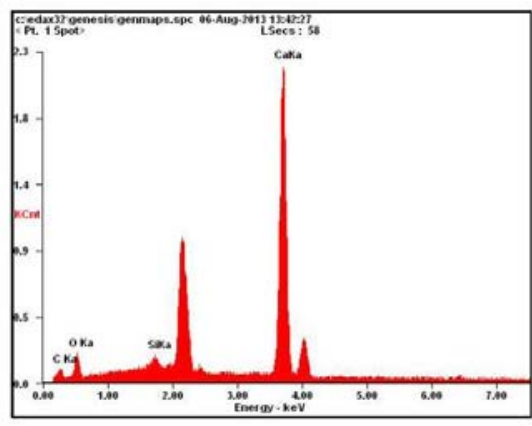

\begin{tabular}{|l|l|l|}
\hline Element & $\mathrm{Wt}^{\boldsymbol{\%}} \%$ & $\mathrm{At}^{\%} \%$ \\
\hline $\mathrm{CK}$ & 06.34 & 13.74 \\
\hline OK & 25.30 & 41.17 \\
\hline SiK & 02.47 & 02.29 \\
\hline $\mathrm{CaK}$ & 65.88 & 42.79 \\
\hline Matrix & Correction & ZAF \\
\hline \hline
\end{tabular}

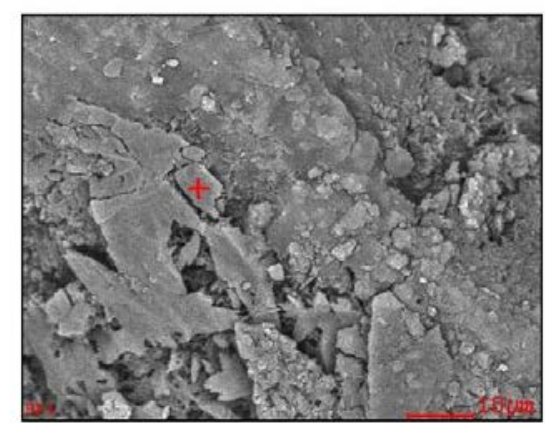

Figure 3.28. SEM/EDS analysis results for uranium-spiked granular sample, 1:1 solid-to-solution ratio conducted at $25^{\circ} \mathrm{C}$ 


\subsubsection{SEM/EDS Results for Uranium Granular Sample, 1:10 at $25^{\circ} \mathrm{C}$}

Images and SEM/EDS results for the uranium-spiked granular sample, 1:10 solid-to-solution ratio, at $25^{\circ} \mathrm{C}$, are provided in this section.
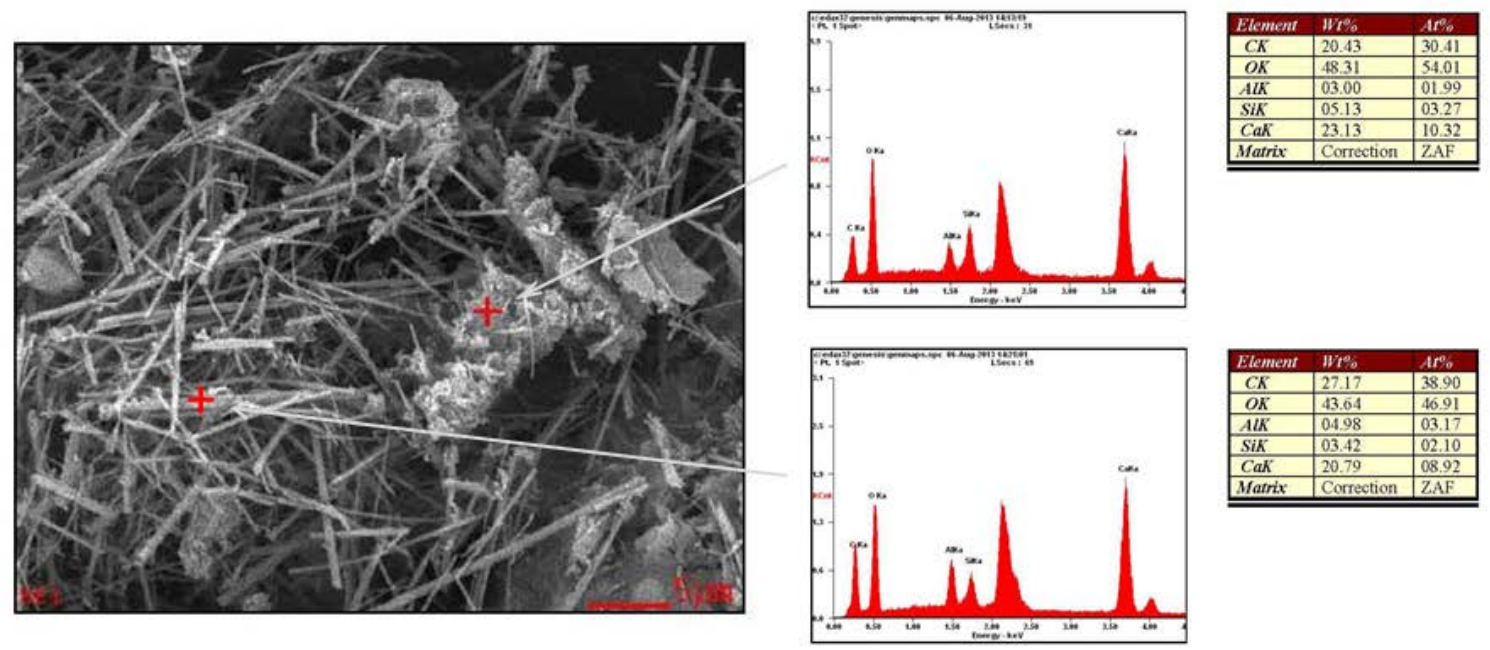

Figure 3.29. SEM/EDS analysis results for uranium-spiked granular sample, 1:10 solid-to-solution ratio conducted at $25^{\circ} \mathrm{C}$
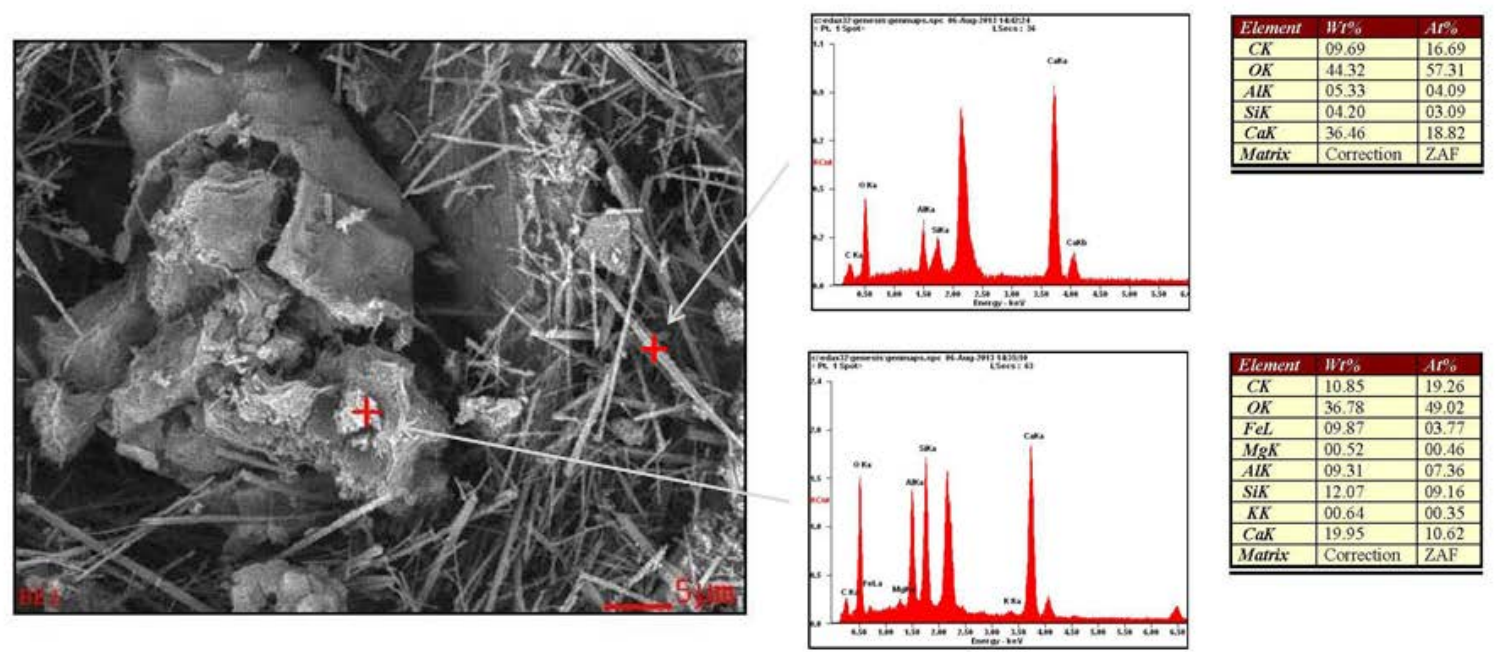

Figure 3.30. SEM/EDS analysis results for uranium-spiked granular sample, 1:10 solid-to-solution ratio conducted at $25^{\circ} \mathrm{C}$ 


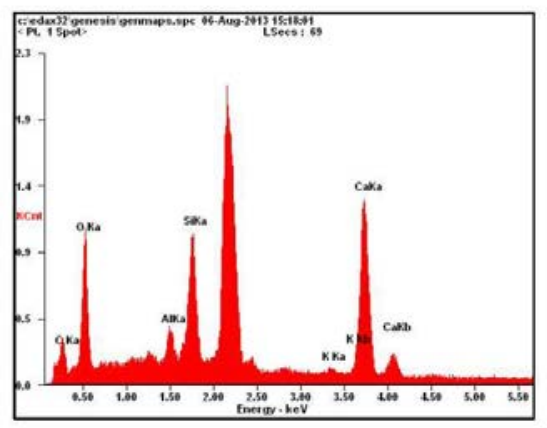

\begin{tabular}{|c|c|c|}
\hline Element & $W t^{\sigma} \%$ & $A t^{\%} \%$ \\
\hline$C K$ & 16.32 & 25.63 \\
\hline$O K$ & 45.37 & 53.50 \\
\hline$A L K$ & 02.58 & 01.80 \\
\hline SiK & 11.15 & 07.49 \\
\hline$K K$ & 00.70 & 00.34 \\
\hline $\mathrm{CaK}$ & 23.89 & 11.25 \\
\hline Matrix & Correction & $\mathrm{ZAF}$ \\
\hline
\end{tabular}

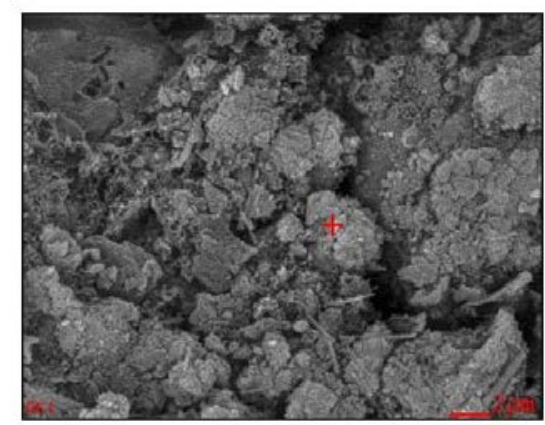

Figure 3.31. SEM/EDS analysis results for uranium-spiked granular sample, 1:10 solid-to-solution ratio conducted at $25^{\circ} \mathrm{C}$

\subsubsection{SEM/EDS Results for Uranium-spiked Monolith sample, 1:1 at $25^{\circ} \mathrm{C}$}

Images and SEM/EDS results for the uranium-spiked monolith sample, 1:1 solid-to-solution ratio, at $25^{\circ} \mathrm{C}$, are provided in this section. 


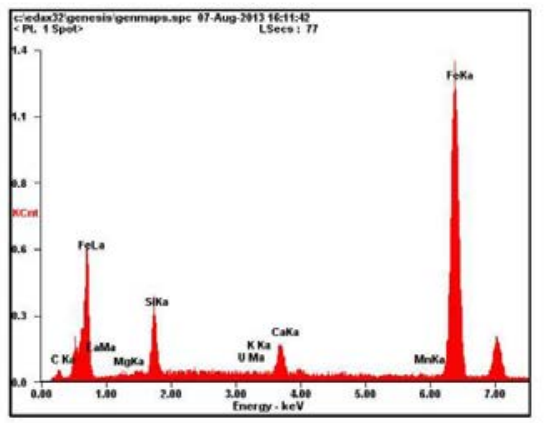

\begin{tabular}{|l|l|l|}
\hline Element & $\boldsymbol{W r} \%$ & $\mathrm{At} \%$ \\
\hline $\mathrm{CK}$ & 04.71 & 18.54 \\
\hline $\mathrm{LaM}$ & 11.82 & 04.03 \\
\hline $\mathrm{MgK}$ & 00.88 & 01.70 \\
\hline $\mathrm{SiK}$ & 06.54 & 11.02 \\
\hline $\mathrm{UM}$ & 01.08 & 00.21 \\
\hline $\mathrm{KK}$ & 00.18 & 00.22 \\
\hline $\mathrm{CaK}$ & 02.72 & 03.21 \\
\hline $\mathrm{MnK}$ & 00.76 & 00.65 \\
\hline FeK & 71.31 & 60.41 \\
\hline Matrix & Correction & ZAF \\
\hline \hline
\end{tabular}

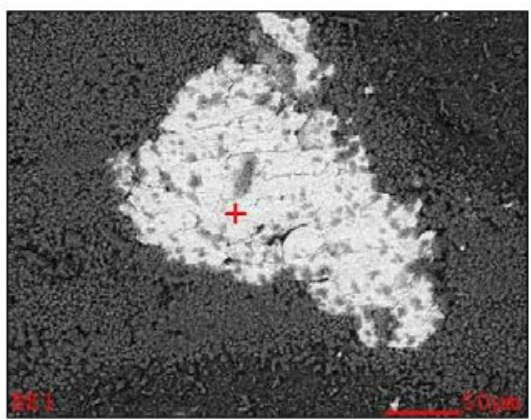

Figure 3.32. SEM/EDS analysis results for uranium-spiked monolith sample, 1:1 solid-to-solution ratio conducted at $25^{\circ} \mathrm{C}$

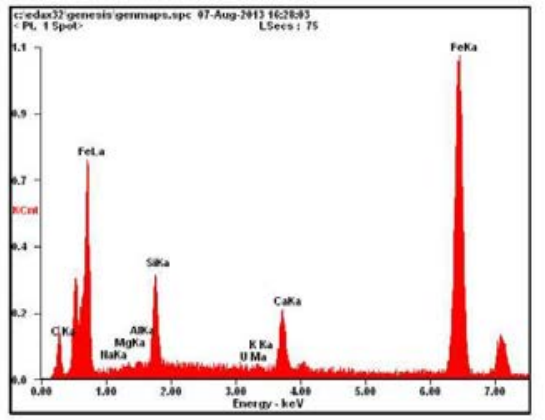

\begin{tabular}{|l|l|l|}
\hline Element & $W t^{\circ} \%$ & $A t^{\%}$ \\
\hline$C K$ & 16.99 & 46.06 \\
\hline NaK & 00.52 & 00.74 \\
\hline$M g K$ & 00.18 & 00.24 \\
\hline$A l K$ & 00.36 & 00.43 \\
\hline SiK & 06.61 & 07.66 \\
\hline$U M$ & 00.45 & 00.06 \\
\hline KK & 00.31 & 00.26 \\
\hline CaK & 04.66 & 03.78 \\
\hline FeK & 69.93 & 40.77 \\
\hline Matrix & Correction & ZAF \\
\hline \hline
\end{tabular}

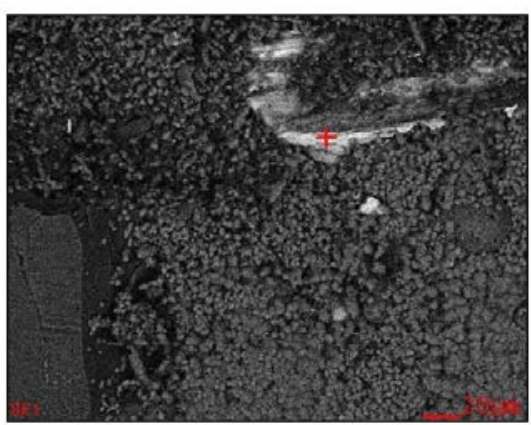


Figure 3.33. SEM/EDS analysis results for uranium-spiked monolith sample, 1:1 solid-to-solution ratio conducted at $25^{\circ} \mathrm{C}$
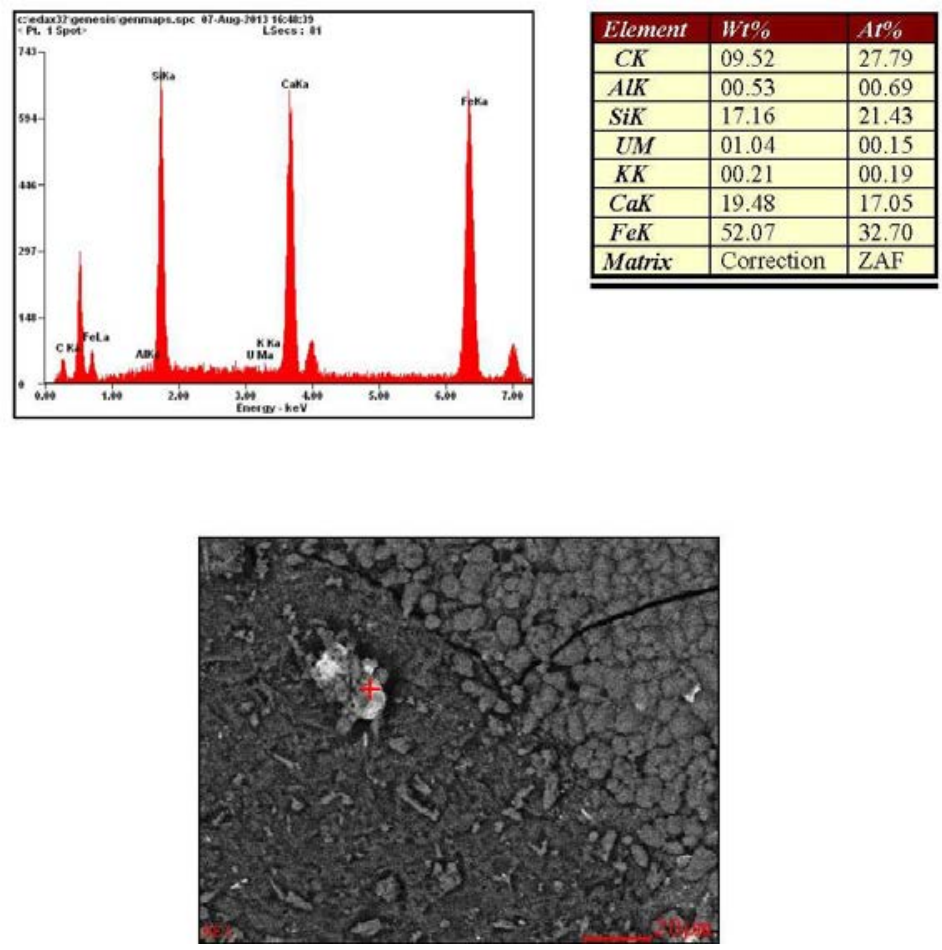

Figure 3.34. SEM/EDS analysis results for uranium-spiked monolith sample, 1:1 solid-to-solution ratio conducted at $25^{\circ} \mathrm{C}$

\subsubsection{SEM/EDS Results for Uranium-spiked Monolith sample, 1:10 at $25^{\circ} \mathrm{C}$}

Images and SEM/EDS results for the uranium-spiked monolith sample, 1:10 solid-to-solution ratio, at $25^{\circ} \mathrm{C}$, are provided in this section. 

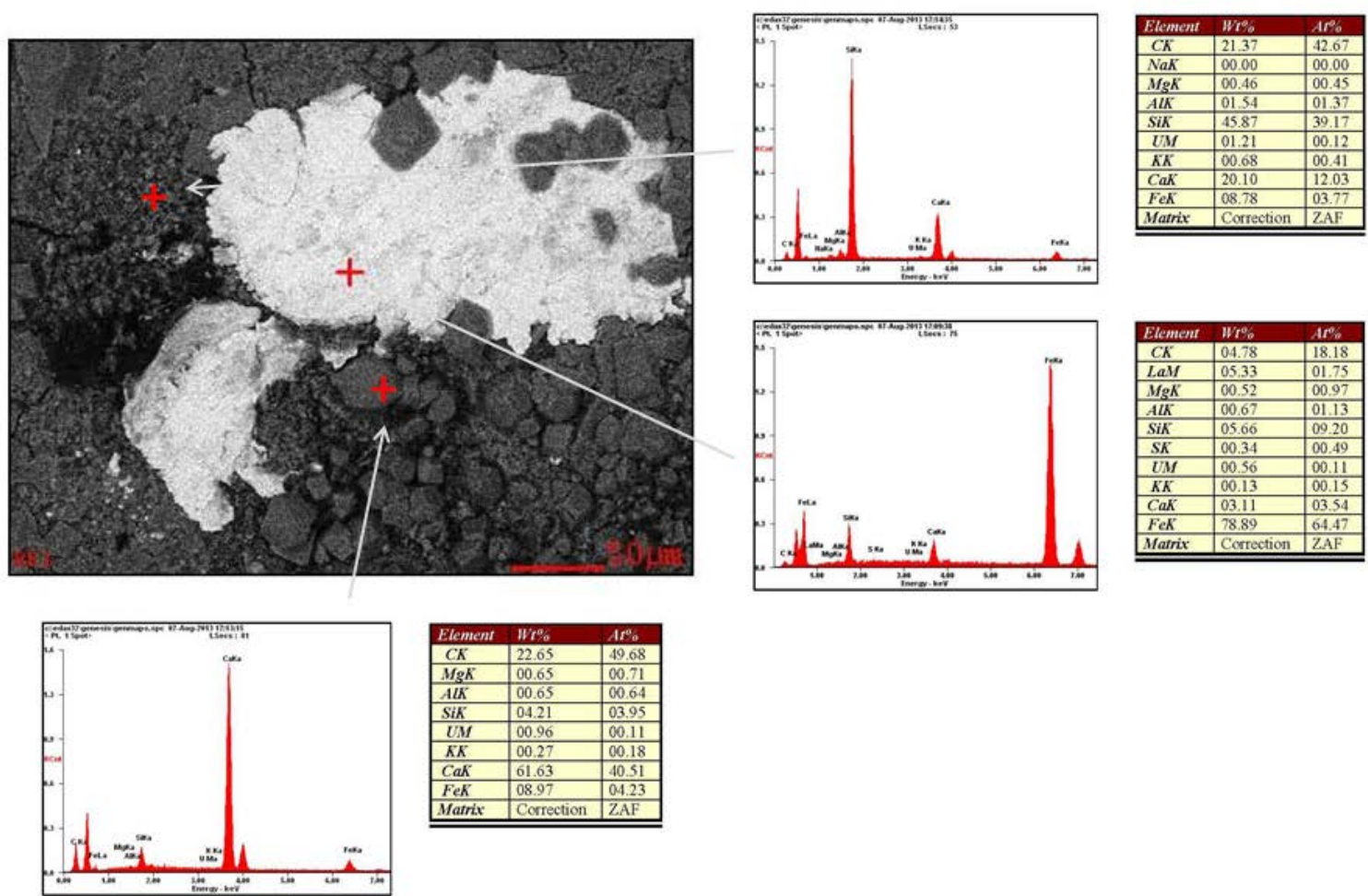

Figure 3.35. SEM/EDS analysis results for uranium-spiked monolith sample, 1:10 solid-to-solution ratio conducted at $25^{\circ} \mathrm{C}$ 


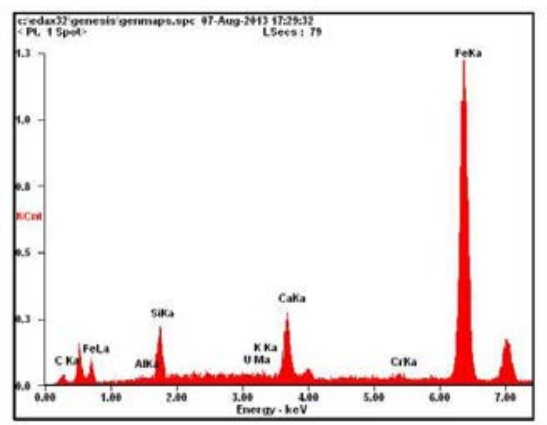

\begin{tabular}{|l|l|l|}
\hline Element & $W t^{\%}$ & $A t^{\%}$ \\
\hline$C K$ & 04.39 & 16.64 \\
\hline$A I K$ & 00.35 & 00.59 \\
\hline$S i K$ & 04.70 & 07.62 \\
\hline$U M$ & 01.17 & 00.22 \\
\hline$K K$ & 00.20 & 00.23 \\
\hline$C a K$ & 05.81 & 06.61 \\
\hline$C r K$ & 01.17 & 01.03 \\
\hline FeK & 82.22 & 67.07 \\
\hline Matrix & Correction & ZAF \\
\hline
\end{tabular}

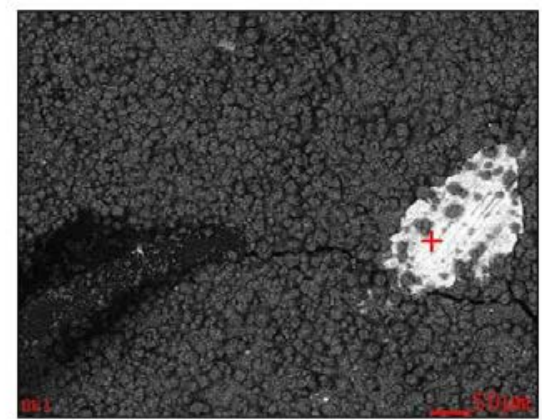

Figure 3.36. SEM/EDS analysis results for uranium-spiked monolith sample, 1:10 solid-to-solution ratio conducted at $25^{\circ} \mathrm{C}$ 


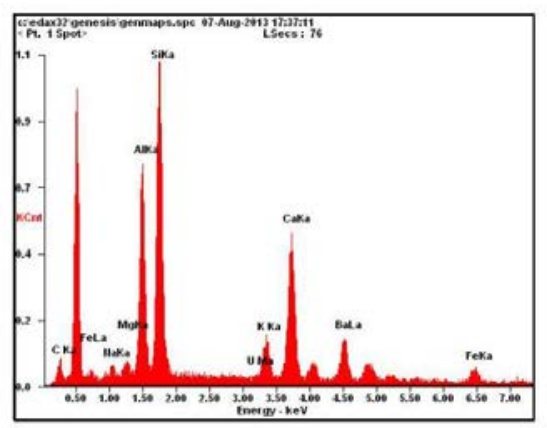

\begin{tabular}{|l|l|l|}
\hline Element & Wi $\%$ & $A t \%$ \\
\hline$C K$ & 16.37 & 37.63 \\
\hline NaK & 00.97 & 01.17 \\
\hline$M g K$ & 01.13 & 01.29 \\
\hline AlK & 14.82 & 15.17 \\
\hline SiK & 27.32 & 26.87 \\
\hline$U M$ & 00.57 & 00.07 \\
\hline KK & 03.69 & 02.61 \\
\hline CaK & 14.06 & 09.69 \\
\hline BaL & 16.71 & 03.36 \\
\hline FeK & 04.35 & 02.15 \\
\hline Matrix & Correction & ZAF \\
\hline \hline
\end{tabular}

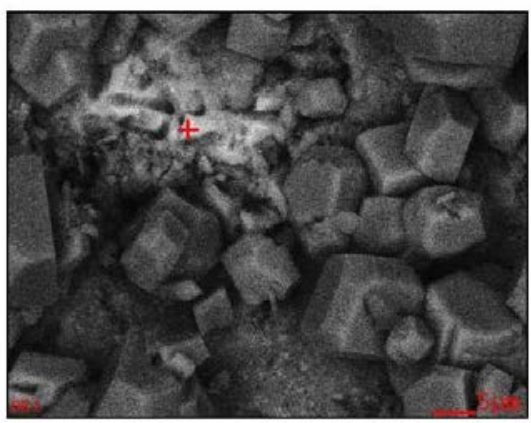

Figure 3.37. SEM/EDS analysis results for uranium-spiked monolith sample, 1:10 solid-to-solution ratio conducted at $25^{\circ} \mathrm{C}$

\subsubsection{SEM/EDS Results for Uranium-spiked Granular Sample, 1:1 at $60^{\circ} \mathrm{C}$}

Images and SEM/EDS results for the uranium-spiked granular sample, 1:1 solid-to-solution ratio, at $60^{\circ} \mathrm{C}$, are provided in this section. 

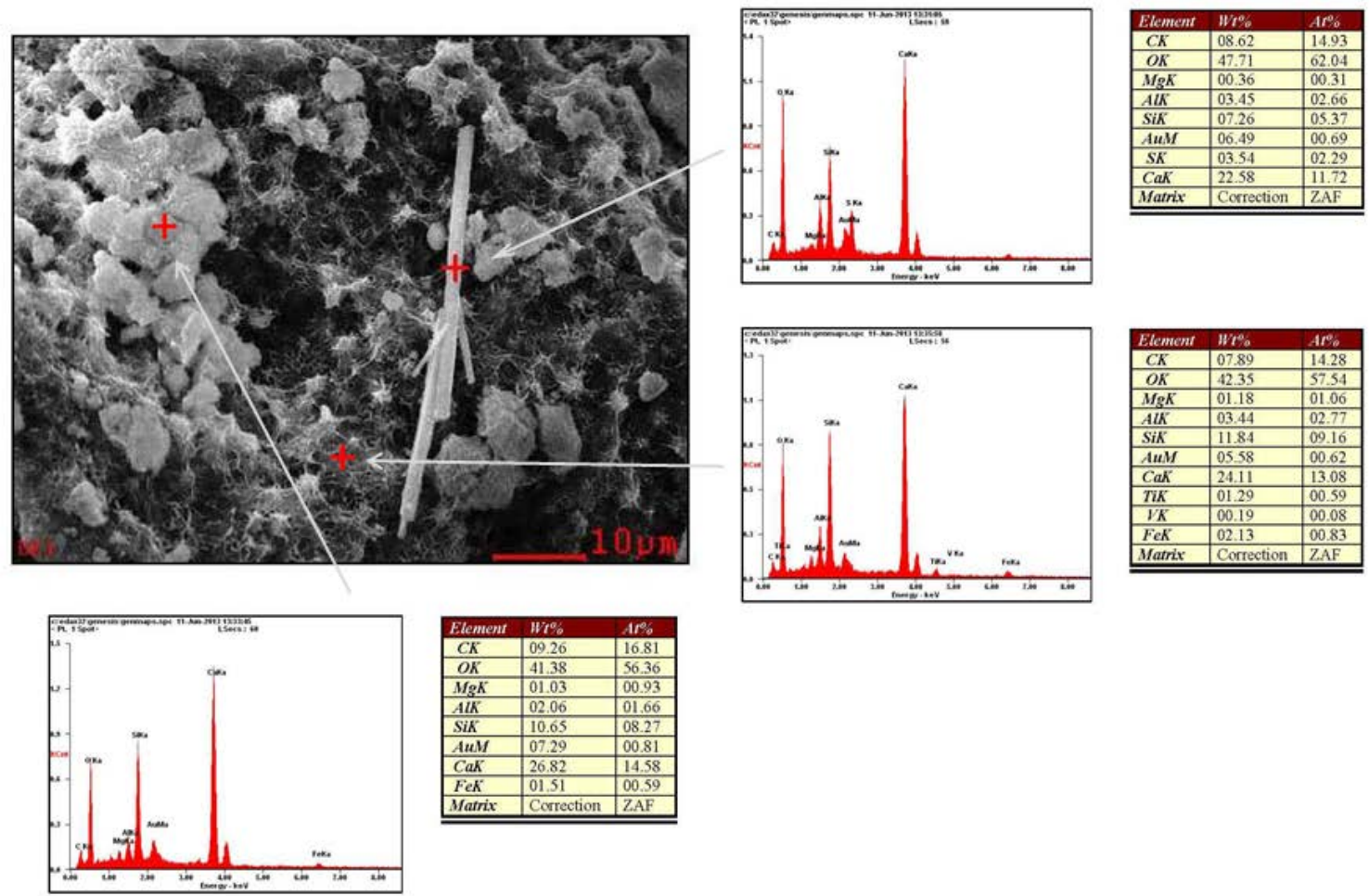

Figure 3.38. SEM/EDS analysis results for uranium-spiked granular sample, 1:1 solid-to-solution ratio conducted at $60^{\circ} \mathrm{C}$

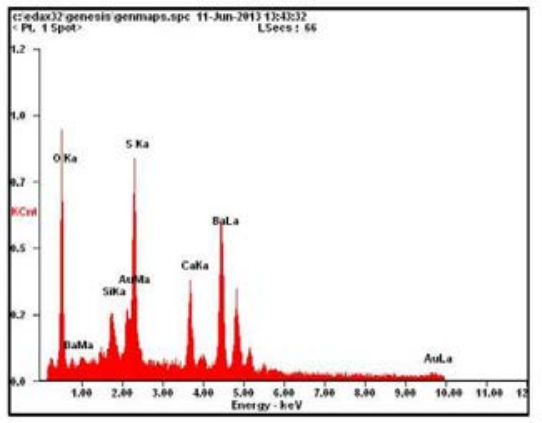

\begin{tabular}{|l|l|l|}
\hline Element & $W r^{\%}$ & $A r \%$ \\
\hline OK & 26.18 & 62.59 \\
\hline SiK & 03.30 & 04.50 \\
\hline SK & 11.35 & 13.54 \\
\hline CaK & 05.83 & 05.56 \\
\hline BaL & 40.94 & 11.40 \\
\hline AuL & 12.40 & 02.41 \\
\hline Matrix & Correction & ZAF \\
\hline \hline
\end{tabular}

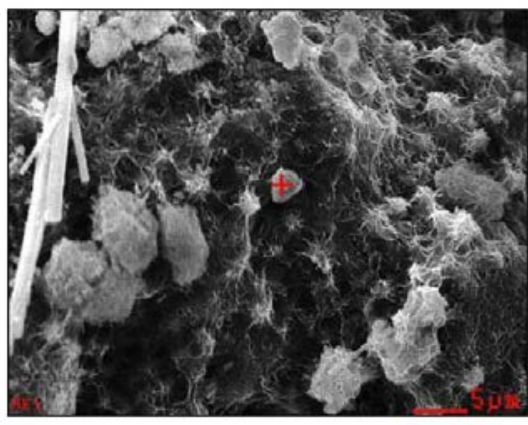

Figure 3.39. SEM/EDS analysis results for uranium-spiked granular sample, 1:1 solid-to-solution ratio conducted at $60^{\circ} \mathrm{C}$ 


\subsubsection{SEM/EDS Results for Uranium-spiked Granular Sample, 1:10 at $60^{\circ} \mathrm{C}$}

Images and SEM/EDS results for the uranium-spiked granular sample, 1:10 solid-to-solution ratio, at $60^{\circ} \mathrm{C}$, are provided in this section.
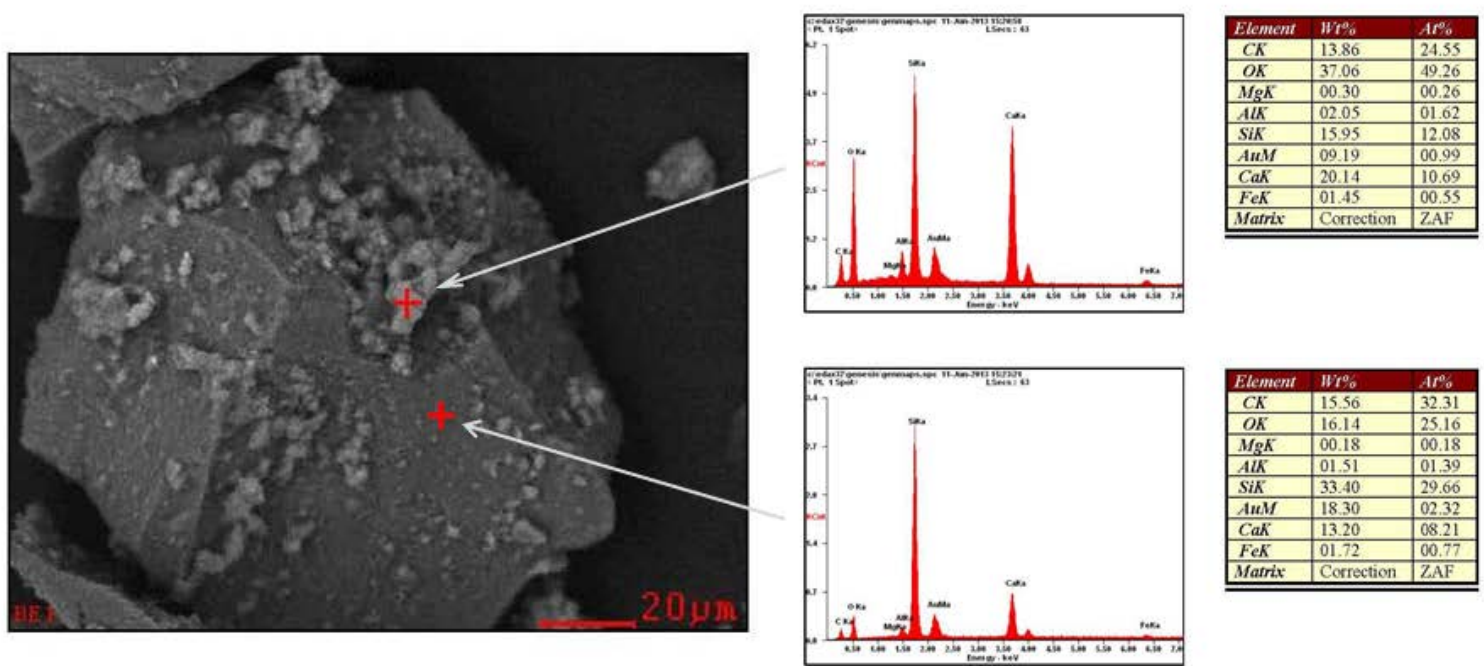

Figure 3.40. SEM/EDS analysis results for uranium-spiked granular sample, 1:10 solid-to-solution ratio conducted at $60^{\circ} \mathrm{C}$
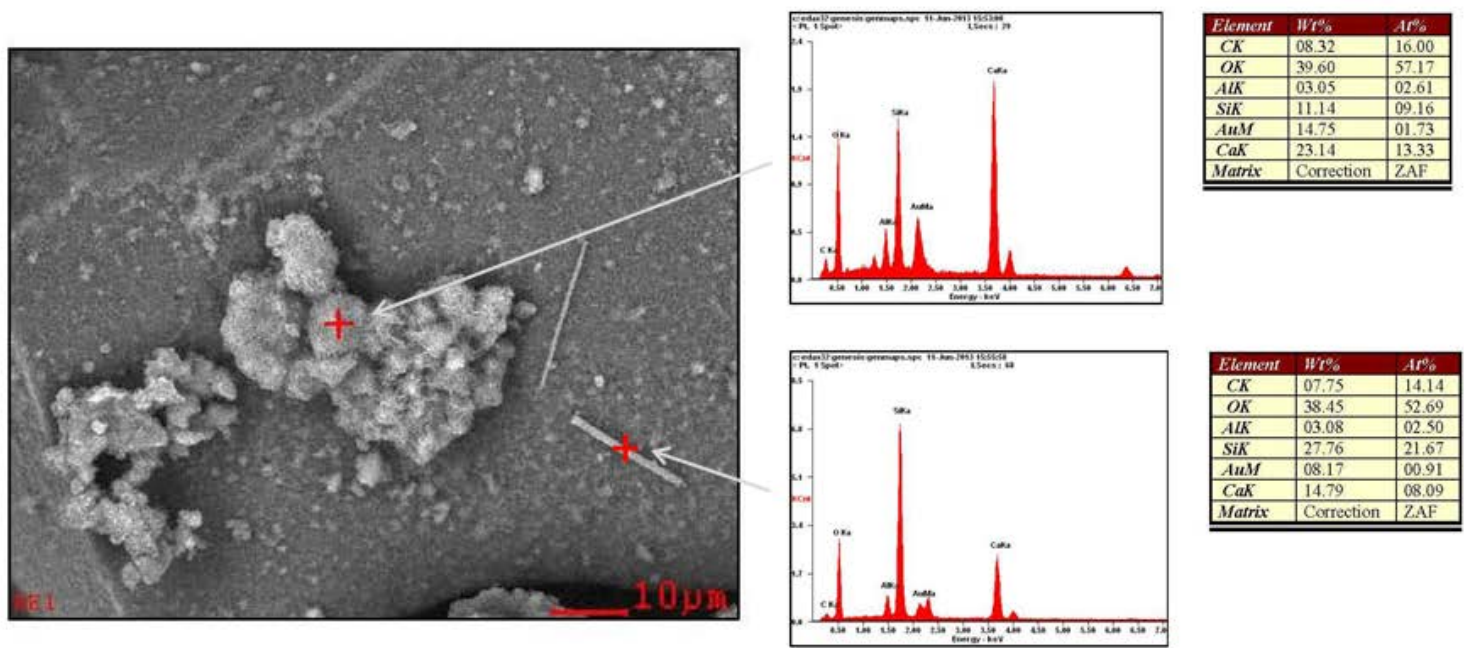

Figure 3.41. SEM/EDS analysis results for uranium-spiked granular sample, 1:10 solid-to-solution ratio conducted at $60^{\circ} \mathrm{C}$ 


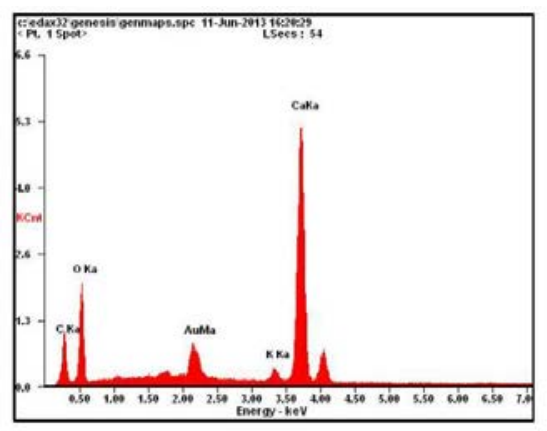

\begin{tabular}{|l|l|l|}
\hline Element & $W t^{\circ} \%$ & $A t \%$ \\
\hline$C K$ & 14.88 & 26.67 \\
\hline$O K$ & 39.19 & 52.72 \\
\hline$A u M$ & 09.54 & 01.04 \\
\hline$K K$ & 01.55 & 00.85 \\
\hline$C a K$ & 34.84 & 18.71 \\
\hline Matrix & Correction & ZAF \\
\hline \hline
\end{tabular}

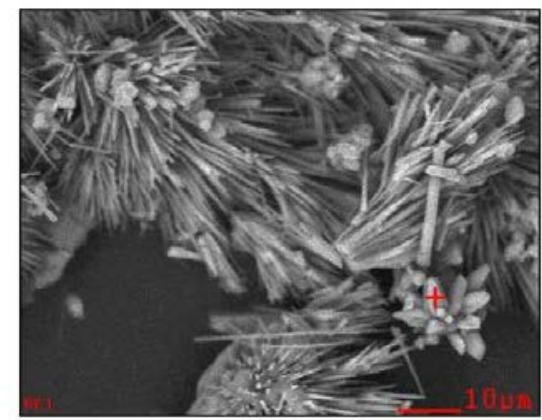

Figure 3.42. SEM/EDS analysis results for uranium-spiked granular sample, 1:10 solid-to-solution ratio conducted at $60^{\circ} \mathrm{C}$,

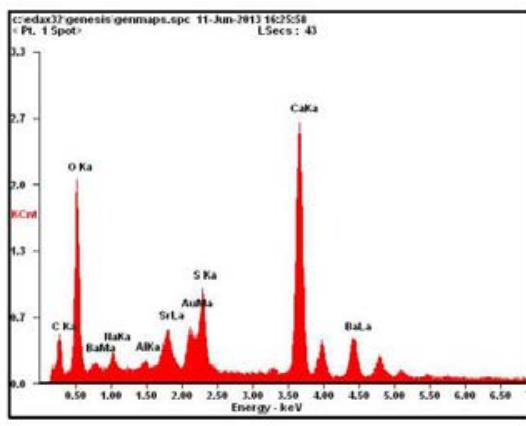

\begin{tabular}{|l|l|l|}
\hline Element & $\mathbf{W t} \%$ & $\mathbf{A t} \%$ \\
\hline$C K$ & 11.67 & 24.32 \\
\hline$O K$ & 34.03 & 53.23 \\
\hline$N a K$ & 01.52 & 01.65 \\
\hline$A l K$ & 00.44 & 00.40 \\
\hline$S r L$ & 04.39 & 01.26 \\
\hline$S K$ & 04.60 & 03.59 \\
\hline$C a K$ & 18.80 & 11.74 \\
\hline BaL & 12.44 & 02.27 \\
\hline AuL & 12.12 & 01.54 \\
\hline Matrix & Correction & ZAF \\
\hline \hline
\end{tabular}

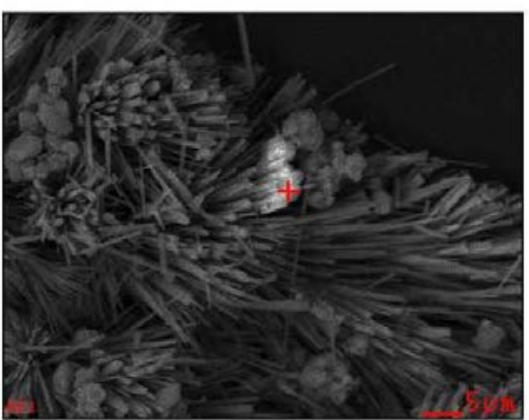

Figure 3.43. SEM/EDS analysis results for uranium-spiked granular sample, 1:10 solid-to-solution ratio conducted at $60^{\circ} \mathrm{C}$ 


\subsubsection{SEM/EDS Results for Uranium-spiked Monolith Sample, $1: 1$ at $60^{\circ} \mathrm{C}$}

Images and SEM/EDS results for the uranium-spiked monolith sample, 1:1 solid-to-solution ratio, at $60^{\circ} \mathrm{C}$, are provided in this section.
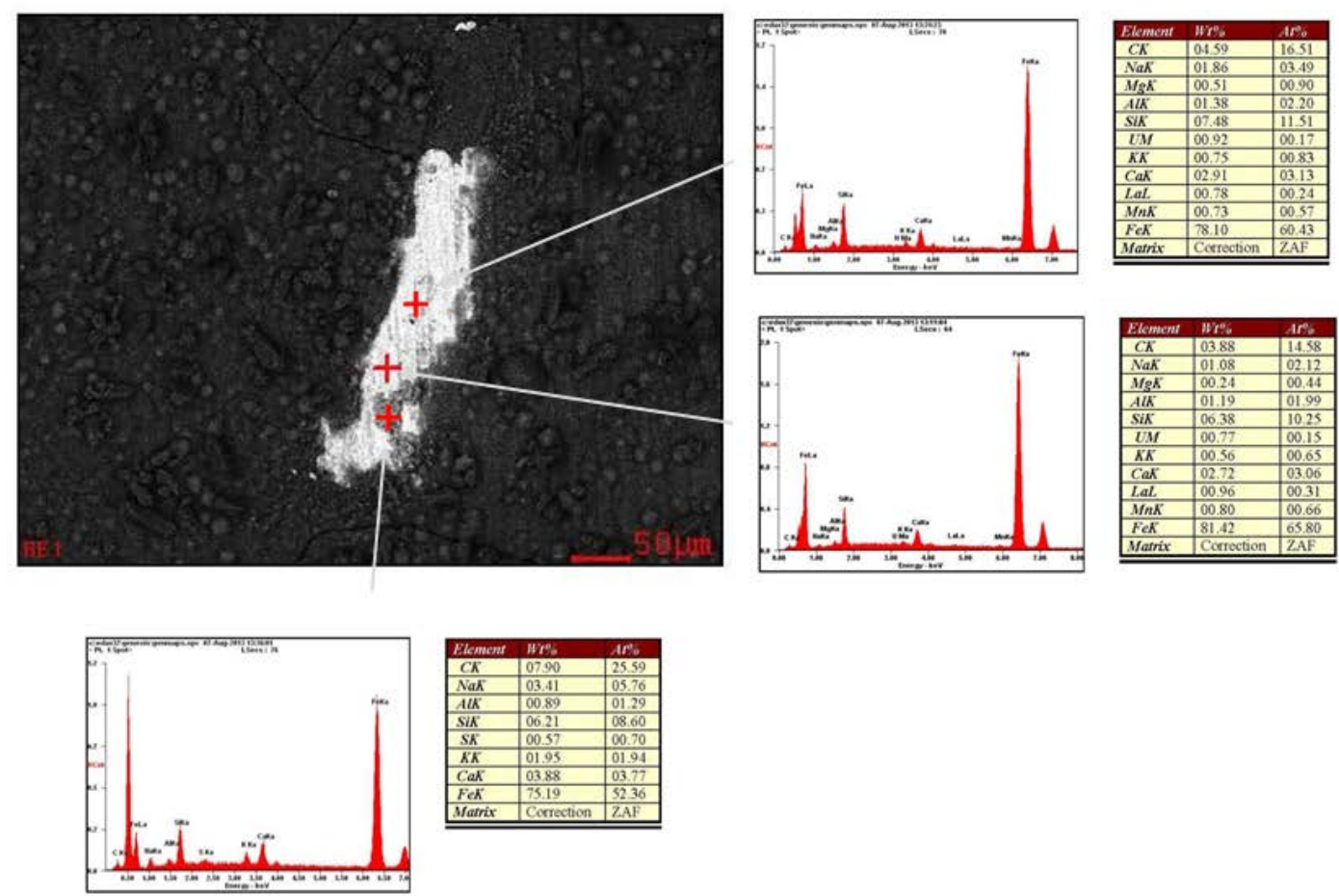

Figure 3.44. SEM/EDS analysis results for uranium-spiked monolith sample, 1:1 solid-to-solution ratio conducted at $60^{\circ} \mathrm{C}$ 


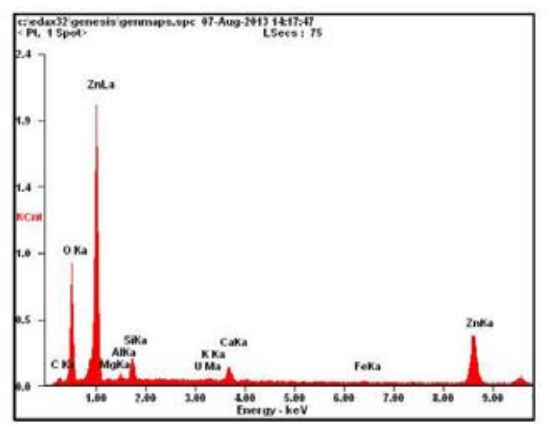

\begin{tabular}{|l|l|l|}
\hline Element & $\mathbf{W} \%$ & $\mathrm{At} \%$ \\
\hline $\mathrm{CK}$ & 05.20 & 12.06 \\
\hline $\mathrm{OK}$ & 33.04 & 57.51 \\
\hline $\mathrm{MgK}$ & 00.57 & 00.65 \\
\hline $\mathrm{AlK}$ & 01.21 & 01.25 \\
\hline $\mathrm{SiK}$ & 04.17 & 04.14 \\
\hline $\mathrm{UM}$ & 00.81 & 00.09 \\
\hline $\mathrm{KK}$ & 00.39 & 00.28 \\
\hline $\mathrm{CaK}$ & 02.56 & 01.78 \\
\hline $\mathrm{FeK}$ & 00.75 & 00.38 \\
\hline ZnK & 51.29 & 21.85 \\
\hline Matrix & Correction & ZAF \\
\hline \hline
\end{tabular}

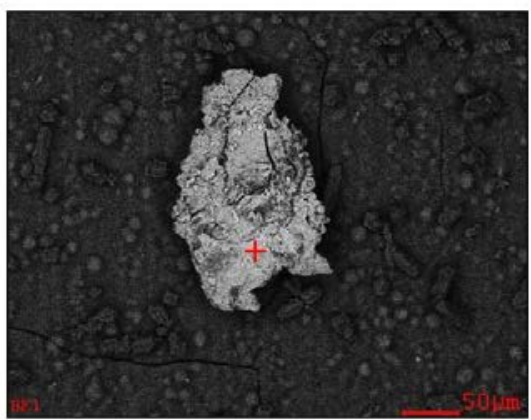

Figure 3.45. SEM/EDS analysis results for uranium-spiked monolith sample, 1:1 solid-to-solution ratio conducted at $60^{\circ} \mathrm{C}$
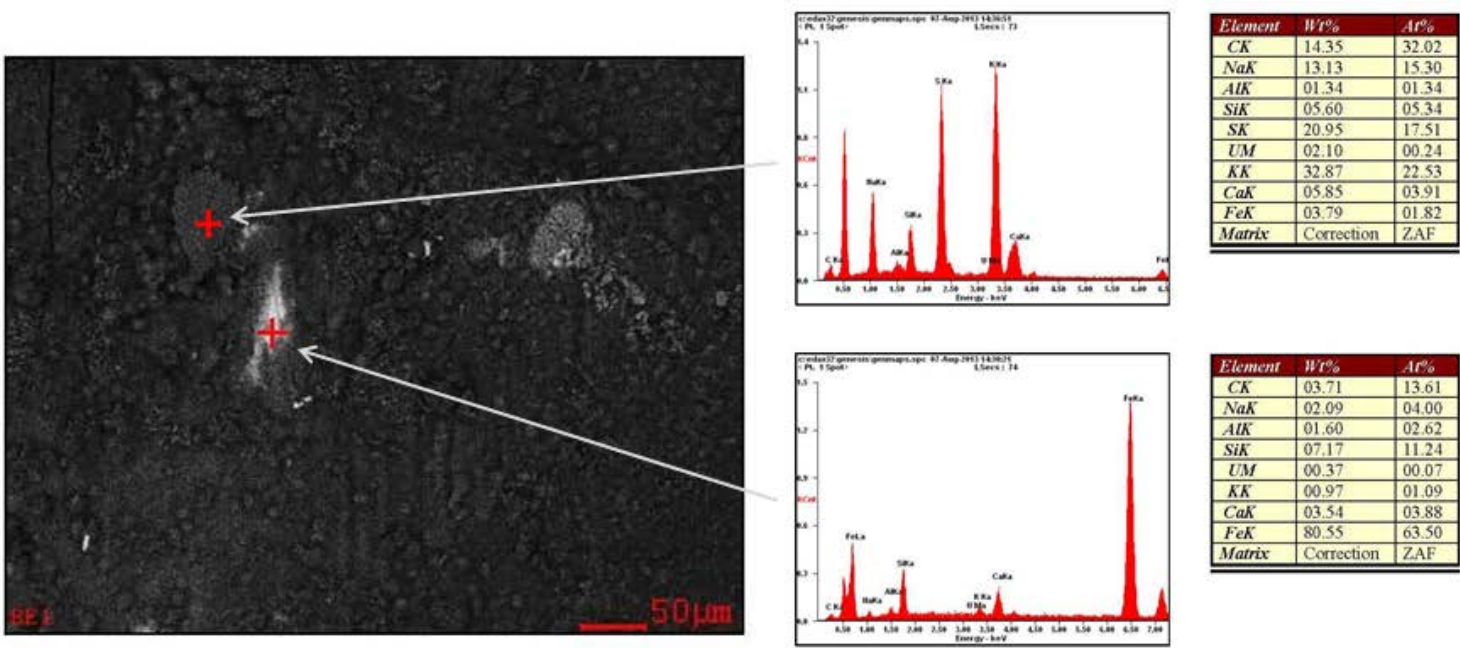

Figure 3.46. SEM/EDS analysis results for uranium-spiked monolith sample, 1:1 solid-to-solution ratio conducted at $60^{\circ} \mathrm{C}$

\subsubsection{SEM/EDS Results for Uranium-spiked Monolith Sample, 1:10 at $60^{\circ} \mathrm{C}$}

Images and SEM/EDS results for the uranium-spiked monolith sample, 1:10 solid-to-solution ratio, at $60^{\circ} \mathrm{C}$, are provided in this section. 

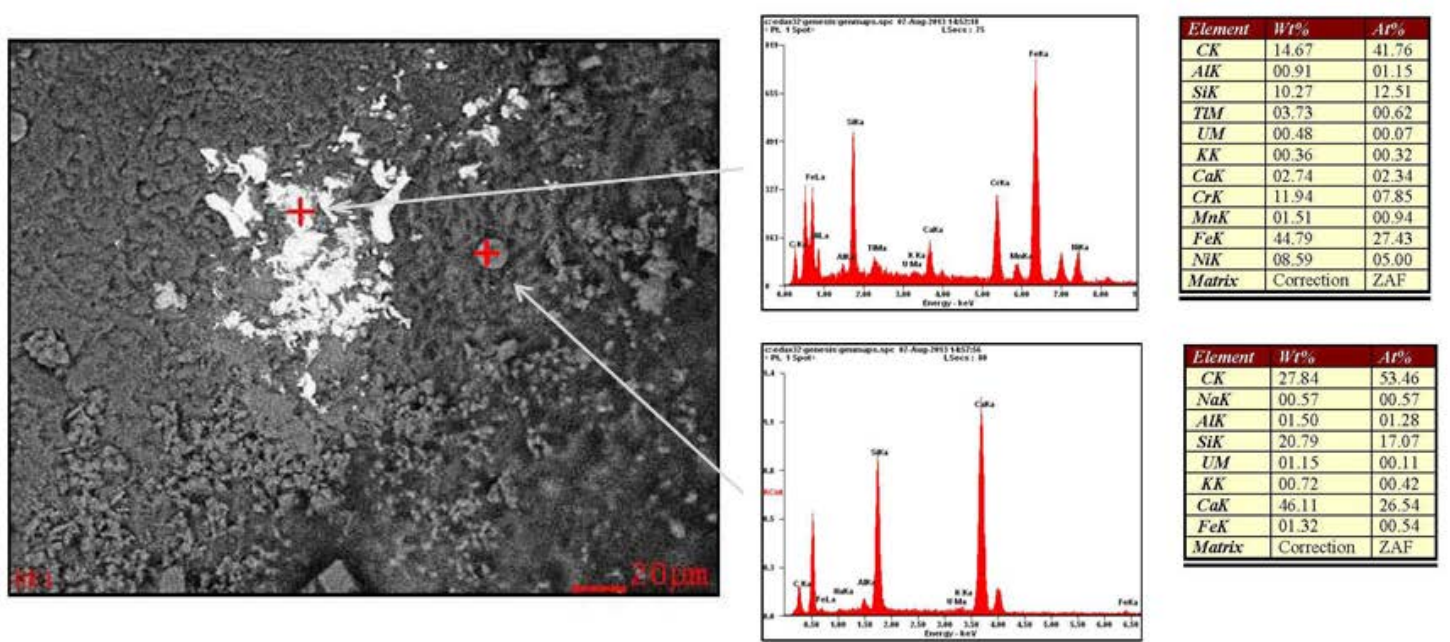

Figure 3.47. SEM/EDS analysis results for uranium-spiked monolith sample, 1:10 solid-to-solution ratio conducted at $60^{\circ} \mathrm{C}$
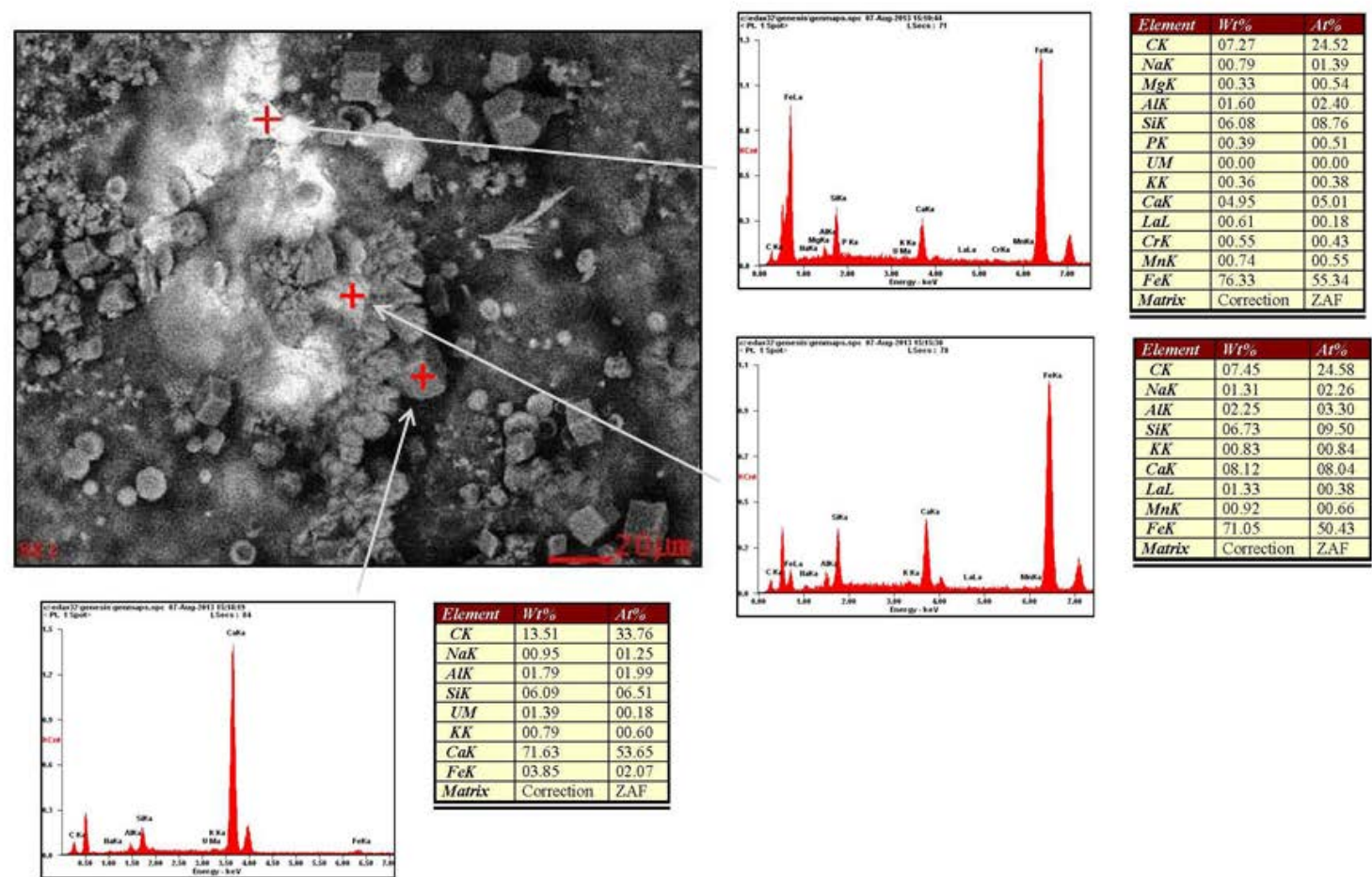

Figure 3.48. SEM/EDS analysis results for uranium-spiked monolith sample, 1:10 solid-to-solution ratio conducted at $60^{\circ} \mathrm{C}$ 

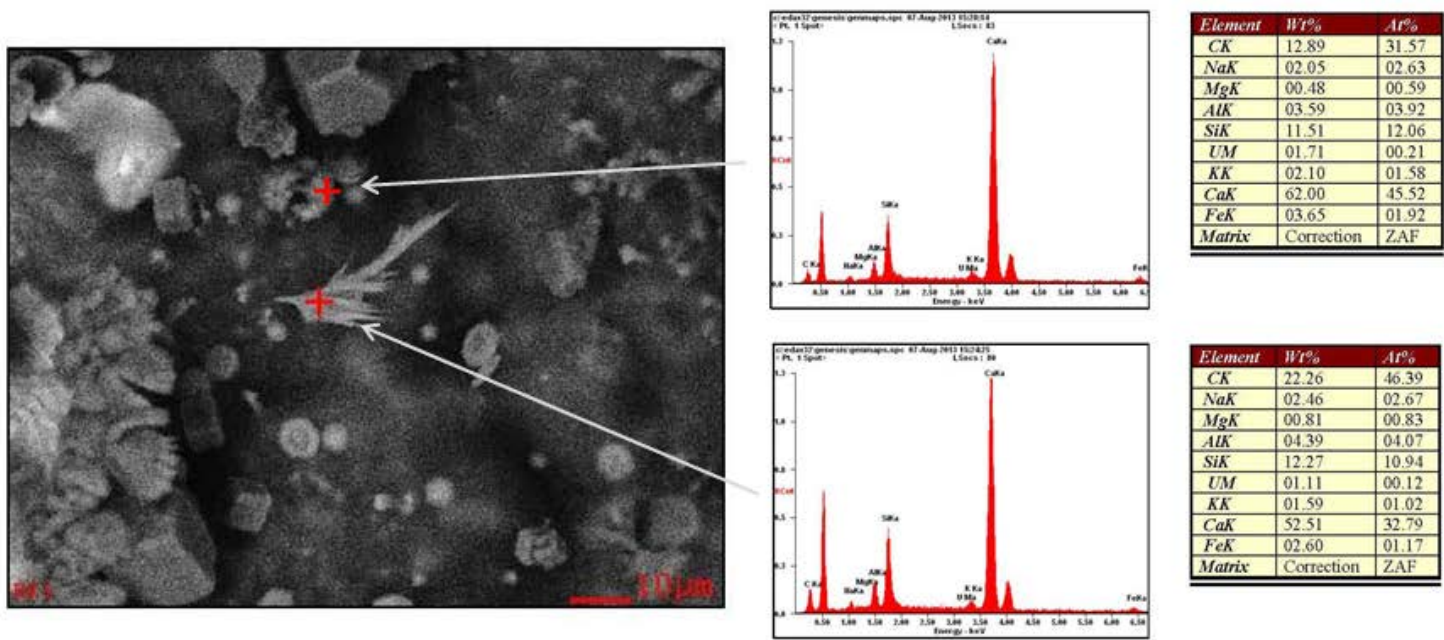

Figure 3.49. SEM/EDS analysis results for uranium-spiked monolith sample, 1:10 solid-to-solution ratio conducted at $60^{\circ} \mathrm{C}$
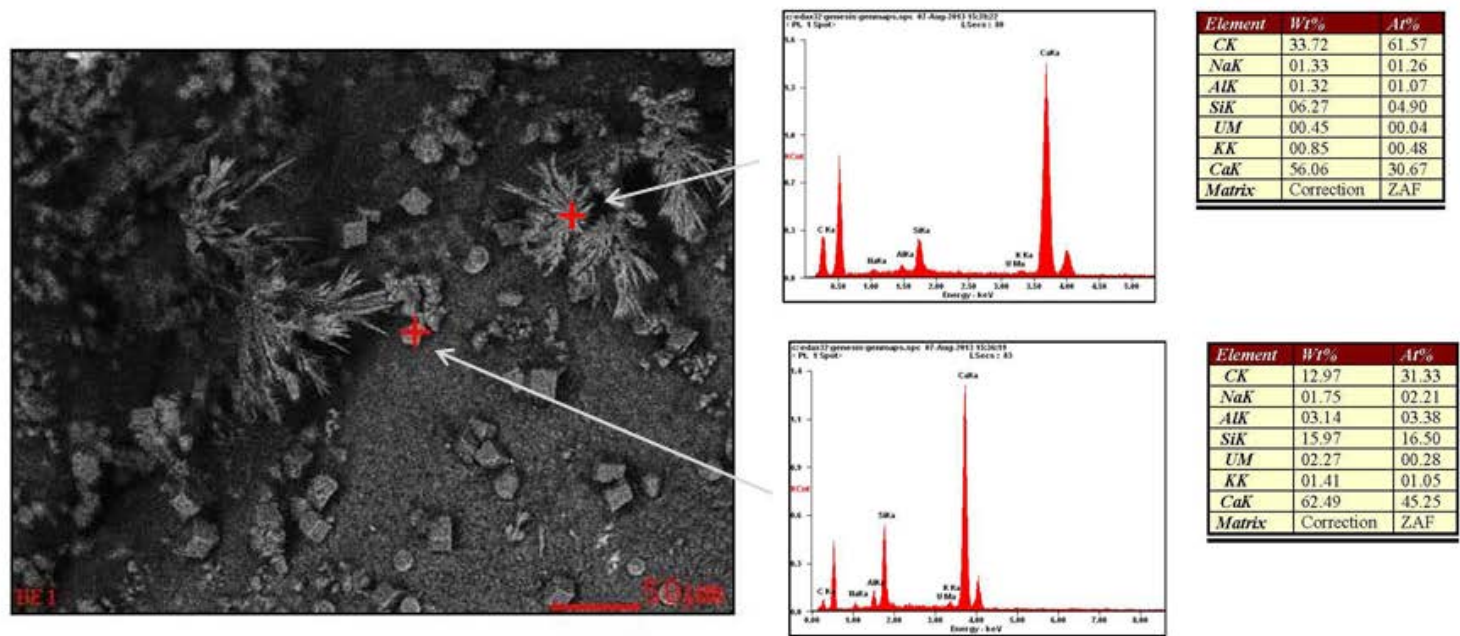

Figure 3.50. SEM/EDS analysis results for uranium-spiked monolith sample, 1:10 solid-to-solution ratio conducted at $60^{\circ} \mathrm{C}$ 


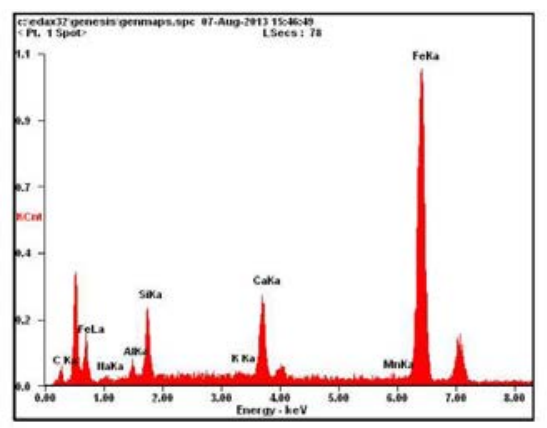

\begin{tabular}{|l|l|l|}
\hline Element & Wt\% & At\% \\
\hline$C K$ & 06.85 & 23.27 \\
\hline NaK & 01.02 & 01.80 \\
\hline$A l K$ & 01.51 & 02.29 \\
\hline SiK & 05.89 & 08.56 \\
\hline$K K$ & 00.55 & 00.57 \\
\hline $\mathrm{CaK}$ & 06.78 & 06.90 \\
\hline $\mathrm{MnK}$ & 01.05 & 00.78 \\
\hline FeK & 76.36 & 55.82 \\
\hline Matrix & Correction & ZAF \\
\hline \hline
\end{tabular}

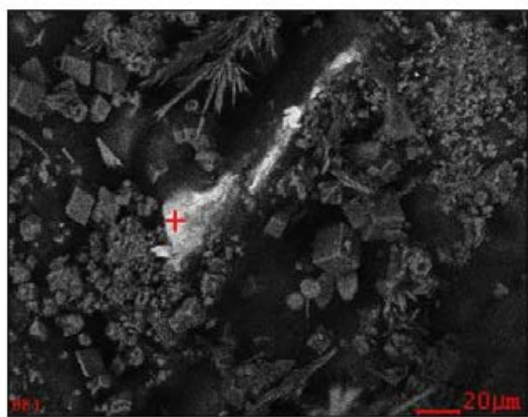

Figure 3.51. SEM/EDS analysis results for uranium-spiked monolith sample, 1:10 solid-to-solution ratio conducted at $60^{\circ} \mathrm{C}$

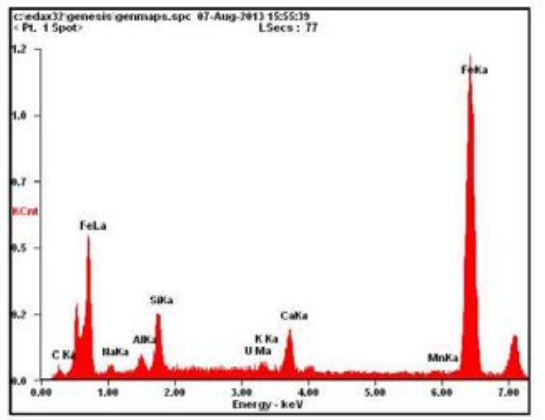

\begin{tabular}{|l|l|l|}
\hline Element & Wi $\%$ & $A t^{\%}$ \\
\hline$C K$ & 05.86 & 20.21 \\
\hline NaK & 02.91 & 05.24 \\
\hline$A I K$ & 02.41 & 03.70 \\
\hline SiK & 06.29 & 09.27 \\
\hline$U M$ & 01.58 & 00.28 \\
\hline$K K$ & 00.73 & 00.77 \\
\hline CaK & 03.56 & 03.68 \\
\hline MnK & 01.11 & 00.84 \\
\hline FeK & 75.55 & 56.02 \\
\hline Matrix & Correction & ZAF \\
\hline \hline
\end{tabular}

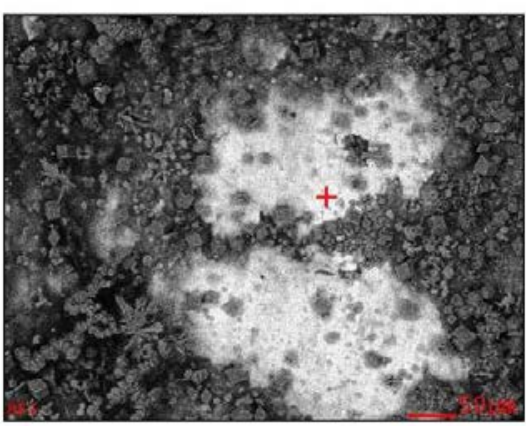

Figure 3.52. SEM/EDS analysis results for uranium-spiked monolith sample, 1:10 solid-to-solution ratio conducted at $60^{\circ} \mathrm{C}$ 


\subsection{Uranium-Spiked Sample Results and Discussion}

Uranium will often react with carbon dioxide and form different uranyl-carbonate complexes including soddyite, becquerelite, and uranophane. These secondary phases are important because these uranium-mineral phases can affect the long-term immobilization of uranium. Several of the SEM images show a crystalline needle-like structure (see Figure 3.29 and Figure 3.30) dominated by calcium and aluminum that could potentially be ettringite. In Figure 3.42 both the needle-like structure as well as some more blocky, tabular crystals are visible. The tabular crystals may be the mineral becquerelite. The formation of becquerelite was confirmed to be a secondary phase found in previous concrete waste form studies (Wellman, Mattigod et al. 2007, Wellman, Bovaird et al. 2008). In Figure 3.37, a cubic structured crystalline phase that is high in barium and sulfur is visible on the SEM scan of the $25^{\circ} \mathrm{C} 1: 10$ monolith sample. The source of the barium is from the fly ash. The different monolith SEM images show both crystalline and amorphous secondary phases. Several of the amorphous phases are dominated primarily by iron. Most of the amorphous phases shown in the monolith sample SEM images also show the presence of uranium confirming that formation of the secondary phases are encompassing the uranium in the structures.

The PCT data for the uranium-spiked concrete is similar to the technetium data. The normalized concentration of calcium is much higher than sodium, suggesting that the calcium may be sequestered in the formation of secondary phases.

XRD was not run on the uranium samples due to extensive studies already available from previous work. Please see Wellman, Mattigod et al. 2007 and Wellman, Bovaird et al. 2008.

\subsection{PUF}

PUF column tests continue to run and will be included in a later report. 


\subsection{Conclusions}

- The PCT results for both the technetium-spiked and uranium-spiked samples resulted in high normalized concentrations of sodium and lower concentrations of calcium, suggesting that the calcium is being sequestered in the formation of secondary phases.

- The SEM images for the technetium and uranium-spiked granular samples show the formation of both crystalline and amorphous secondary phases.

- Specifically, the needle-like structure of what is likely ettringite is visible in SEM images from both the technetium and uranium-spiked samples. The presence of ettringite in the technetium-spiked sample was confirmed by XRD scans.

- The XRD scans of the technetium-spiked granular samples for both temperatures have quartz and calcite in common, but the presence of different minerals at the $25^{\circ} \mathrm{C}$ versus the $60^{\circ} \mathrm{C}$ samples show the formation of secondary phases that are dependent on temperature. The different solid-to-solution volume ratio, however, did not have any effect on the mineral formation. 



\subsection{References}

ASTM. 1994. Standard Test Methods for Determining Chemical Durability of Nuclear Waste Glasses: The Product Consistency Test (PCT). ASTM International, West Conshohcken, PA.

DOE Order 435.1. Radioactive Waste Management. U.S. Department of Energy, Washington, DC.

Mann FM et al. 2000. Hanford Immobilized Low-Activity Waste Performance Assessment: 2001

Version. Pacific Northwest National Laboratory, Richland, Washington.

McGrail BP, PFC Martin, and CW Lindenmeier. 1997. "Accelerated testing of waste forms using a novel Pressurized Unsaturated Flow (PUF) method.” In Materials Research Society Symposium Proceedings.

McGrail BP, PFC Martin, and CW Lindenmeier. 1999. "Method and apparatus for measuring coupled flow, transport, and reaction processes under liquid unsaturated flow conditions.” In Battelle Memorial Institute.

McGrail PB et al. 1998. A strategy to conduct an analysis of the long-term performance of low-activity waste glass in a shallow subsurface disposal system at Hanford. Pacific Northwest National Laboratory, Richland, Washington.

McGrail PB et al. 2000. Low-activity waste glass studies: FY2000 summary report. Pacific Northwest National Laboratory, Richland, Washington.

Meyer PD and RJ Serne. 1999. Near-field hydrology data package for the immobilized low-activity waste 2001 performance assessment. Pacific Northwest National Laboratory, Richland, Washington.

Pierce EM et al. 2006. “The Accelerated Weathering of a Radioactive Low-Activity Waste Glass Under Hydraulically Unsaturated Conditions: Experimental Results from a Pressurized Unsaturated Flow (PUF) Test.” Nuclear Technology 155(2):149-155.

Richards LA. 1931. “Capillary Conduction of Liquids Through Porous Mediums.” Physics 1:318-333.

Serne RJ et al. 1989. Leach Tests on Grouts Made with Actual and Trace Metal-Spiked Synthetic Phosphate/Sulfate Waste. Pacific Northwest Laboratory, Richland, Washington.

Serne RJ et al. 1992a. Leach Testing of in Situ Stabilization Grouts Containing Additives to Sequester Contaminants. Pacific Northwest Laboratory, Richland, Washington.

Serne RJ et al. 1993. Solid-waste leach characterization and contaminant-sediment interactions. Pacific Northwest Laboratory, Richland, Washington.

Serne RJ, RO Lokken, and LJ Criscenti. 1992b. "Characterization of Grouted LLW to Support Performance Assessment.” Waste Management 12:271-287.

Serne RJ, WJ Martin, and VL LeGore. 1995. Leach Test of Cladding Removal Waste Grout Using Hanford Groundwater. Pacific Northwest Laboratory, Richland, Washington.

Wierenga PJ and MT Van Genuchten. 1989. “Solute transport through small and large unsaturated soil columns.” Ground water 27(1):35-42. 
Wierenga PJ et al. 1993. Soil characterization methods for unsaturated low-level waste sites. Pacific Northwest Laboratory, Richland, Washington. pp. 7-16.

Wellman, D. M., et al. (2008). Effect of Concrete Wasteform Properties on Radionuclide Migration. Richland, WA, Pacific Northwest National Laboratory.

Wellman, D. M., et al. (2007). "Experimental limitations regarding the formation and characterization of uranium-mineral phases in concrete waste forms." Cement and Concrete Research.

Wood MI et al. 1995. Performance Assessment for the Disposal of Low-Level Waste in the 218-W-5 Burial Ground. Westinghouse Hanford Company, Richland, Washington. 
PNNL-22880

\section{Distribution}

No. of

Copies

\# Sunil Mehta

(PDF)

Organization

Address

City, State and ZIP Code
No. of

\section{Copies}

$\begin{array}{ll}\text { \# } & \text { Local Distribution } \\ & \text { Pacific Northwest National Laboratory } \\ \text { Elizabeth Golovich } & \text { (PDF) } \\ \text { Dawn Wellman } & \text { (PDF) }\end{array}$






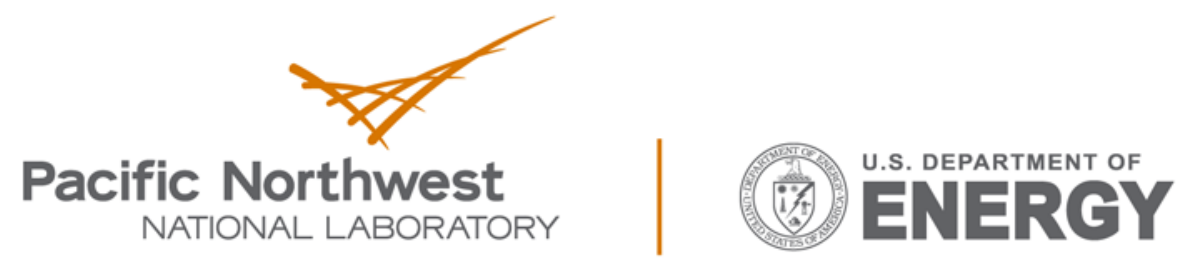

Proudly Operated by Battelle Since 1965

902 Battelle Boulevard

P.O. Box 999

Richland, WA 99352

1-888-375-PNNL (7665)

www.pnnl.gov 